FEDERAL RESERVE BANK OF SAN FRANCISCO

WORKING PAPER SERIES

\title{
Physician Competition and the Provision of Care: Evidence from Heart Attacks
}

\author{
Abe Dunn \\ Bureau of Economic Analysis \\ Adam Hale Shapiro \\ Federal Reserve Bank of San Francisco
}

May 2015

Working Paper 2015-07

http://www.frbsf.org/economic-research/publications/working-papers/wp2015-07.pdf

\section{Suggested citation:}

Dunn, Abe and Adam Hale Shapiro. 2015. "Physician Competition and the Provision of Care: Evidence from Heart Attacks.” Federal Reserve Bank of San Francisco Working Paper 2015-07. http://www.frbsf.org/economic-research/publications/working-papers/wp2015-07.pdf

The views in this paper are solely the responsibility of the authors and should not be interpreted as reflecting the views of the Federal Reserve Bank of San Francisco or the Board of Governors of the Federal Reserve System. 


\title{
Physician Competition and the Provision of Care: Evidence from Heart Attacks*
}

\author{
Abe Dunn ${ }^{\dagger}$ and Adam Hale Shapiro
}

May 15, 2015

\begin{abstract}
We study the impact of competition among physicians on service provision and patients' health outcomes. We focus on cardiologists treating patients with a firsttime heart attack treated in the emergency room. Physician concentration has a small, but statistically significant effect on service utilization. A one-standard deviation increase in cardiologist concentration causes a 5 percent increase in cardiologist service provision. Cardiologists in more concentrated markets perform more intensive procedures, particularly, diagnostic procedures - services in which the procedure choice is more discretionary. Higher concentration also leads to fewer readmissions, implying potential health benefits. These findings are potentially important for antitrust analysis and suggest that changes in organizational structure in a market, such as a merger of physician groups, not only influences the negotiated prices of services, but also service provision.
\end{abstract}

${ }^{*}$ The views expressed in the paper are those of the authors and not of the Federal Reserve System or the Federal Reserve Bank of San Francisco

${ }^{\dagger}$ Bureau of Economic Analysis. email: abe.dunn@bea.gov

${ }_{\ddagger}^{\ddagger}$ Corresponding Author: Federal Reserve Bank of San Francisco. email: adam.shapiro@sf.frb.org 


\section{Introduction}

Health care is a unique industry in terms of how consumers and firms interact. Consumers of health care (i.e., patients) do not observe the prices paid to physicians but rely on physicians to make consumption (i.e., diagnostic and treatment) decisions. Physicians not only provide care and make decisions for their patients but also negotiate with insurance firms over payment contracts. Evidence suggests a link between health-care provision and the financial incentives of physicians. ${ }^{1}$ In the commercial sector, where prices are shaped by competitive market forces, the same financial incentives are likely to influence diagnostic and treatment decisions. However, there is currently no documented evidence about how competition among physicians affects service use. ${ }^{2}$ Determining the interplay between market forces and health-care provision is therefore an important part of understanding how the health-care industry functions. Indeed, this relationship may be central to selecting optimal antitrust and regulatory policies that influence the structure of physician organizations.

In a previous study, we showed that higher market concentration is associated with higher negotiated service prices for physicians in the commercial sector (Dunn and Shapiro [2014]). ${ }^{3}$ This paper extends our analysis by examining how concentration impacts health services. Specifically, we assess how the competitive environment of physician firms affects both the quantity and type of health services provided to the patient. We also examine how it ultimately affects the health of the patient. Our estimation relies on a measure of physician market concentration called the "Fixed-Travel-Time Herfindahl-Hirshman index" (FTHHI). This measure was used in Dunn and Shapiro [2014] to assess the relationship between physician concentration and service prices. Similar to the measure of hospital competition used by Kessler and McClellan [2000], the FTHHI is based on theoretically predicted market shares. Thus, unlike typical concentration measures based on actual market shares, the measure of physician concentration used in this study implies no mechanical relationship with health-care demand.

To analyze the effect of competition on service provision, we focus on how competition among cardiologists impacts the quantity and type of services given to patients with first-

\footnotetext{
${ }^{1}$ See Hemenway et al. [1990], Hillman, Pauly, and Kerstein [1989], Gruber and Owings [1996], Li et al. [2014], and Clemens and Gottlieb [2014], Coey [2014], and Johnson and Rehavi [2015].

${ }^{2} \mathrm{~A}$ recent study, Godager, Iversen, and Ma [2015], assesses the impact of competition on physician referrals.

${ }^{3}$ Similar findings relating physician market power and payments has been shown in Gravelle et al. [2015], Baker et al. [2014], and Kleiner, White, and Lyons [2015].
} 
time acute myocardial infarction (AMI) - commonly referred to as a heart attack - taken to the emergency room. Focusing on heart attacks has a number of advantages for analyzing physician behavior. One advantage is that it is a severe condition in which patients are likely to be inelastic to out-of-pocket payments. This allows us to focus primarily on the decisions and the incentives of the physician. Although physicians may locate based on the expected number of heart attacks in a given area, the exact severity of each individual case is difficult to predict ex ante. In the words of Cutler, McClellan, and Newhouse [2000], "who is to know whether, if he or she suffers a heart attack, it will lead to major impairment or death?" Importantly, the unobserved severity of the heart attack event (i.e., the severity that is not reflected in our detailed diagnosis data) is plausibly not related to the consolidation decisions of cardiologists.

Our estimates show that cardiologists who reside in more concentrated markets provide more services in terms of the intensity of services for patients with identical observable levels of severity. Overall, an increase in the FTHHI of one standard deviation leads to a 5 percent increase in an intensity-weighted number of cardiologist services. The effect of market concentration on service utilization appears to be stronger for more discretionary services. Primarily, we find that market concentration increases the use of cardiac catheterization, but decreases the probability of a less invasive diagnostic test, such as a cardiovascular stress test or myocardial perfusion imaging test, being performed. However, we find no evidence that market concentration has an effect on angioplasty or bypass surgery - intensive treatments performed after diagnostic tests are performed. In terms of health outcomes, higher cardiologist concentration leads to fewer readmissions, but has no impact on mortality.

Given the extensive amount of evidence showing that physician's financial incentives affect treatment choice, ${ }^{4}$ the likely mechanism that translates market concentration to service provision is through payments. The fee-for-service payment system pays physicians for each additional unit of service provided, which provides incentives to supply more services. We explicitly test the assumption that market concentration affects service utilization through price by applying a difference-in-differences specification with capitated episodes - episodes that are not fee-for-service. We find the effect of market concentration

\footnotetext{
${ }^{4}$ Clemens and Gottlieb [2014] examine how physicians responded to a Medicare reimbursement change that occurred in 1997. The authors found that, on average, a 2 percent increase in service prices caused a 3 percent increase in service utilization - a price elasticity of supply of 1.5. Baker [2010] found that orthopedists who began billing for MRIs increased their use of MRIs by 38 percent. Also see Gruber, Kim, and Mayzlin [1999], Spetz, Smith, and Ennis [2001], Grant [2009], and Decker [2009].
} 
on service utilization exists only for fee-for-service episodes, which lends support to the financial incentive mechanism. To further explore this mechanism, we estimate the physician's treatment response to changes in service price. To isolate the physician's financial incentive response, we exploit the relationship between concentration and price using the FTHHI as an instrument. We find the price elasticity of supply ranges between 1.3 and 1.7 in terms of the number of intensity-weighted cardiologist services. Similar to previous studies, our results imply that cardiologists have positively sloped supply curves.

While our overall results are intuitive and consistent with previous results, we also acknowledge and discuss potential biases. We discuss reasons why the potential biases of our estimation strategy would lead us to underestimate the impact of concentration on utilization. Overall, our study forms a link between competition, financial incentives, and service utilization. These findings have implications for antitrust analysis and suggest that changes in organizational structure in a market, such as a merger of physician groups, not only influences the negotiated prices of services, but also the utilization of medical treatments.

\section{Physician Concentration, Service Prices, and Ser- vice Utilization}

Our analysis focuses on three main variables: (1) physician concentration, also referred to as physician "market concentration," or "market power," (2) physician service prices, also referred to as "fees," "payments," or "reimbursements," and (3) service utilization, also referred to as "service provision" and "service use." Service utilization is a measure of the quantity of services provided to the patient. An important part of our study is that these three variables adjust at different frequencies, implying a distinct time horizon governing the determination of each variable.

\subsection{Timing}

Those variables that adjust frequently can be thought of as being determined in the short run, while those variables that adjust only infrequently can be thought of as being determined in the long run. In particular, the three main variables assessed in this studyconcentration, prices, and utilization - can be placed in the following three categories:

- Long Run: Physician Concentration 
- Medium Run: Service Price

- Short Run: Service Utilization

Market concentration is determined by physicians deciding where and with whom to practice, which the data suggest changes sluggishly. As shown in Dunn and Shapiro [2014], physician market concentration was quite steady over the 2005 to 2008 sample period. Generally, areas that were highly concentrated in 2005 remained highly concentrated in 2008. This sticky behavior of physician concentration is likely due to the large sunk costs involved in physician movement. Physicians build large networks of patients which are costly to forfeit.

Physician reimbursements also change slowly, albeit at a somewhat faster pace than concentration. Specifically, physician reimbursement contracts adjust anywhere from once per year to once every five years. Once the reimbursements are set, they are locked in place for the contract period. This sticky behavior of physician service prices is apparent in the data. For instance, Clemens, Gottlieb, and Shapiro [2014] note that jumps in the Bureau of Labor Statistics' (BLS) physician producer price index (PPI) occur regularly in January (beginning of the year), July (middle of the year), and October (beginning of the fiscal year). Likewise, Dunn and Shapiro [2015] note jumps in physician service prices in January.

The decision about how to treat the patient takes place after a health shock occurs. For instance, the physician may decide whether to perform a certain diagnostic test. All three of these variables are unequivocally chosen in an equilibrium setting. However, when a service use decision is made by a physician, it is necessarily made conditional on market concentration and service prices that are already set in place. By contrast, market concentration, and to an extent prices, can only be adjusted based on expectations of service utilization decisions.

\subsection{Physician Concentration}

During the latter half of the 20th century, more and more physicians decided to practice in groups as opposed to solo practices. Whereas in the 1960s almost all physicians (90 percent) had solo practices (Smart [2006]), by the late 1980s this number was down to about half (49 percent). By 2001, only a third (33 percent) of physicians operated as a solo practice (Rebitzer and Votruba [2011]).

As physician groups formed, they emerged and evolved into different organizational structures. Physicians grouped together by specialty or with many specialties (that is, 
a multi-specialty practice). They became associated with health systems or sometimes hospitals (that is, a physician-hospital organization [PHO]). More complex organizational structures evolved where group practices clustered with one another for bargaining purposes. ${ }^{5}$

In this study, we focus on those types of physician organizations where physicians with the same type of specialization are part of the same group or system. Specifically, we focus on consolidation among cardiologists. This type of "horizontal" consolidation has clear implications in terms of its impact on leverage with insurers. An insurer must have enough cardiologists in its network to attract and adequately treat enrollees. Cardiologists with fewer competitors have more leverage with insurers because their exclusion from an insurance carrier's network can cause greater harm to the insurer's profitability. Generally, the fewer competitors the cardiologist firm has, the higher the fees it can extract from the insurer. Indeed it has been empirically shown that cardiologists have higher reimbursements in more concentrated physician markets (Dunn and Shapiro [2014]).

\subsection{Service Price and Service Utilization}

The link between concentration and utilization is likely formed through the physician's service price. That is, market power raises service prices, altering the physicians' financial incentives to provide services. It is therefore important to discuss how prices may impact service utilization.

The mechanism by which service prices affect service utilization is fairly straightforward. Similar to most firms, a physician firm's marginal cost curve is upward sloping. A physician's capacity is constrained in the short run and thus each additional service provided to the patient cuts into the physician's leisure time. In the longer run, the physician can expand the quantity of services through other means, such as physical or human capital investment. The physician's marginal cost curve is upward sloping when both of these responses become increasingly more costly with service provision - for instance, through diminishing marginal utility of leisure or convex capital adjustment costs.

\footnotetext{
${ }^{5}$ For example, two physician groups may have distinct offices and administrative services, but may contract with insurance carriers for legal bargaining purposes as an independent practice association (IPA). In most states, IPAs represent physicians who only compete for capitated HMO contracts. For non-capitated contracts, the physicians must negotiate individually unless the FTC rules that they are "clinically integrated" for efficiency reasons (Berenson, Ginsburg, and Kemper [2010]). In another example, two physician groups may join forces to share administrative services (e.g., a group practice without walls $(\mathrm{GPWW}))$ as well as contracting.
} 
Figure 1: Service Price Variation and Service Utilization

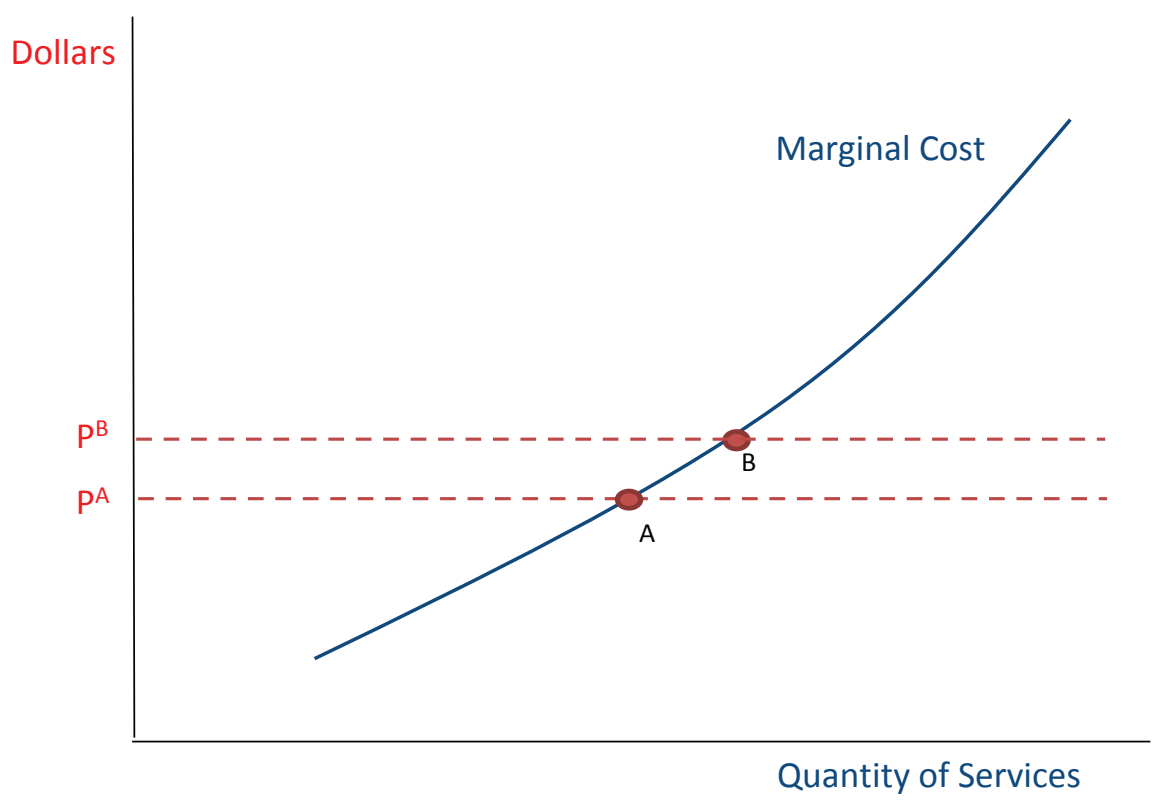

Figure 1 depicts the marginal cost curve of two physicians who have identical costs, Physician A and Physician B. ${ }^{6}$ Physician A has negotiated a price of $P^{A}$ while Physician B has more market power and has negotiated a higher price $P^{B}$. Since the marginal cost curve is upward sloping, the higher service price allows Physician B to provide more services. For instance, the higher service price may encourage Physician B to perform more timeintensive procedures. Over the long run, a higher service price may encourage Physician $\mathrm{B}$ to invest in new technologies because it raises the expected profitability (Chandra and Skinner [2012]). Such types of "practice-style" responses to payment increases were found for physicians by Clemens and Gottlieb [2014] and for hospitals in Finkelstein [2007] and Acemoglu and Finkelstein [2008]. ${ }^{7}$ Historically, since physician consolidation typically

\footnotetext{
${ }^{6}$ This example hinges on the payment difference being exogenous. We expound on endogeneity concerns in Section 4. We assume that the patient is not sensitive to the service price, which is reasonable if the patient's out-of-pocket expenses are only a fraction of actual payments.

${ }^{7}$ There is variation in terms of heart attack treatment capabilities across the United States. For instance, according to a 2004 study (Keeley and Grimes), fewer than one in five facilities in the U.S. even have cardiac catheterization capabilities, and even fewer have the capability to perform angioplasty. There is also medical evidence showing that the capabilities of the facility impacts how the patient is treated. A study by Popescu Vaughan-Sarrazin, and Rosenthal [2007] found that by 30 days after the AMI, 49.1 percent of AMI patients initially admitted to a facility that had revascularization capabilities received coronary revascularization, while this rate was 25.4 percent for patients initially admitted to a facility
} 
occurs over a long horizon, our analysis may be capturing both short-run and long-run incentives of physicians. ${ }^{8}$

Most models of physician treatment decisions also include the physician's concern for the patient's welfare (e.g., McGuire and Pauly (1991)). That is, the patient's utility directly enters the physician's utility function. In this case, the physician may not always respond to price. Rather the physician is more likely to respond to price in cases where the patient is less likely to be harmed or where there is more discretion in the choice of treatment. This type of varying response of price to utilization as a function of discretion was found in Clemens and Gottlieb [2014]. Overall, the supply response to price, discussed above, is likely to be dampened when there is more certainty surrounding the treatment choice.

\subsection{Treatment for Heart-Attack Patients}

This study focuses on the treatment for acute myocardial infarction (AMI), commonly referred to as a heart attack. An AMI occurs when blood cannot flow properly to the heart (i.e., ischemia) due to a blocked coronary artery. When the heart tissue is deprived of oxygenated blood it begins to damage the heart muscle, referred to as an infarction. In most cases, during the onset of an AMI, the person experiences chest pain which usually occurs gradually over several hours. Many patients who experience a heart attack have a history of treated cardiovascular conditions, however, it is common to have had no treated cardiovascular conditions before the AMI occurs - what we label in this study as an "unexpected AMI." For example, 75 percent of patients hospitalized with an AMI have cholesterol levels below what national guidelines classify as high risk (Sachdeva et al. 2009). ${ }^{9}$

Medications, such as aspirin or beta blockers, may be given immediately to reduce the patient's heart rate and blood pressure. However, before restoring blood flow to the heart, cardiologists must evaluate the severity via diagnostic procedures. The cardiologist

without revascularization capabilities. The study used data collected between 2000 and 2005. Of those AMI patients admitted to hospitals without revascularization capabilities, 30.6 percent were transferred to a second hospital, 98.2 percent of those transfers to a hospital with revascularization capabilities.

${ }^{8}$ Simply put, there is very little time-series movement in physician concentration over the sample period studied. Areas that were relatively concentrated in the beginning of our sample, 2005, were also relatively concentrated towards the end of our sample in 2008. We show that instrumenting using a lagged value of concentration implies similar results.

${ }^{9}$ About 25 percent of heart attacks occur without warning signs, and sometimes occur without any symptoms - commonly called a "silent heart attack" (see http://www.webmd.com/heartdisease/understanding-heart-attack-basics). 
has some discretion in choosing a diagnostic procedure. She can choose smaller scale diagnostic procedures such as blood tests, stress tests, echocardiograms, and myocardial perfusion imaging tests. ${ }^{10}$ She can also choose to perform a more invasive diagnostic procedure called a cardiac catheterization. This involves passing a flexible tube into the heart and injecting a radiopaque dye which allows the cardiologist to check blood flow in the coronary arteries and chambers inside the heart to determine the amount of blockage.

Once the severity of the heart attack is determined, a treatment option is chosen. Treating the heart attack entails returning blood flow to the heart in order to mitigate further damage. More intensive procedures include coronary artery bypass grafting (CABG) (i.e., bypass surgery) and angioplasty, while less intensive treatments include blood thinners, anticoagulants, thrombolytic therapy, and heart monitoring. CABG, which is performed by a cardiovascular surgeon, involves major open-heart surgery where blood flow is restored through grafts to the coronary arteries. Angioplasty, which is usually performed by a cardiologist, involves threading a catheter with a balloon at its tip to the affected artery. The balloon is then inflated to compress the plaque inside the artery which allows blood to flow to the heart. A stent may then be placed in the artery to keep the blood vessel open. ${ }^{11}$ Once treated, the patient will see the cardiologist for office-visit checkups which may involve further diagnostic testing and heart monitoring.

\section{Data}

This study has two primary data sets. We use the MarketScan Commercial Claims and Encounters Database, which tracks claims from providers through a nationwide convenience sample of patients. Second, we use the SK\&A physician database, which includes information on location, specialty, unique physician identifiers, medical practice group, and health system of physicians in the United States. In addition to these two data sets, we also use data from three other sources to construct control variables. ${ }^{12}$

\footnotetext{
${ }^{10}$ Myocardial perfusion imaging tests, often called nuclear stress tests, are non-invasive imaging tests showing blood movement through the heart muscle. A cardiovascular stress test is where the cardiologist monitors the patient's heart while the patient is on a treadmill or stationary bicycle.

${ }^{11}$ Not all cardiologists are trained to perform a catheterization or an angioplasty. Indeed, bypass surgery is generally performed by a cardiovascular surgeon as opposed to a cardiologist. However, all cardiologists are trained to determine how and when certain diagnostic tests and medical treatments are needed.

${ }^{12}$ These data come from HealthLeaders-Interstudy, the Area Resource Files (ARF) produced by the U.S. Department of Health and Human Services, and the behavior risk factor surveillance system (BRFSS) produced by the Centers for Disease Control and Prevention.
} 


\subsection{MarketScan ${ }^{\circledR}$ Data}

The MarketScan ${ }^{\circledR}$ database tracks claims from health-care claims spanning 2004 through 2009, although as we explain below our analysis is run on AMIs that occurred between 2005 and 2008. The data include health claims from employers and insurance carriers throughout the U.S. which have been paid and adjudicated. Geographic information is provided about the provider's county of practice. Information is also provided about the type of provider, which allows us to separate payments made to cardiologists from those paid to other providers such as, hospitals, pharmacies, and other types of physicians. We use the MarketScan's "payment" variable, often referred to as the "allowed amount," which is the amount of dollars eligible for payment after applying pricing guidelines such as fee schedules and discounts, and before applying deductibles and copayments. MarketScan also indicates the type of plan under which the claim was made, which allows us to isolate episodes in which a capitation payment was made. ${ }^{13}$

\subsubsection{Medical-Care Spending Per Episode}

We focus on those patients, ages 19 to 63, with a first-time heart attack (ICD-9-CM 410) treated in the emergency room and then track services given for 90 days afterwardwhat we define as an "episode of care." A 90-day window is common in the literature and encompasses virtually all of the intensive care provided to heart attack patients. ${ }^{14}$ We remove individuals age 64 and older because these people may be enrolled in Medicare during part of the episode. We also removed individuals who died on the day of the AMI, as well as individuals who were not admitted to the hospital. We isolate first-time AMI episodes by keeping only those episodes where the patient (1) had no previous AMI diagnosis in the entire MarketScan sample and (2) was in MarketScan's enrollee file the year before the AMI. ${ }^{15}$ Our analysis assesses first-time AMIs that occurred between 2005 and 2008, but we use extra years of data, 2004 and 2009 MarketScan data, to help create this sample. Specifically, we use the 2004 MarketScan to identify whether the enrollee had an AMI diagnosis in the year before the beginning of our sample period and use the 2009 sample to assess spending for episodes that began in November and December of 2008.

We also create a second sample labeled "unexpected first-time AMIs." This subsam-

\footnotetext{
${ }^{13}$ Approximately 4 percent of our sample are capitated episodes. Although our main analysis excludes capitated episodes, we include them in a difference-in-differences specification (Table 8).

${ }^{14}$ See Altman, Cutler, and Zeckhauser [2003], Cutler, McClellan, and Newhouse [1998a, 1998b, 2000].

${ }^{15}$ The enrollee file is a separate data file from the insurance claims and tracks whether an individual was enrolled in a health plan, regardless of whether or not she received care.
} 
ple of the full sample isolates those first-time AMI patients who were not treated for any cardiovascular-related conditions before the AMI. These patients possibly had less knowledge of their general cardiovascular condition before the AMI occurred. As we will discuss later in more depth, the severity of these types of heart attacks is plausibly more random ex ante, which helps with identification in our empirical analysis. Please see the appendix for a comprehensive overview of the data construction.

Total spending for the episode of care is simply the sum of all dollars paid to health-care providers during the 90-day period after the heart attack. This spending can be divided into two mutually exclusive provider categories: cardiologist and noncardiologist spending. The latter includes spending by facilities, laboratories, and other types of physicians, for example, radiologists and anesthesiologists. We removed providers making treatments that likely were not related to the AMI, for example, orthopedists. Table 1 summarizes spending by category. Total reimbursements paid to the cardiologist, our primary focus of this study, includes the payment for any service line provided by what MarketScan identifies as a cardiologist. We removed episodes where a cardiologist payment was not present, as these are episodes where MarketScan could not identify the type of provider. ${ }^{16}$ Spending by a non-cardiologist is analogous and includes payments to any provider who is not labeled a cardiologist, but treats the patient within 90 days after the AMI. We provide explicit details on how we cleaned the data in Appendix A.

The top portion of Table 1 shows summary statistics on spending in the MarketScan data. The average spending for an AMI is $\$ 33,851$ in terms of total reimbursements to providers. The number is roughly equivalent in the sample of unexpected AMIs. Although a small portion of overall spending is paid to the cardiologist, she still receives a large absolute amount of reimbursements per AMI $(\$ 2,258)$. Moreover, as the primary decision maker in terms of treatment, it is possible that procedures provided by other provider types are affected by the cardiologist's incentives. We explicitly test this assumption in our empirical analysis.

\subsubsection{Cardiologist Service Prices and Utilization}

A major advantage of examining physician services is that reimbursements paid to physicians are based on well-defined procedures categorized by Current Procedural Termi-

\footnotetext{
${ }^{16}$ To be conservative, we kept only those episodes with at least two procedures performed by a cardiologist, see Appendix A for more details.
} 


\section{Table 1: MarketScan ${ }^{\circledR}$ Summary Statistics}

\begin{tabular}{|c|c|c|c|c|c|c|}
\hline \multirow[b]{2}{*}{ Variable } & \multicolumn{3}{|c|}{$\begin{array}{c}\underline{\underline{\text { All }}} \\
\underline{\text { First-Time AMI }}\end{array}$} & \multicolumn{3}{|c|}{$\frac{\text { "Unexpected" }}{\text { First-Time AMI }}$} \\
\hline & Mean & S.D. & (Min, Max) & Mean & S.D. & (Min, Max) \\
\hline \multicolumn{7}{|l|}{ Expenditures per Episode } \\
\hline Total Spending $(\$)$ & 33,851 & 22,232 & $(4,388,135,070)$ & 33,737 & 21,686 & $(4,389,134,985)$ \\
\hline Cardiologist Spending $(\$)$ & 2,258 & 1,460 & $(23,15,721)$ & 2,318 & 1,452 & $(24,15,234)$ \\
\hline Non-Cardiologist Spending $(\$)$ & 31,592 & 21,833 & $(537,134,654)$ & 31,419 & 21,284 & $(537,134,654)$ \\
\hline \multicolumn{7}{|l|}{ Cardiologist Service Utilization and Service Price } \\
\hline Cardiologist RVUs & 2,653 & 1,518 & $(49,7,862)$ & 2,721 & 1,523 & $(49,7,862)$ \\
\hline Number of Procedures Performed by Cardiologist & 15.0 & 7.3 & $(2,68)$ & 15.0 & 7.2 & $(2,68)$ \\
\hline Cardiology Service Price (\$ per RVU) & 0.88 & 0.29 & $(0.33,2.53)$ & 0.88 & 0.29 & $(0.33,2.53)$ \\
\hline \multicolumn{7}{|l|}{ Utilization of Specific Procedures } \\
\hline Any Echocardiogram & 0.61 & 0.49 & $(0,1)$ & 0.61 & 0.49 & $(0,1)$ \\
\hline Any Cardiovascular Stress Test & 0.29 & 0.45 & $(0,1)$ & 0.30 & 0.46 & $(0,1)$ \\
\hline Any Myocardial Perfusion Imaging Test & 0.19 & 0.39 & $(0,1)$ & 0.18 & 0.39 & $(0,1)$ \\
\hline Any Cardiac Catheterization & 0.90 & 0.30 & $(0,1)$ & 0.92 & 0.27 & $(0,1)$ \\
\hline Any Angioplasty & 0.64 & 0.48 & $(0,1)$ & 0.68 & 0.47 & $(0,1)$ \\
\hline Any CABG & 0.10 & 0.30 & $(0,1)$ & 0.10 & 0.30 & $(0,1)$ \\
\hline \multicolumn{7}{|l|}{ Health Outcome } \\
\hline Death (discharge status), 90 days & 0.003 & 0.05 & $(0,1)$ & 0.002 & 0.04 & $(0,1)$ \\
\hline Death (discharge status), 365 days & 0.006 & 0.08 & $(0,1)$ & 0.003 & 0.06 & $(0,1)$ \\
\hline Readmission for Any Cardiovascular Condition, 90-365 days & 0.090 & 0.29 & $(0,1)$ & 0.078 & 0.27 & $(0,1)$ \\
\hline Readmission for AMI, 90-365 days & 0.007 & 0.09 & $(0,1)$ & 0.006 & 0.08 & $(0,1)$ \\
\hline \multicolumn{7}{|l|}{ Patient Demographics and Health Status } \\
\hline Age & 53.1 & 7.5 & $(19,63)$ & 52.1 & 7.8 & $(19,63)$ \\
\hline Male & 0.74 & 0.43 & $(0,1)$ & 0.76 & 0.42 & $(0,1)$ \\
\hline Charlson Comorbidity Index (within 365 days before AMI) & 0.47 & 1.04 & $(0,13)$ & 0.26 & 0.74 & $(0,9)$ \\
\hline Inpatient admission within 365 days before AMI & 0.024 & 0.154 & $(0,1)$ & 0.009 & 0.092 & $(0,1)$ \\
\hline \multicolumn{7}{|l|}{ Diagnosis Code (ICD-9) } \\
\hline 410.0 (Anterolateral Wall) & 0.04 & 0.20 & $(0,1)$ & 0.04 & 0.20 & $(0,1)$ \\
\hline 410.1 (Other Anterior Wall) & 0.13 & 0.33 & $(0,1)$ & 0.14 & 0.35 & $(0,1)$ \\
\hline 410.2 (Inferolateral Wall) & 0.04 & 0.19 & $(0,1)$ & 0.04 & 0.20 & $(0,1)$ \\
\hline 410.3 (Inferoposterior Wall) & 0.02 & 0.15 & $(0,1)$ & 0.03 & 0.16 & $(0,1)$ \\
\hline 410.4 (Other Inferior Wall) & 0.20 & 0.40 & $(0,1)$ & 0.22 & 0.41 & $(0,1)$ \\
\hline 410.5 (Other Lateral Wall) & 0.02 & 0.13 & $(0,1)$ & 0.02 & 0.13 & $(0,1)$ \\
\hline 410.6 (True Posterial Wall) & 0.01 & 0.07 & $(0,1)$ & 0.01 & 0.07 & $(0,1)$ \\
\hline 410.7 (Subendocardial) & 0.42 & 0.49 & $(0,1)$ & 0.40 & 0.49 & $(0,1)$ \\
\hline 410.8 (Other Specified Site) & 0.01 & 0.12 & $(0,1)$ & 0.01 & 0.11 & $(0,1)$ \\
\hline \multirow[t]{2}{*}{410.9 (Unspecified Site) } & 0.13 & 0.34 & $(0,1)$ & 0.12 & 0.33 & $(0,1)$ \\
\hline & \multicolumn{3}{|c|}{$\mathrm{N}=11,846$} & \multicolumn{3}{|c|}{$\mathrm{N}=6,862$} \\
\hline
\end{tabular}


nology (CPT) codes. ${ }^{17}$ By contrast, reimbursements for inpatient hospital stays are priced in more complex fashion where the pricing methodology changes depending on the specific contract between each insurer and provider (see Reinhardt [2006]). ${ }^{18}$ The relatively straightforward manner in which physician reimbursements are set allows us to decompose cardiologist expenditures into a service price and service utilization component in a feasible manner.

Our calculation of the cardiologist's service price is based on the methodology by Dunn, Shapiro, and Liebman [2013] and is calculated using all procedures provided by the cardiologist to the patient over the course of the 90-day episode. There is a three-step process in obtaining a measure of service prices. First, we obtain the physician expenditure for a particular episode of care. Second, we quantify the amount of services performed by the physician during the episode of care. Finally, we calculate the service price as defined as the expenditure divided by the quantity of services. First note that the total expenditures made to the cardiologist for treating episode $n$ is:

$$
T E_{n}=\sum_{j \in \Gamma_{n}} p_{j n}
$$

where $p_{j n}$ is the full payment (including the patient's out-of-pocket costs) to the cardiologist for procedure $j$ in episode $n$. The variable $\Gamma_{n}$ is the set of all procedures given to the patients within 90 days of the AMI. Pricing information for a specific procedure is the payment attached to the specific health claim line in the MarketScan data. We identify procedures $j$ at the most granular level possible, based on a specific CPT code including its modifier. Note that each episode uniquely identifies an individual patient, treated by a cardiology firm that resides in a specific county that begins in a specific year. ${ }^{19}$

Next, we calculate the quantity of services per episode of care which we refer to as "service utilization." We measure this variable by the following:

\footnotetext{
${ }^{17}$ Due to the fact there are thousands of different CPT codes, physicians usually negotiate the prices of all CPT codes at once based on a fee schedule - for example, all prices set relative to Medicare prices (see Clemens and Gottlieb [2014]).

${ }^{18}$ For example, inpatient hospital contracts may be based on a discount off of charges, a per diem rate, or price based on the diagnosis code (i.e., DRG code) of the patient.

${ }^{19}$ We removed those episodes where there was more than one county associated with the cardiologist. In our analysis, we cannot be sure that there was only one cardiology firm treating the patient. Although MarketScan does provide physician IDs, they are available for only about half of the available MarketScan data. Given the limited size of the sample of AMI patients we decided to ignore this variable.
} 


$$
Q_{n}=\sum_{j \in \Gamma_{n}} r_{j}
$$

where, as in Dunn, Shapiro, and Liebman [2013], $r_{j}$ is proxied by the average price of procedure $j$ in the entire MarketScan sample. That is, $r_{j}$ serves as a proxy for the intensity of services rendered for a given procedure. Thus, one can think of $r_{j}$ as being comparable to each procedure's relative value units (RVUs) assigned by Medicare. Any variation in the utilization component between two episodes of care will be attributable only to differences in the number and intensity of services provided, as opposed to differences in the prices charged for the same service. For instance, an episode that includes two 30 minute visits will count as a larger number of RVUs than an episode with one 30 minute and one 15 minute office visit. In our analysis that follows, we will refer to service utilization, $Q_{n}$, as the quantity of RVUs per episode.

The remaining component of the cardiologist's expenditure of an episode of care is the service price:

$$
P_{n}=\frac{T E_{n}}{Q_{n}}
$$

which is the price of the episode of care in terms of its total price per service. The cardiologist's service price is simply the amount of dollars paid per RVU. Note that there is a simple relationship between total expenditures and service price and utilization:

$$
\ln \left(T E_{n}\right)=\ln \left(P_{n}\right)+\ln \left(Q_{n}\right)
$$

Table 1 shows summary statistics ${ }^{20}$ for cardiologist service price and utilization, as well as additional variables that will be analyzed in this study, such as the use of specific procedures and health outcomes. ${ }^{21}$ Note that the average service price will lie close to 1

\footnotetext{
${ }^{20}$ As part of cleaning the data, we removed outliers we believe are attributable to clerical data input error by discarding episodes in the bottom 1st percentile and top 99th percentile based on price and utilization. Please see Appendix A for more details.

${ }^{21}$ The mortality rate appears low for two reasons. First, we removed patients who died on the day of the AMI or who were not admitted to the hospital at least one night. The mortality rate, including these individuals who died the day of the AMI, is 1.6 percent for those age 60 and under and is 3.1 percent for those age 60-64. Second, we only have information on the discharge status of the individual. We have no information whether the individual died before being treated. The inpatient mortality data in MarketScan appears reasonable when compared to external inpatient data sources on AMIs. Specifically, using inpatient discharge data for AMI commercially insured patients under 65 from the Pennsylvania Health Care Cost Containment Council for the years 2002-08, we find a mortality rate of 2.9 percent.
} 
by construction - RVUs are constructed as the average price of the CPT code based on the entire MarketScan sample.

Around 90 percent of heart attack patients received a cardiac catheterization. A smaller fraction received less invasive diagnostic procedures - approximately 60 percent received an echocardiogram, 30 percent received a stress test, and 20 percent received myocardial perfusion imaging. Approximately 70 percent (not shown in Table 1) of patients received a less invasive type of diagnostic test: either an echocardiogram, stress test, or myocardial perfusion imaging (MPI). ${ }^{22}$ In terms of the RVU metric employed in this study, a catheterization is much more intensive than any of these less invasive diagnostic tests. For instance, the most common type of catheterization (CPT code 93510) amounts to 1,244 RVUs, while the most common type of MPI test (CPT code 78465), echocardiogram (CPT code 93307), and stress test (CPT code 93015) amount to 587, 236, and 143 RVUs, respectively. Appendix B shows how we mapped CPT codes into procedure types and also lists the top 20 CPT codes used among cardiologists in our sample.

We can also control for the primary diagnosis (ICD-9) code reported during the episode of care. Specifically, this variable indicates the type of heart of attack that occurred during the episode as diagnosed by the cardiologist. ${ }^{23}$ Approximately 2 percent of episodes indicated more than one primary diagnosis code. A large proportion of AMIs in the sample (40 percent) are subendocardial infarctions, which is a heart attack that involves the innermost layer of the myocardium.

Table 1 also reports measures of the patient's health status before the AMI occurred. One measure is the Charlson comorbidity index (CCI) which is calculated by assessing the diagnosis codes of the patient in the 365 days leading up to the heart attack. ${ }^{24}$ Another measure is an indicator of whether the patient was ever admitted to a hospital in 365 days before the AMI occurred. By construction, patients with an unexpected AMI (i.e., those without any cardiovascular preconditions) are more likely to have lower values of these health indicator variables, on average. However, besides these differences in patients' health

\footnotetext{
${ }^{22}$ Of the 1,128 AMI patients who did not receive a catheterization, 912 received either an echocardiogram, stress test, or MPI.

${ }^{23}$ We dropped episodes where the only ICD-9 reported during the episode had a fifth digit of the ICD-9 equal to "2," (e.g. 410.12 and 410.22) which indicates a subsequent AMI. See Appendix A.

${ }^{24}$ The CCI assigns scores as follows: 1 each for AMI, congestive heart failure, peripheral disease, cerebrovascular disease, dementia, chronic pulmonary disease, peptic ulcer disease, mild liver disease, diabetes without end-organ damage. 2 each for hemiplegia, moderate or severe renal disease, diabetes with endorgan damage, tumor with metastasis, leukemia, lymphoma. 3 for moderate or severe liver disease. 6 for metastatic solid tumor and AIDS.
} 
status before the heart attack occurs, there are no large apparent differences in spending or service use between the full sample and the sample of patients with unexpected AMIs. Patients who suffer an unexpected AMI are a year younger, on average, and also have a slightly lower probability of dying in the hospital within 90 days of the AMI. These small differences are to be expected, since the discovery of cardiovascular conditions are likely to increase with age, along with the conditional probability of dying of a heart attack. It is important to note that the bulk of dollars are paid to the facility for services, such as imaging, room and board, and laboratory services.

\section{$3.2 \quad \mathrm{SK} \& \mathrm{~A}^{\circledR}$ Data}

The measure of cardiologist market concentration used in our analysis is taken from Dunn and Shapiro [2014] and is labeled the "fixed-travel-time" HHI (FTHHI). The FTHHI is constructed from the $\mathrm{SK} \& \mathrm{~A}^{\circledR}{ }^{\circledR}$ database of physicians and includes information on physician location (geocode), specialty, name, medical practice group, and health system. The database is updated every six months (half-year), spans 2005 to 2008, and claims to include 95 percent of office-based physicians practicing in the United States. ${ }^{25}$

The FTHHI is based on the assumption of a market boundary defined by a fixed driving time between the patient and the physician firm. There is a four-step process in creating the FTHHI. First a geographic market boundary is defined. Second, the probability that a person located within the market boundary will visit a physician firm is constructed. Third, using the probabilities of seeing each physician calculated in step two, an expected market share is calculated. Fourth, using the expected market shares and physician group information, a concentration measure (the FTHHI) is created which is specific to a county and time period. See Appendix C for details on how the FTHHI is constructed.

The important feature of the FTHHI, relative to other types of concentration measures,

\footnotetext{
${ }^{25}$ SK\&A has a research center that verifies every field of every record in its database. The data also include the names of DOs, NPs, PAs and office managers. The SK\&A data do not state whether physicians in the data are part of a larger system that also owns hospitals or ambulatory care facilities. An important benefit of the SK\&A data relative to other data sources is that they provide information about physician medical practice groups (i.e., firms). Another advantage is that each physician is verified over the telephone, which increases the accuracy of its physician location and group size information. The six month frequency of their telephone survey may be important, since SK\&A reports that on average, $14.2 \%$ of physicians move each year. Although all the information in the survey is telephone verified, they gather information for physicians through a variety of sources. This includes company and corporate directories, websites, state licensing information, mergers and acquisitions announcements, trade publications, white and yellow pages directories, professional associations, and government agencies.
} 
Table 2: SK\&A ${ }^{\circledR}$ Summary Statistics

\begin{tabular}{l|cc|ccccc} 
& Mean & Std. Dev. & Min & 25th Pctl. & Median & 75 th Pctl. & Max \\
Variable & & & & & & & \\
\hline Cardiologist FTHHI & 0.160 & 0.211 & 0.003 & 0.034 & 0.086 & 0.189 & 1 \\
Cardiologists per Ten Thousand Persons & 0.697 & 0.462 & 0.030 & 0.437 & 0.618 & 0.871 & 11.6 \\
Cardiologists per Firm & 3.57 & 3.78 & 1 & 2.07 & 2.92 & 4.2 & 140
\end{tabular}

is that it is calculated solely on information about the physician's group size and distance to patients. It does not include any information about the physician firms' actual shares which may cause it to be mechanically related to patients choosing specific physicians. Based on the results of Dunn and Shapiro [2014], we choose to use the FTHHI measure with a market boundary set to 80 minutes. All of the estimates in this study are robust to changes in the radius to 60 and 100 minutes. Table 2 reports summary statistics of the FTHHI as well as other variables from the SK\&A database used in our analysis.

\section{Identification}

The ideal experiment to assess how market structure impacts service provision would involve randomly assigning physicians to markets with different degrees of concentration. Our study is obviously limited in this regard as we can only assess observed geographic differences in market concentration. Since observed differences in physician market structure are determined endogenously by physicians' consolidation decisions, it is important to discuss how this might confound the results in our study.

The main identification assumption in our empirical analysis is that concentration is not correlated with unobserved factors influencing cardiologist service utilization for a heart attack event. That is, we are concerned about factors we do not observe as econometricians, that may be correlated with both concentration and service utilization. In this section, we highlight three key categories of such variables: (1) the patient's out-of-pocket price sensitivity, (2) the physician's unobservable cost, and (3) the patient's unobserved health severity. We also discuss issues of physician concentration measurement and its potential impact on our estimates.

In discussing the link between concentration and utilization, it is important to discuss the role of price. Given previous research documenting that physician's supply decisions are price sensitive (e.g., Clemens and Gottlieb [2014]), the mechanism by which concentra- 
tion affects service utilization is plausibly through its effect on service price. The increased price obtained from negotiating clout in more concentrated markets increases the marginal profitability of additional services. This mechanism may be formally tested by using physician concentration as an instrument for the service price, when analyzing the impact of service price on utilization. This instrumental variable (IV) analysis not only bolsters our identification argument, it also allows for direct measurement of physician price sensitivity. Given that the three variables, concentration, price and utilization, are central to our analysis, the following subsection discusses the relationship among these variables.

\subsection{Consumer Price Sensitivity}

If concentration impacts prices, this could have an impact on utilization through the patient's response to out-of-pocket price through coinsurance rates (Chandra, Gruber, and McKnight [2010]). We argue that our analysis is isolating the decision of the physician and not the patient for two reasons. First, this paper focus on the intensive margin of service use (i.e., the quantity of services given a heart attack) that is arguably more influenced by the physician, in general, than the extensive margin (i.e., the choice to seek treatment) that is more influenced by the patient (Keeler and Rolph [1988]). Second, and perhaps more importantly, one advantage of focusing on a heart attack event is that it is a severe condition in which patients are likely to be inelastic to out-of-pocket payments, which allows us to isolate the procedure decisions and the incentives of the physician. To the extent that patient price sensitivity has any effect, it will lead us to underestimate the effects of concentration on utilization.

\subsection{Unobserved Cost, Quality, and Productivity}

A significant portion of a physician's marginal cost and productivity may be unobserved to the econometrician. For instance, some physicians may be more or less productive while others may place a larger or lesser value on their leisure time. Figure 2 shows a depiction of a stylized model intended to show how unobserved variation in marginal cost could interfere with identifying the physician's response to marginal changes in price. We then discuss how this identification issue relates to measuring the effect of physician concentration on utilization.

Figure 2 is split into two panels. Panel $(i)$ reproduces what was shown in Figure 1. Physicians A and B share the same marginal cost curve, but Physician B has negotiated a higher payment rate than Physician A. There is also the addition of a vertical line marking 
the minimum acceptable level of services that the physician must provide the patient. This assumption is equivalent to consumers purchasing health insurance knowing that, should a heart attack occur, some minimum threshold of care would be provided.

Panel (ii) includes a third physician, Physician C, who has a higher marginal cost curve than Physicians A and B, but has a negotiated price identical to Physician B. Physician C's marginal cost curve reflects that she might be less productive or may place a larger value on her leisure time than Physicians A and B. In either case, it costs Physician C more at the margin than Physicians A and B to supply the same amount of care to the patient. The important point is that it is conceivable that each physician's expected cost is known by the physician when prices are set, or perhaps when consolidation considerations are made.

In panel (ii), Physician $\mathrm{C}$ negotiates a higher service price than Physician A to ensure that the minimum amount of services is provided. In this case, a higher price is associated with fewer services. ${ }^{26}$ The key difference between panels $(i)$ and $(i i)$ is that a price increase from greater bargaining leverage unambiguously increases the physician's per-service profit margin while a price increase attributable to cost does not. This example demonstrates one potential way that unobserved variation in physician cost could cause service price and utilization to be negatively correlated. ${ }^{27}$

A key assumption in our empirical analysis is that market concentration varies independently from costs that are unobservable to the econometrician. Since consolidation is a long-run decision, the assumption is tantamount to assuming that physicians do not make consolidation decisions based on expected unobserved costs. One way to test this assumption is to compare an OLS estimate of service price on service utilization directly with that of an IV estimation using concentration as an instrument for price. If physicians are price sensitive and concentration is uncorrelated with unobserved costs, then we would expect the IV estimate of the supply elasticity to be larger (i.e, more positive) than the OLS coefficient.

If there is an unobserved cost factor related to concentration and service price, Figure

\footnotetext{
${ }^{26}$ As an alternative to including a line for the minimum amount of services, the higher cost of Physician C could also be associated with her ability to negotiate a higher price than Physician A. The higher marginal cost for Physician $\mathrm{C}$ raises her threat point, relative to Physician A, and may be a key determinant in negotiating a higher service price than Physician A. That is, a higher marginal cost will likely be associated with a higher negotiated service price.

${ }^{27}$ As an alternative but related example, it may be that Physician $\mathrm{C}$ is of higher quality, so the marginal costs of her treatments are greater, but the amount of services necessary to treat the patient are actually less (e.g., requires fewer diagnostic tests for the same treatment).
} 
Figure 2: Price Variation Attributable to Cost
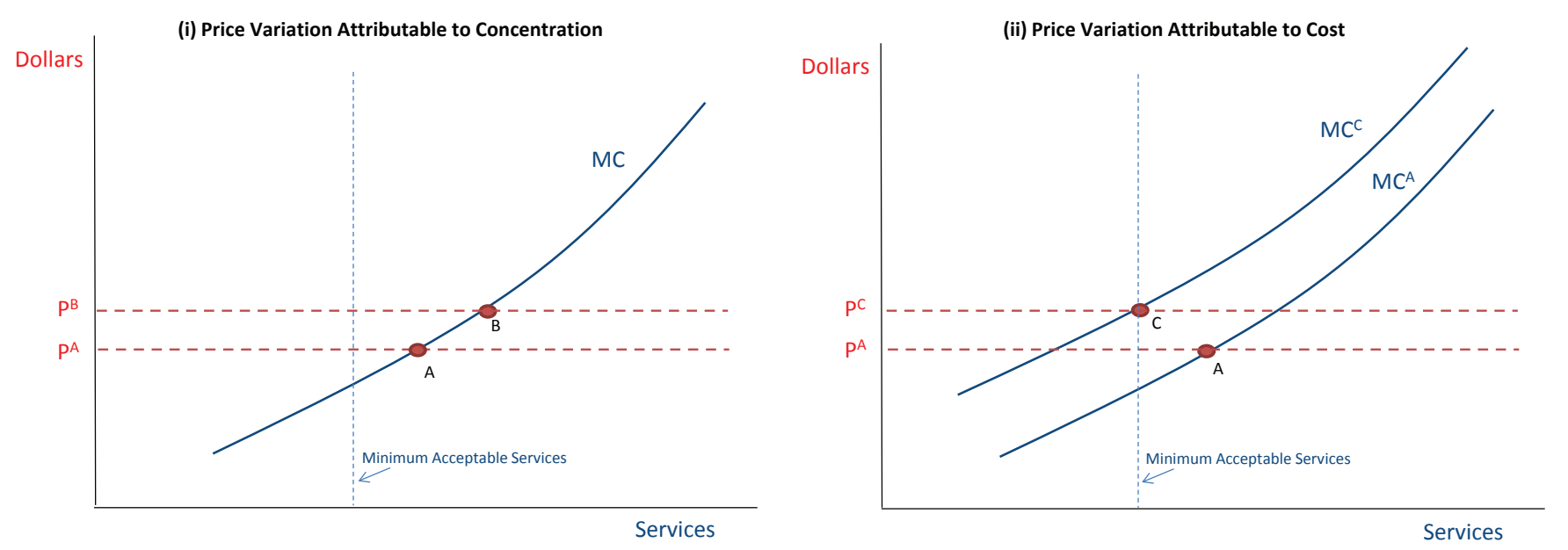

2 shows that this bias would lead to an underestimate of the effects of concentration on utilization. When physicians expect costs to be high, the physicians may have an incentive to consolidate or simply leave the market. Physicians leaving or consolidating would lead to greater physician leverage in the market and higher reimbursements, overcoming the high costs. This would cause concentration to be high when costs are also high. However, note that Figure 2 implies that, all else equal, high costs are associated with lower service utilization. Thus, this type of physician movement would cause us to underestimate the the true effect of concentration on service utilization.

\subsection{Unobserved Health Severity of First-Time AMI Patients}

As argued previously, the severity of heart attacks are unpredictable, making it unlikely that the unobserved component of heart attack severity would be correlated with the consolidation of physicians in an area. However, it is important to discuss how omittedvariable bias due to unobserved (to the econometrician) health severity would affect our results. Panel (ii) of Figure 3 shows where a fourth physician, Physician D, treats patients who, on average, have more severe health shocks. For instance, this could be the leading specialist in the area, who only sees the most severe patients. Since these are patients who need more health services, the minimum acceptable services is shifted to the right.

Physician D expects that she is likely to treat severe health conditions, meaning the average minimal amount of acceptable services is quite high. Similar to the case with marginal cost variation, Physician D then negotiates a higher service price simply to ensure 
that the minimum amount of services is provided. Figure 3 demonstrates that unobserved variation in health severity could cause upward bias on OLS regression of service price on service utilization.

Figure 3: Price Variation Attributable to Severity
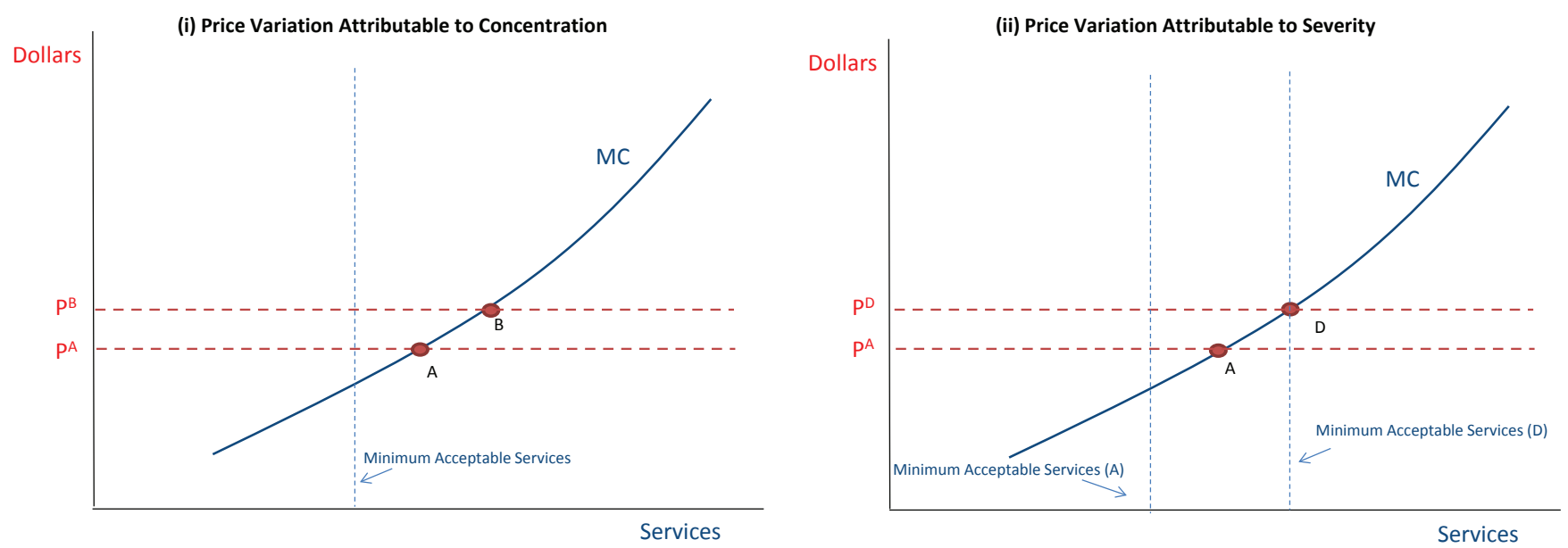

The key assumption concerning health severity in our main analysis is that it varies independently from concentration. To be clear, physicians likely choose to locate in areas where they expect a large number of heart attacks to occur. For instance, physicians may choose to locate in an area with more smokers (or consolidate in an area with fewer smokers). In this case, more competitive markets may be associated with unhealthy geographic areas or an older population. However, conditional on a heart attack occurring, physicians are plausibly less able to predict the severity of the heart attack. This identification assumption is similar to Cutler, McClellan, and Newhouse [2000]. Coey [2014], who also examined MarketScan data, found this to be true for patients, finding no evidence that patients with less severe heart attacks selected into more restrictive plans.

Our subsample analysis on "unexpected" AMI patients further helps mitigate this type of potential omitted-variable bias. It is also important to point out that in our empirical analysis we include many variables that control for observable severity such as the patient's age, gender, Charlson comorbidity index $(\mathrm{CCI})^{28}$ and a dummy variable indicating the specific diagnosis code of the AMI (ICD-9 code). ${ }^{29}$

\footnotetext{
${ }^{28}$ Specifically, we include a third order polynomial of the CCI to account for possible nonlinear effects of the patient's health condition going into the AMI.

${ }^{29}$ This includes ten ICD-9 categories - nine dummy variables plus one omitted dummy. See Table 1.
} 
Similar to our discussion with marginal cost variation, it is helpful to sign the bias if this type of omitted-variable bias were to occur. Specifically, if bias were to occur, it would be because physician firms are are more likely to enter the markets where they expect severity to be high. In other words, one would expect more entry where demand for health services is high. This implies that, similar to unobserved cost, any correlation between concentration and unobserved severity would cause us to underestimate the effect of concentration on service utilization.

\subsection{Physician Concentration Measure}

Finally, the measure of physician concentration used in this study is based solely on the distance between physician firms and the relative number of physicians in the firm. ${ }^{30}$ Thus, we do not have to be concerned about the concentration measure mechanically changing because patients choose certain doctors after the health shock occurs. For instance, patients who realize they are very sick may select a more productive physician, raising that physician's market share. ${ }^{31}$ While our measure does not contain this type of bias, there is a potential for measurement error in the physician concentration measure, as discussed in Dunn and Shapiro [2014], which would lead to an attenuation bias and underestimate of the impact of concentration on utilization.

The SK\&A database does not provide reliable information on whether the physician firm is vertically integrated with a facility - that is, whether the physician firm is owned by a hospital or the physician firm owns the facility. ${ }^{32}$ For this reason, the FTHHI incorporates variation due to vertical integration to the extent that the two may be correlated. That is, we cannot rule out the possibility that utilization differences attributable to the FTHHI are stemming from differences in vertical integration. Thus, concentration may have an impact on utilization for reasons over and above just its impact on the size of the physician's payment.

\footnotetext{
${ }^{30}$ In all specifications, we include a control for the average size of the cardiology firm in the market.

${ }^{31}$ If our concentration measure were based on the physician's actual market share, which is not used in this study, physician selection would cause us to mistake unhealthy geographic areas as highly concentrated markets.

${ }^{32}$ See Iglehart [2005] and Robinson and Miller [2014].
} 


\section{$5 \quad$ Estimation Strategy}

The analysis in this paper takes two alternative approaches to identify the effect of concentration on price. One of the approaches estimates this effect as occurring through the financial incentives of physicians. This analysis takes two steps. The first-stage regression entails estimating the effect of cardiologist concentration (FTHHI) on cardiologist service prices - similar to that studied in Dunn and Shapiro [2014]. This establishes the expected positive effect of concentration on price for heart attack services, indicating higher profit margins for physicians in more concentrated markets, all else equal. The second-stage consists of estimating the impact of cardiology service prices on cardiology service utilization, using the FTHHI as an instrument for service price.

As an alternative approach to explore this relationship, we also estimate the direct effect of the FTTHI on cardiology service utilization. For this more direct analysis we also examine the effect of FTHHI on utilization of specific procedures and other types health care providers.

\subsection{First Stage}

The first-stage estimation of the cardiologist's service price, $P_{n}$, takes the form:

$$
\ln \left(P_{n}\right)=\beta \ln \left(F T H H I_{c t}\right)+\delta^{\prime} X+\zeta_{s t}+\varepsilon_{n}
$$

where each 90-day episode of care after the heart attack $(n)$ has a unique year $(t)$ the episode began, as well as county $(c)$ and state $(s)$ where the cardiologist providing care resides. Since the specification includes state-time fixed effects $\left(\zeta_{s t}\right)$, it isolates crosssectional variation in the FTTHI between counties within a state. ${ }^{33}$ Them vector $X$ includes a multitude of covariates that control for demographics of the patient undergoing care, such as age and gender, as well as county-level information that is likely jointly related to the cardiologists' costs and her consolidation decisions. As discussed earlier, the FTHHI is not constructed from actual market shares, but rather the relative distance between physicians and the size of the physician firms. Thus, unlike a standard HHI measure, there is no mechanical relationship between the number of patients getting treated by the cardiologist and the FTHHI that would likely bias our estimates.

Since the age distribution is skewed towards older individuals, we include age dummies specific to the exact age for those individuals above 60 , but five-year age bin dummies

\footnotetext{
${ }^{33}$ We also ran our regression using Metropolitan Statistical Area (MSA)-time fixed effects and got very similar results.
} 
for ages below 60. We also interact a gender dummy with the age dummies. Additional patient-specific variables from MarketScan include the patient's type of insurance carrier (e.g., HMO, PPO, etc.) as well as a dummy variable indicating whether the data source was from an employer. To better control for the patient's health, we include a dummy variable indicating whether the patient was ever admitted to an inpatient hospital before the heart attack occurred, the patient's Charlson comorbidity index, ${ }^{34}$ as well as dummy variables indicating the specific type (ICD-9) of heart attack that did occur.

Our county-level variables are aimed to control for the cardiologist's costs (and capacity), as well as factors that may jointly affect the size of the health shock and the FTHHI. They are specific to the year and the cardiologist's county. Our cost controls include the number of cardiologists per capita, the number of cardiologists per firm, ${ }^{35}$ the number of hospitals per capita, the number of university hospitals per capita, the population density, hospital costs per employee, median house value, the concentration of the insurance market, and median house rental. We also include the median income of the patient's county of residence. To control for factors that may jointly affect the size of health shocks we include information obtained from the Center for Disease Control and Prevention's (CDC) Behavioral Risk Factor Surveillance System (BRFSS) as well as the entire MarketScan database. From BRFSS we calculate a prediction of the fraction of individuals in the county who are heavy smokers and the fraction of individuals who are obese. From the entire MarketScan database we generate utilization and prevalence information taken from Dunn, Shapiro, and Liebman [2013], which includes the number of non-cardiovascular related treated conditions per capita, as well as the amount of non-cardiovascular related services per episode of care (i.e., a county-level service utilization index). These latter variables are included to capture the possibility that certain counties may have a relatively large number of unhealthy individuals. The vector $X$ also includes the concentration of the insurance market - the same measure constructed in Dunn and Shapiro [2014]. ${ }^{36}$

\footnotetext{
${ }^{34}$ We include a third-order polynomial of the CCI to control for possible nonlinear effects of health severity.

${ }^{35}$ Firm is defined as the cardiology firm in the SK\&A. Our results did not change when we removed cardiologists per capita or cardiologists per firm as a control.

${ }^{36}$ Insurance markets are plausibly much larger than physician markets, usually covering a multitude of counties. Our results did not change when we excluded this control from our regression analysis or when we included smaller geographic fixed effects such as MSA-time fixed effects.
} 


\subsection{Second Stage}

The second-stage estimation measures the impact of a change in the cardiologist's service price on the amount of services provided to the patient, $Y_{n}$ :

$$
Y_{n}=\gamma \widehat{\ln \left(P_{n}\right)}+\delta^{\prime} X+\zeta_{s t}+\nu_{n}
$$

where we measure the amount of services, $Y_{n}$, using a few different utilization metrics. The controls are the same as that in the first-stage estimation. The hat over the service price indicates that we are instrumenting the cardiologist's service price with the cardiology FTHHI. The coefficient $\gamma$ measures the cardiologist's price elasticity of service supply to the extent that it measures the change in services she provides to the patient due to a change in her margin.

The residual, $\nu_{n}$, represents any unobservable (to the econometrician) factor that affects the amount of services provided to the patient. As discussed in Section $4, \nu_{n}$ likely represents the physician's unobservable cost and/or the patient's unobservable heart-attack severity. As we delineated in Figure 2 of Section 4, there will be downward omitted-variable bias on $\gamma$ under OLS if $\nu_{n}$ represents the physician's unobservable marginal cost. Recall that in this case variations in $\nu_{n}$ are positively related to price but negatively related to $Y_{n}$. Under IV estimation, however, omitted-variable bias on $\gamma$ arises only if the FTHHI is correlated with $\nu_{n}$. Thus, we have to address the concern that the FTHHI could be correlated with either the physician's unobservable marginal cost or unobservable severity of the health shock.

\subsubsection{Signing the Potential Omitted-Variable Bias}

As highlighted in our previous discussion, any remaining omitted-variable bias under IV is likely to be downward, causing us to underestimate $\gamma$. Suppose that $\nu_{n}$ represents unobservable (to the econometrician) cost. In this case, $\nu_{n}$ is negatively correlated with $Y_{n}$ - for a given price, a higher cost translates to a lower margin, and hence less service provided. However, correlation between $\nu_{n}$ and FTHHI, if it arises, is likely to be positivephysicians are prone to consolidate when they expect unobservable costs to be high in order to raise their prices. Since $\nu_{n}$ is positively correlated with FTHHI, but negatively correlated with $Y_{n}$, any omitted-variable bias on $\gamma$ related to unobservable cost is likely to be downward.

Now suppose that $\nu_{n}$ represents unobservable (to the econometrician) heart-attack severity. In this case, $\nu_{n}$ is positively correlated with $Y_{n}$-for a given price, a more severe 
heart-attack likely requires more services to be provided. However, correlation between $\nu_{n}$ and FTHHI, if it arises, is likely to be negative - if physicians expect that an area is prone to very severe heart attacks, more cardiologists are likely to enter the market to meet demand, effectively lowering the FTHHI. Since $\nu_{n}$ is negatively correlated with FTHHI, but positively correlated with $Y_{n}$, any omitted-variable bias on $\gamma$, related to unobservable heart-attack severity, is likely to be downward. Recall that our focus on AMI patients likely mitigates this type of potential omitted-variable bias since it is plausibly difficult to predict heart-attack severity a priori.

The key takeaway is that, omitted-variable bias is theoretically more likely to cause downward bias on $\gamma$. Thus, the estimate in this paper is more likely a lower bound on the true supply elasticity. This implies that omitted-variable bias would not cause any change to our qualitative findings if we find a positive estimate $\gamma$,

\subsection{Direct Estimation of Concentration on Service Use}

For completeness, as well as serving as our main estimate, we directly estimate the effect of the FTHHI on service utilization:

$$
Y_{n}=\theta \ln \left(F T H H I_{c t}\right)+\delta^{\prime} X+\zeta_{s t}+\omega_{n}
$$

where $\theta \approx \beta \cdot \gamma$. Specifically, $\theta$ represents the impact of the physician's market power on the amount of services provided to the patient. Similar to equation (6), the residual, $\omega_{n}$, represents any unobserved cost or unobserved health shock. Thus, the same identifying assumptions apply concerning the correlation between the FTHHI and $\omega_{n}$ as they do between the FTHHI and $\nu_{n}$.

For the same reasons described above, our estimate of $\theta$ is likely a lower bound on the true effect of the impact of concentration on service utilization. For instance, suppose $\omega$ represents unobserved cost. This implies a negative correlation between $\omega_{n}$ and $Y_{n}$ but a positive correlation between $\omega_{n}$ and $F T H H I_{c}$. Similarly, if $\omega$ represents unobserved health severity, this implies a positive correlation between $\omega_{n}$ and $Y_{n}$ but a negative correlation between $\omega_{n}$ and FTH HI $I_{c t}$. 
Table 3: Effect of Cardiologist Market Concentration on Cardiologist Service Price

(1) (2)

\begin{tabular}{lcccc} 
Outcome: & \multicolumn{3}{c}{ Log Cardiologist Service Price } \\
\hline \hline Log FTHHI & $0.038^{* * *}$ & $0.042^{* * *}$ & $0.040^{* * *}$ & $0.045^{* * *}$ \\
& $(0.009)$ & $(0.009)$ & $(0.010)$ & $(0.010)$ \\
Estimation & OLS & IV & OLS & IV \\
Instrument & & Log 2005 & & Log 2005 \\
& & FTHHI & FTHHI \\
Sample Years & $2005-2008$ & $2006-2008$ & $2005-2008$ & $2006-2008$ \\
Removed patients with any & & & X & X \\
$\quad$ cardiovascular treatment before AMI & & & & \\
Observations & 11,846 & 9,836 & 6,862 & 5,739
\end{tabular}

Notes: The dependent variable is the logarithm of service price, $\ln \left(P_{n}\right)$. All regressions include state-time fixed effects and controls specified in equation (5), see Appendix Table A1 for estimates of all covariates. Standard errors clustered by county are in parentheses. ${ }^{*} p<0.10,{ }^{* *} p<0.05,{ }^{* * *} p<0.01$.

\section{Empirical Results}

\subsection{Effect of Concentration on Price}

We display results of the first-stage estimation, equation (5), in Table 3. The first column reports the estimate of $\beta$ under the entire sample while the second column reports estimates under the sample of unexpected AMIs, defined as those episodes where the individual had no treated cardiological conditions and who received emergency room care on the day of the AMI. The third column shows estimates where we limit the sample to the years 2006 through 2008 and instrument the FTHHI with the 2005 FTHHI. Instrumenting the FTHHI with a lagged value of itself plausibly removes any contemporaneous relationship between the FTHHI and the unobservable $\varepsilon$ and helps address the attenuation bias discussed previously.

Estimates of $\beta$, the coefficient on the FTHHI, range between 0.038 and 0.045 , all statistically significant at the 1 percent level. This implies that a one-standard-deviation increase in the FTHHI causes about a 4 percentage point increase in service prices. ${ }^{37}$ The point estimate rises slightly when instrumenting with the 2005 FTHHI or estimating on

\footnotetext{
${ }^{37}$ The mean FTHHI is 0.16 and the standard deviation is 0.21 . Thus a one-standard-deviation increase in the FTHHI implies a price increase of $\exp (\beta * \ln (0.16+0.21)-\beta * \ln (0.16))-1$.
} 
Table 4: Effect of Cardiologist Service Price Change on Cardiologist RVUs

\begin{tabular}{lccccc} 
Outcome: & \multicolumn{5}{c}{ Log Cardiologist RVUs } \\
\hline \hline Log Cardiology Service Price & $-0.454^{* * *}$ & $1.403^{* * *}$ & $1.702^{* * *}$ & $1.314^{* *}$ & $1.482^{* * *}$ \\
& $(0.050)$ & $(0.472)$ & $(0.492)$ & $(0.549)$ & $(0.550)$ \\
Estimation & OLS & IV & IV & IV & IV \\
Instrument & & Log Current & Log 2005 & Log Current & Log 2005 \\
& & FTHHI & FTHHI & FTHHI & FTHHI \\
Sample Years & $2005-2008$ & $2005-2008$ & $2006-2008$ & $2005-2008$ & $2006-2008$ \\
Removed patients with any & & & & X & X \\
$\quad$ cardiovascular treatment before AMI & & & & & 5,739 \\
Observations & 11,846 & 11,846 & 9,836 &
\end{tabular}

Notes: The dependent variable is the logarithm of cardiologist RVUs over the 90 days following AMI. All regressions include state-time fixed effects and controls specified in equation (6), see Appendix Table A4 for estimates of all covariates. Standard errors clustered by county are in parentheses. ${ }^{*} p<0.10$, ${ }^{* *} p<0.05,{ }^{* * *} p<0.01$.

the smaller sample of unexpected AMI patients.

\subsection{Effect of Cardiologist Service Price on Cardiologist Service Utilization}

Tables 4 and 5 depict the estimates from the second-stage regression, where we regress the cardiologist's service price on two proxies of the cardiologist's service utilization: the logarithm of the number of RVUs (Table 4) and the logarithm of the number of procedures Table (5). The number of RVUs accounts for the intensity of the individual service, while the second measure is a simple count of the number of services.

The coefficient on the logarithm of the cardiologist's service price, $\gamma$, is negative and statistically significant under OLS, but turns positive and significant using the FTHHI as an instrumental variable. The negative coefficient under OLS is likely stemming from omitted-variable bias due to unobservable cost - unobservable marginal cost is positively correlated with price but negatively correlated with utilization. The price elasticity of supply, in terms of RVUs, ranges from 1.3 to 1.7 and is statistically significant. These estimates are in the range of those found by Clemens and Gottlieb [2014], who found a price elasticity of supply of 1.5 for all physicians. However, this estimate is slightly larger 
Table 5: Effect of Cardiologist Service Price Change on the Number of Cardiologist Procedures

(1)

Outcome:
(2)

Log Number of Cardiologist Procedures

$(5)$

\begin{tabular}{lccccc}
\hline \hline Log Cardiology Service Price & $-0.087^{* * *}$ & 0.377 & $0.476^{*}$ & 0.321 & 0.384 \\
& $(0.026)$ & $(0.277)$ & $(0.270)$ & $(0.314)$ & $(0.298)$ \\
Estimation & OLS & IV & IV & IV & IV \\
Instrument & & Log Current & Log 2005 & Log Current & Log 2005 \\
& & FTHHI & FTHHI & FTHHI & FTHHI \\
Sample Years & $2005-2008$ & $2005-2008$ & $2006-2008$ & $2005-2008$ & $2006-2008$ \\
$\begin{array}{l}\text { Removed patients with any } \\
\quad \text { cardiovascular treatment before AMI }\end{array}$ & & & & X & X \\
Observations & \multirow{2}{*}{11,846} & 11,846 & 9,836 & 6,862 & 5,739
\end{tabular}

Notes: The dependent variable is the logarithm of the number of cardiologist procedures over the 90 days following AMI. All regressions include state-time fixed effects and controls specified in equation (6), see Appendix Table A4 for estimates of all covariates. Standard errors clustered by county are in parentheses. ${ }^{*} p<0.10,{ }^{* *} p<0.05,{ }^{* * *} p<0.01$.

than theirs obtained for cardiac patients. Similar to Clemens and Gottlieb [2014], Table 5 shows no strong response in terms of the number of services.

\subsection{Effect of Cardiologist Concentration on Utilization}

Table 6 shows estimates of the direct effect of physician concentration on cardiologist service utilization-specification (7). The first two columns report estimates where we proxy utilization with RVUs, while columns 3 and 4 show estimates where we use a simple procedure count. Columns 5 and 6 depict results where the dependent variable is the amount of RVUs per procedure - a measure of the average intensity of the procedure used.

Under the full sample, a one standard deviation increase in the FTHHI causes a 5 percent increase in RVUs. The estimates are equivalent using the sample of unexpected AMIs. The estimates using the number of procedures and the average intensity of the procedure as the dependent variable paint a more vivid picture. Specifically, there is no strong effect of concentration on the number of procedures but there is a strong statistically significant effect on the average intensity of the procedure. Thus, an increase in concentration causes the cardiologists to perform more services in terms of the intensity of the procedure, rather 
Table 6: Effect of Cardiologist Concentration on Cardiologist Service Utilization

\begin{tabular}{lcc|cc|cc} 
& $(1)$ & $(2)$ & $(3)$ & $(4)$ & $(5)$ & $(6)$ \\
Outcome: & Log Cardiologist RVUs & Log Cardiologist Procedures & Log RVUs Per Procedure \\
\hline \hline Log FTHHI & $0.056^{* * *}$ & $0.054^{* * *}$ & 0.015 & 0.013 & $0.041^{* * *}$ & $0.041^{* * *}$ \\
& $(0.018)$ & $(0.021)$ & $(0.011)$ & $(0.012)$ & $(0.015)$ & $(0.016)$ \\
Removed patients with any & & $\mathrm{X}$ & & $\mathrm{X}$ & $\mathrm{X}$ \\
$\begin{array}{l}\text { cardiovascular treatment before AMI } \\
\text { Observations }\end{array}$ & 11,846 & 6,862 & 11,846 & 6,862 & 11,846 & 6,862
\end{tabular}

Notes: The dependent variable is the logarithm of cardiologist RVUs (columns 1 and 2), the logarithm of the number of cardiologist procedures (columns 3 and 4), and the logarithm of the number of RVUs per procedure over the 90 days following AMI. All regressions include state-time fixed effects and controls specified in equation (7), see Appendix Table A2 for estimates of all covariates. Standard errors clustered by county are in parentheses. ${ }^{*} p<0.10,{ }^{* *} p<0.05,{ }^{* * *} p<0.01$.

than the number of procedures. ${ }^{38}$

Table 7 shows estimates where the dependent variable is the use of a specific procedure or drug: any type of echocardiogram, MPI test, cardiovascular stress test, cardiac catheterization, angioplasty, or CABG ${ }^{39}$ Here we run a linear probability model where the left-hand-side variable is a dummy variable indicating if the patient received the type of procedure within 90 days of the heart attack. Recall that a catheterization is an intensive procedure performed by the cardiologist to obtain information about the severity of the heart attack, while echocardiograms, MPI tests, and cardiovascular stress tests are less intensive diagnostic procedures. After the results of the diagnostic procedures are revealed, an angioplasty or CABG may or may not be performed to treat the patient.

There is a positive response of catheterization to an increase in concentration, but a negative response of cardiovascular stress tests, MPI tests, and echocardiograms, albeit the latter is statistically insignificant. This result is consistent with the results in Table 6, where the cardiologist shifts to more intensive services. Here, an intensive diagnostic procedure (catheterization) is chosen instead, or in addition to, the less intensive diagnostic procedures. Once the diagnostic test is performed, the severity is known, there is likely less uncertainty as to whether further treatment should be provided. This may explain

\footnotetext{
${ }^{38}$ Note that these estimates also correspond to supply elasticity estimates. Specifically, they are approximately equal to the estimates found in Table $5, \beta$, multiplied by the supply elasticities, $\gamma$, found in Table 6. For instance, a 10 percent increase in concentration causes about a 0.4 percent increase in price, which translates to a about a 0.6 percent increase in RVU supply under a price elasticity of supply of 1.5 .

${ }^{39}$ See the Appendix B for the specific CPT codes used to determine these categories.
} 
Table 7: Effect of Cardiologist Concentration on Use of Specific Procedures

\begin{tabular}{lcccccc} 
& $(1)$ & $(2)$ & $(3)$ & $(4)$ & $(5)$ & $(6)$ \\
Outcome: & Any & Any & Any & Any Cardiac & Any & Any \\
& Echocardiogram & MPI Test & Stress Test & Catheterization & Angioplasty & CABG \\
\hline \hline Log FTHHI & -0.016 & $-0.025^{* * *}$ & $-0.036^{* * *}$ & $0.011^{* *}$ & 0.003 & 0.003 \\
& $(0.013)$ & $(0.010)$ & $(0.011)$ & $(0.005)$ & $(0.008)$ & $(0.006)$ \\
Observations & 6,862 & 6,862 & 6,862 & 6,862 & 6,862 & 6,862
\end{tabular}

Notes: Estimates taken over the sample where we removed patients with any cardiovascular services before AMI. The dependent variable is a dummy variable representing whether an echocardiogram (column 1), myocardial perfusion imaging test (column 2), stress test (column 3), catheterization (column 4), angioplasty (column 5), or CABG (column 6) was performed over the 90 days following AMI. See Appendix $\mathrm{B}$ for the specific CPT codes that apply to each procedure. All regressions include state-time fixed effects and controls specified in equation (7), see Appendix Table A3 for estimates of all covariates. Standard errors clustered by county are in parentheses. ${ }^{*} p<0.10,{ }^{* *} p<0.05,{ }^{* * *} p<0.01$.

why there is no response in angioplasty or CABG.

\subsubsection{Falsification Exercise}

In Table 8 we perform a type of falsification test in which we include episodes where a capitated payment was made to the cardiologist. Before dropping capitated episodes for our previous analysis, our sample included 513 episodes where a capitated payment was made (4 percent of all episodes). If the effect of concentration on service utilization is stemming from its effect on service prices, we would expect there to be no effect of the FTHHI on service use for episodes where capitated payments are made. In this specification, we include the 513 capitated episodes in our sample, as well as a corresponding dummy variable indicating whether the episode was capitated as well as an interaction the FTHHI variable. The implied effect of the FTHHI on utilization for capitated episodes is then the sum of the coefficient on the interaction (i.e., $\log (\mathrm{FTHHI})^{*}$ Capitated) and the coefficient on the FTHHI. Table 8 shows that there is no statistically significant effect of the FTHHI on service utilization for capitated episodes. ${ }^{40}$ The coefficient on the interaction term is negative, which implies the total effect on capitated episodes is smaller than fee-forservice episodes. Although there is a possibility that the statistically insignificant effect

\footnotetext{
${ }^{40}$ The total amount transacted for episodes involving capitated payments is unknown. Therefore, service prices may not be computed for these episodes.
} 
Table 8: Effect of Cardiologist Concentration on Cardiologist Service Utilization: Difference-in-Differences with Capitated Episodes

\begin{tabular}{lcc} 
& $(1)$ & $(2)$ \\
\hline \hline Log FTHHI & $0.056^{* * *}$ & $0.055^{* * *}$ \\
(Log FTHHI ${ }^{*}$ Capitated & $(0.017)$ & $(0.020)$ \\
Capitated & -0.040 & -0.015 \\
& $(0.028)$ & $(0.031)$ \\
Implied Log FTHHI + (Log FTHHI $)^{*}$ Capitated & -0.084 & -0.098 \\
& $(0.085)$ & $(0.101)$ \\
Removed patients with any & $(0.030)$ & $(0.035)$ \\
cardiovascular treatment before AMI & & X \\
Observations & 12,357 & 7,135
\end{tabular}

Notes: The dependent variable is the logarithm of cardiologist RVUs over the 90 days following AMI. These samples are larger because they include capitated episodes. All regressions include state-time fixed effects and controls specified in equation (7). Standard errors clustered by county are in parentheses.

on capitated episodes may in part be due to sample size issues, this exercise gives some credence to the idea that the effect of physician concentration on service provision comes through, at least partially, via service prices.

\subsection{Effect of Cardiologist Concentration on Expenditures}

The study thus far has estimated the effect of cardiologist concentration on services specifically provided by the cardiologist. Concentration affects both the service price as well as the cardiologist's service utilization, the two components of cardiologist expenditures. As shown in Table 1, cardiology services represent only a fraction of total services performed over the 90-day episode of care. However, since the cardiologist is the primary decision maker in terms of types of care, it is possible that a change in the cardiologist's market power might impact the total cost of treating a heart attack more broadly.

To examine the impact on the total cost of treating a heart attack, Table 9 reports estimates of the impact of cardiologist concentration total expenditures, as well as the impact on cardiologist and noncardiologist expenditures. Specifically, total expenditures are simply the sum of payments over the entire 90 days following the AMI. The latter two measures split these payments into two mutually exclusive buckets.

Estimates show that higher cardiologist market concentration has a statistically signif- 
Table 9: Effect of Cardiologist Concentration on Expenditures

\begin{tabular}{|c|c|c|c|c|c|c|c|c|}
\hline \multirow[b]{2}{*}{ Outcome: } & (1) & $(2)$ & $(3)$ & $(4)$ & $(5)$ & (6) & (7) & (8) \\
\hline & \multicolumn{2}{|c|}{$\begin{array}{c}\text { Log Total } \\
\text { Expenditures }\end{array}$} & \multicolumn{2}{|c|}{$\begin{array}{l}\text { Log Cardiologist } \\
\text { Expenditures }\end{array}$} & \multicolumn{2}{|c|}{$\begin{array}{l}\text { Log Non-Cardiologist } \\
\text { Expenditures }\end{array}$} & \multicolumn{2}{|c|}{$\begin{array}{c}\text { Share Cardiologist } \\
\text { Expenditures }\end{array}$} \\
\hline Log FTHHI & $\begin{array}{c}0.002 \\
(0.016)\end{array}$ & $\begin{array}{c}0.006 \\
(0.019)\end{array}$ & $\begin{array}{c}0.094^{* * *} \\
(0.022)\end{array}$ & $\begin{array}{c}0.094^{* * *} \\
(0.025)\end{array}$ & $\begin{array}{l}-0.002 \\
(0.018)\end{array}$ & $\begin{array}{c}0.000 \\
(0.021)\end{array}$ & $\begin{array}{l}0.004^{*} \\
(0.002)\end{array}$ & $\begin{array}{l}0.004^{* *} \\
(0.002)\end{array}$ \\
\hline $\begin{array}{l}\text { Removed patients with any } \\
\text { cardiovascular treatment before AMI }\end{array}$ & & $\mathrm{X}$ & & $\mathrm{X}$ & & $\mathrm{X}$ & & $\mathrm{X}$ \\
\hline Observations & 11,846 & 6,862 & 11,846 & 6,862 & 11,846 & 6,862 & 11,846 & 6,862 \\
\hline
\end{tabular}

Notes: The dependent variable is the logarithm of total expenditures (columns 1 and 2), the logarithm of cardiologist expenditures (columns 3 and 4), the logarithm of non-cardiologist expenditures (columns 5 and 6), and the share of total expenditures paid to the cardiologist (columns 7 and 8) over the 90 days following AMI. All regressions include state-time fixed effects and controls specified in equation (7). Standard errors clustered by county are in parentheses. ${ }^{*} p<0.10,{ }^{* *} p<0.05,{ }^{* * *} p<0.01$.

icant effect on cardiologist expenditures (columns 3 and 4 of Table 9) - a one-standarddeviation increase in concentration causes about an 8 percent increase in expenditures. This effect is attributable to the 3 percent effect of concentration on prices (Table 3) as well as the 5 percent effect on service utilization (Table 6). Higher cardiologist market concentration has no statistically significant effect on noncardiologist expenditures or total AMI expenditures. This latter result may be due to the fact that that the share of total AMI expenditures going to the cardiologist expenditures is small (9 percent). Overall, higher cardiologist concentration raises the share of total expenditures going to the cardiologist (columns 7 and 8 of Table 9).

\subsection{Effect of Cardiologist Concentration on Health Outcomes}

Our final analysis examines the impact of cardiologist concentration on health outcomes. It is not clear, a priori, whether market power should have any definitive effect on the health of the patient. On one hand, the higher price stemming from market concentration may allow the cardiologist to exert more effort or perform necessary tests and procedures. On the other hand, the additional procedures may not be necessary or may be excessive in terms of treating the patient. In addition, less competition between physicians may imply less pressure to compete along the quality dimension. To examine the impact of concentration on health outcomes, we use two measures of adverse health outcomes: whether the patient died in the hospital, and whether the patient was readmitted with 
Table 10: Effect of Cardiologist Concentration on Death in Hospital

\begin{tabular}{|c|c|c|c|c|}
\hline & (1) & $(2)$ & $(3)$ & (4) \\
\hline & \multicolumn{2}{|c|}{ within 90 days } & \multicolumn{2}{|c|}{ within 365 days } \\
\hline \multirow[t]{2}{*}{ Log FTHHI } & -0.001 & 0.001 & -0.002 & -0.002 \\
\hline & $(0.001)$ & $(0.001)$ & $(0.001)$ & $(0.002)$ \\
\hline \multicolumn{5}{|l|}{ Removed patients with any } \\
\hline cardiovascular treatment before AMI & & $\mathrm{X}$ & & $\mathrm{X}$ \\
\hline Observations & 11,134 & 6,444 & 11,134 & 6,444 \\
\hline
\end{tabular}

Notes: The dependent variable is a dummy indicating whether the patient's discharge status indicated death within 90 days of the AMI (columns 1 and 2) and within 365 days of the AMI (columns 3 and 4). All regressions include state-time fixed effects and controls specified in equation (7). Standard errors clustered by county are in parentheses. ${ }^{*} p<0.10,{ }^{* *} p<0.05,{ }^{* * *} p<0.01$.

complications.

For a large portion of the MarketScan database there is information about the discharge status of the patient. This means that, for those observations where a discharge status is available, we have information about whether the patient died in the hospital. Using this discharge status variable, we create a dummy variable indicating whether the patient died in the hospital within 90 days of the AMI (see Table 1) and another variable whether the patient died in the hospital within 365 days after the AMI. As described in Section 3, the data show that 0.3 percent of individuals in the full sample and 0.2 percent of individuals in the unexpected AMI sample had a death status at discharge. ${ }^{41}$ Readmission is measured as whether the patient returned to the hospital for complications due to AMI, as well as any cardiovascular condition, between 90 and 365 days after the AMI.

Estimates of specification (7), using a dummy variable indicating death within 90 days of the AMI as the dependent variable, are reported in the first two columns of Table 10. The results are statistically insignificant. Table 11 shows the impact on readmission rates, indicating that cardiologist concentration decreases the probability that the patient is readmitted for AMI. The effect for readmission for any cardiovascular condition are statistically insignificant. Overall, these estimates provide strong evidence that market power does not lead to worse health outcomes. The results on readmissions show that higher concentration may even lead to improved health outcomes.

\footnotetext{
${ }^{41}$ These rates would be much larger if we included those individuals who died the same day the AMI occurred -2.1 and 1.5 percent, respectively.
} 
Table 11: Effect of Cardiologist Concentration on Readmission to Hospital

(1)

Outcome:

$\underline{\text { Readmission to hospital, } 90 \text { to } 365 \text { days }}$

\begin{tabular}{lcc|lc} 
& \multicolumn{2}{c|}{ for } & \multicolumn{2}{c}{ for any } \\
& \multicolumn{2}{c}{ AMI } & cardiovascular condition \\
\hline Log FTHHI & $-0.002^{* *}$ & $-0.002^{* *}$ & -0.000 & -0.005 \\
& $(0.001)$ & $(0.001)$ & $(0.004)$ & $(0.004)$ \\
Removed patients with any & & & & \\
$\quad$ cardiovascular treatment before AMI & & $\mathrm{X}$ & & $\mathrm{X}$ \\
Observations & 11,846 & 6,862 & 11,846 & 6,862
\end{tabular}

Notes: The dependent variable is a dummy indicating whether the patient was readmitted for AMI between 90 and 365 days of the AMI (columns 1 and 2) and readmitted for any cardiovascular disease between 90 and 365 days of the AMI (columns 3 and 4). All regressions include state-time fixed effects and controls specified in equation (7). Standard errors clustered by county are in parentheses. ${ }^{*} p<0.10,{ }^{* *} p<0.05$, ${ }^{* * *} p<0.01$.

\section{Conclusion}

This study shows that physician market power not only affects payment rates, but also service utilization. We estimate that a one-standard-deviation increase in cardiologist concentration causes a 3 percent increase in payments, but also a 5 percent increase in service provision by the cardiologist. This results in an expenditure increase of approximately 8 percent. Market power impacts the type of procedure rather than the number of procedures. Specifically, cardiologists in more concentrated markets perform more intensive procedures, particularly diagnostic procedures. Evidence from the difference-in-differences specification using capitated episodes leads us to believe that the impact of physician market power on service utilization is through the effect of market power on the physician's reimbursement rate, similar to other studies finding a link between financial incentives and treatment decisions. We were surprised to find that concentration may lead to lower readmission rates, although the mechanism as to how or why this happens is not clear to us.

A limitation of our study is that we identify variation in treatment decisions across observed geographic differences in concentration, as opposed to random differences. To be clear, we cannot entirely be sure that our results are not being driven by omitted variables, unrelated to market structure that are spuriously correlated with both our FTHHI measure 
and cardiologist service use. However, we show that unobserved cost and health severity variation would likely bias our results against the findings in this study. That is, the main qualitative result in this study is not likely to be impacted by these types of omitted variable biases. This leads us to believe that our estimates may underestimate the true impact of concentration on utilization. An avenue for future research would be to exploit time-series variation in physician concentration, although, we note that this type of variation is also not immune to similar types of endogeneity concerns.

Overall, our findings are potentially important for antitrust analysis and suggest that changes in organization structure in a market, such as a merger of physician groups, not only influences the negotiated prices of services, but also the utilization of medical treatments. Our main estimates imply that over half of the impact of concentration on expenditures is through quantity as opposed to price.

\section{References}

[1] Acemoglu, Daron and Amy Finkelstein. 2008. "Input and Technology Choices in Regulated Industries: Evidence From the Health Care Sector." Journal of Political Economy. 116(5).

[2] Altman, Daniel, David M. Cutler, Richard Zeckhauser. 2003. "Enrollee Mix, Treatment Intensity, and Cost in Competing Indemnity and HMO plans." Journal of Health Economics. 22(1) 23-45.

[3] Baker, Laurence C. 2010. "Acquisition of MRI Equipment By Doctors Drives up Imaging Use And Spending" Health Affairs. 29(12), 2252-2259.

[4] Baker, Laurence C., M. Kate Bundorf, Anne B. Royalty, and Zachary Levin. 2014. "Physician Practice Competition and Prices Paid by Private Insurers for Office Visits." The Journal of the American Medical Association. 312(16). 1653-1662.

[5] Berenson, Robert A., Paul B. Ginsburg and Nicole Kemper. 2010. "Unchecked Provider Clout In California Foreshadows Challenges to Health Reform." Health Affairs. 29(4) 699-705.

[6] Chandra, Amitabh, Jonathan Gruber, and Robin McKnight. 2010. "Patient CostSharing and Hospitalization Offsets in the Elderly. American Economic Review 100(1): 19321 
[7] Chandra, Amitabh, and Jonathan S. Skinner. 2012. "Technology Growth and Expenditure Growth in Health Care." Journal of Economic Literature 50(3): 645-80.

[8] Clemens, Jeffrey C. and Joshua D. Gottlieb. 2014. "Do Physicians' Financial Incentives Affect Medical Treatment and Patient Health?" American Economic Review. 104(4) 1320-49.

[9] Clemens, Jeffrey C., Joshua D. Gottlieb, and Adam Hale Shapiro. 2014. "How Much Do Medicare Cuts Reduce Inflation?" Federal Reserve Bank of San Francisco Economic Letter.

[10] Coey, Dominic. 2014. "Physicians' Financial Incentives and Treatment Choices in Heart Attack Management." Quantitative Economics, forthcoming.

[11] Cutler, David M., Mark McClellan, and Joseph P. Newhouse. 1998a. "What has increased medical-care spending bought?" American Economic Review: Papers and Proceedings, 88(2) 132-136

[12] Cutler, David M., Mark McClellan, and Joseph P. Newhouse. 1998b. "Are Medical Prices Declining? Evidence from Heart Attack Treatments" Quarterly Journal of Economics , 113(4) 991-1024.

[13] Cutler, David M., Mark McClellan, and Joseph P. Newhouse. 2000. "How Does Managed Care Do It?" RAND Journal of Economics. 31(3). 526-548.

[14] Decker, Sandra L. 2009. "Changes in Medicaid Physician Fees and Patterns of Ambulatory Care.' Inquiry Vol. 46, No. 3, pp. 291-304

[15] Dunn, Abe, and Adam Hale Shapiro. 2014. "Do Physicians Possess Market Power?" The Journal of Law and Economics. Vol. 57, No. 1. pp. 159-193.

[16] Dunn, Abe and Adam Hale Shapiro. 2015. "Physician Payments Under Health Care Reform." Journal of Health Economics. Vol. 39, pp. 89-105.

[17] Dunn, Abe, Adam Hale Shapiro, and Eli Liebman. 2013. "Geographic Variation in Commercial Medical Care Expenditures: A framework for decomposing price and utilization." Journal of Health Economics. Vol. 32. Issue 6. pp. 1153-1165.

[18] Finkelstein, Amy. 2007. "The Aggregate Effects of Health Insurance." Quarterly Journal of Economics 122(1), 1-37. 
[19] Godager, Geir, Tor Iversen, and Ching-to Albert Ma. 2015. "Competition, gatekeeping, and health care access." The Journal of Health Economics. Vol. 39. pp 159-170.

[20] Grant, Darren. 2009. "Physician Financial Incentives and Cesarean Delivery: New Conclusions From the Healthcare Cost and Utilization Project." Journal of Health Economics.

[21] Gravelle, Hugh, Anthony Scott, Peter Sivey, and Jognsay Yong. 2015. "Competition, Prices and Quality in the Market for Physician Consultations." Journal of Industrial Economics

[22] Gruber Jon, and Maria Owings. 1996. "Physician Financial Incentives and the Diffusion of Cesarean Section Delivery." RAND Journal of Economics 27(1). p.99-123

[23] Gruber, Jon, John Kim, and Dina Mayzlin. 1999. "Physician Fees and Procedure Intensity: The case of Cesarean Delivery." Journal of Health Economics. 18(4) 473490.

[24] Kleiner, Samuel A., William D. White, and Sean Lyons. 2015. "Market Power and Provider Consolidation in Physician Markets." International Journal of Health Economics Management. 15. 99-126.

[25] Hemenway, David, Alice Killen, Suzanne B. Cashman, Cindy Lou Parks, and Willam J. Bicknell. 1990. "Physicians' Responses to Financial Incentives-Evidence from a for-Profit Ambulatory Care Center." The New England Journal of Medicine. 322 (15), 1059-1063,

[26] Hillman, Alan L., Mark V. Pauly and Joseph J. Kerstein. 1989. "How do Financial Incetives Affect Physicians' Clinical Decisions and the Financial Performance of Health Maintenance Organizations?" The New England Journal of Medicine. 321(2), 86-92.

[27] Iglehart, John K. 2005. "The Emergence of Physician-Owned Specialty Hospitals." The New England Journal of Medicine.

[28] Johnson, Erin M., and M. Marit Rehavi. 2015. "Physicians Treating Physicians: Information and Incentives in Childbirth." American Economic Journal: Economic Policy, forthcoming.

[29] Keeler, Emmett and John Rolph. 1988. "The Demand for Episodes of Treatment in the Health Insurance Experiment." Journal of Health Economics. 7(4) pgs 337-367. 
[30] Keeley, Ellen C. and Cindy L. Grines. 2004. "Primary Percutaneous Coronary Intervention for Every Patient with ST-Segment Elevation Myocardial Infarction: What Stands in the Way?" Annals of Internal Medicine. 141(4).

[31] Kessler, Daniel P., and Mark B. McClellan. 2000. "Is Hospital Competition Socially Wasteful?", The Quarterly Journal of Economics, 115(2), pp. 577-615

[32] Li, Jinhu, Jeremhia Hurley, Philip DeCicca and Gioia Buckley. 2014. "Physician Response to Pay-for-Performance: Evidence from a Natural Experiment." Health Economics. Vol. 23(8). pp. 962-978.

[33] McGuire, Thomas G., and Mark V. Pauly. 1991. "Physicain Response to Fee Changes with Multiple Payers." Journal of Health Economics. 10(4), 385-410.

[34] Popescu, Ioana, Mary S. Vaughan-Sarrazin and Gary E. Rosenthal. 2007. "Differences in Mortality and Use of Revascularization in Black and White Patients With Acute MI Admitted to Hospitals With and Without Revascularization Services." The Journal of the American Medical Association. 297 (22).

[35] Rebitzer, James B. and Mark E. Votruba. 2011. "Organizational Economics and Physician Practices", Working Paper 17535, NBER Working Paper Series.

[36] Reinhardt, Uwe. 2006. "The Pricing of U.S. Hospital Services: Chaos Behind a Veil of Secrecy", Health Affairs 25(1), 57-69. Series.

[37] Robinson, James C. and Kelly Miller. 2014. "Total Expenditures per Patient in Hospital-Owned and Physician Organizations in California." The Journal of the American Medical Association. 312(16)

[38] Sachdeva, Amit et al. 2009 "Lipid levels in patients hospitalized with coronary artery disease: An analysis of 136,905 hospitalizations in Get With The Guidelines." American Heart Journal , 157(1). $111-117$

[39] Smart, D.R. 2006. Medical group practices in the U.S., 2006 edition. Chicago, IL: American Medical Association.

[40] Spetz, Joanne, Mark Smith, and Sean Ennis. 2001. "Physician Incentives and the Timing of Cesarean Sections: Evidence From California." Medical Care. 39(6) 536550. 


\section{Appendix}

\section{A Construction of AMI Sample from MarketScan Data}

In this appendix, we discuss our methods and assumptions involved in constructing our sample of first-time AMI patients from the MarketScan data. We begin with the full 2004 to 2009 MarketScan sample. We then kept only those enrollees who experienced an acute myocardial infarction (AMI). This was done by keeping only those enrollees who had at least one service line with an ICD-9 code beginning with "410."

For each enrollee, we recorded the date the first time an ICD-9 beginning with 410 occurred. We then kept those enrollees whose first AMI (ICD-9 beginning with 410) occurred in 2005 through 2008. ${ }^{42}$ We then scrolled up the services that occurred the 90 days following the date of the first AMI. We created flags indicating where possible errors or outliers occur. We dropped episodes based on the following criteria:

\section{- Likely Errors}

- MarketScan cannot identify provider type.

- The episode included a missing procedure code.

- The episode included a negative payment. ${ }^{43}$

- Focus on cardiologists practicing in one county

- Services were provided by cardiologists from more than one county.

- The episode did not include services provided by a cardiologist ( tdprov $=250$ ).

- Episodes that were possibly not first-time AMI (or the patient possibly had knowledge of AMI).

- The enrollee was not admitted to an emergency room or did not receive any emergency services on the day of the AMI.

\footnotetext{
${ }^{42}$ This means that for those patients whose first AMI appeared in 2005 we only know if the enrollee did not have an AMI in 2004. For those enrollees whose first AMI was in 2008, we know they did not experience an AMI from 2004 through 2007.

${ }^{43}$ This is not necessarily an error by MarketScan as it usually indicates a service removed from a bill.
} 
- The enrollee received inpatient or outpatient medical treatment the day before the AMI.

- The enrollee did not appear in the enrollee file the year before the AMI.

- MarketScan's medical-episode grouper (MEG) indicated an AMI occurred prior to a reported ICD-9 "410."

- The episode's primary diagnosis AMI ICD-9 code ended with "2." A fifth digit equal to 2 indicates "subsequent episode of care."

- Outliers

- The episode included a capitated plan.

- The enrollee was age 64 and over.

- The enrollee's inpatient stay was longer than 30 days.

- The enrollee was not admitted to the hospital (inpatient stay shorter than 2 days).

- The enrollee died on the day of the AMI.

- The cardiologist billed for less than two services.

- Total expenditures over the course of the episode was greater than the 99th percentile (performed at end of cleaning).

- Total expenditures over the course of the episode was less than the 1st percentile (performed at end of cleaning).

- The number of cardiologist RVUs over the course of the episode was greater than the 99th percentile (performed at end of cleaning).

- The number of cardiologist RVUs over the course of the episode was less than the 1st percentile (performed at end of cleaning).

- The price of the episode was greater than the 99th percentile (performed at end of cleaning).

- The price of the episode was less than the 1st percentile (performed at end of cleaning).

To create the sample of "unexpected" AMIs, we dropped episodes based on the following additional criterion: 
- The enrollee was treated for a cardiovascular condition within 365 days prior to the AMI. We define a cardiovascular condition as a service either provided by a cardiologist or ICD-9 code between 390 and 459. 


\section{B Definition of Procedure Variables}

CPT Codes:

- Cardiac Catheterization: 93501-93572

- Angioplasty: 35450,35452, 35454, 35456, 35458, 35459-35476, 37205, 37206, 37215, 37216, 37221, C1876, C1884, 61630, 92980-92984,92997,92998, 75962-75968, 75978

- CABG: $33500-33545,33548,35600$

- Echocardiogram: 93300-93350, 76825, 76826, 76828, 93662

- Cardiovascular Stress Test: 93015-93018, 93024

- Myocardial Perfusion Imaging: 78400-78499 


\section{Top 20 CPT Codes Among Cardiologists Treating AMI}

Frequency

CPT in Raw Data Percent

$93010 \quad 33,611$

10.4 Electrocardiogram, routine ECG with at least 12 leads; interpretation and report only

$99232 \quad 20,661$ focused examination; Medical decision making of moderate complexity. Counseling and/or coordination of care with other physicians, other qualified health care professionals, or agencies are provided consistent with the nature of the problem(s) and the patient's and/or family's needs. Usually, the patient is responding inadequately to therapy or has developed a minor complication. Typically, 25 minutes are spent at the bedside and on the patient's hospital floor or unit.

$93545 \quad 17,641 \quad 5.46$ Injection procedure during cardiac catheterization; for selective coronary angiography (injection of radiopaque material may be by hand)

9355617,512

5.42 Imaging supervision, interpretation and report for injection procedure(s) during cardiac catheterization; pulmonary angiography, aortography, and/or selective coronary angiography including venous bypass grafts and arterial conduits (whether native or used in bypass)

$93510 \quad 16,356$

5.06 Left heart catheterization, retrograde, from the brachial artery, axillary artery or femoral artery; percutaneous

$93543 \quad 15,554 \quad 4.81$ Injection procedure during cardiac catheterization; for selective left ventricular or left atrial angiography

9355515,439

13,093

4.78 Imaging supervision, interpretation and report for injection procedure(s) during cardiac catheterization; ventricular and/or atrial angiography

4.05 Echocardiography, transthoracic, real-time with image documentation (2D) with or without M-mode recording; complete

4.03 Doppler echocardiography, pulsed wave and/or continuous wave with spectral display; complete

4.00 Doppler echocardiography color flow velocity mapping

3.7 Transcatheter placement of an intracoronary stent(s), percutaneous, with or without other therapeutic intervention, any method; single vessel

3.37 Office or other outpatient visit for the evaluation and management of an established patient, which requires at least 2 of these 3 key components

making of modersecomplext. Counseing and/or coordinaton of care with other physcians, other qualfied health care profes and the patient's and/orfamily's needs. Usually, the presenting problem(s) are of moderate to high sevetiry. Typically, 25 minutes are spent face-to-face with the patient and/or family

3.07 Office or other outpatient visit for the evaluation and management of an established patient, which requires at least 2 of these 3 key components: An expanded problem focused history; An expanded problem focused examination; Medical decision making of low complexity. Counseling and coordination of care with other physicians, other qualified health care professionals, or agencies are provided consistent with the nature of the problem(s) and the patient's and/or family's needs. Usually, the presenting problem(s) are of low to moderate severity. Typically, 15 minutes are spent face-to-face with the patient and/or family making of high complexity. Counseling and/or coordination of care with other physicians, other qualified health care professionals, or agencies are provided consistent with the nature of the problem(s) and the patient's and/or family's needs. Usually, the patient is unstable or has developed a significant complication or a significant new problem. Typically, 35 minutes are spent at the bedside and on the patient's hospital floor or unit

$93000 \quad 9,588$

297 Electrocardiogram, routine ECG with at least 12 leads; with interpretation and report

99238

2.47 Hospital discharge day management; 30 minutes or less

99223

2.21 Initial hospital care, per day, for the evaluation and management of a patient, which requires these 3 key components; A comprehensive history; A comprehensive examination; and Medical decision making of high complexity. Counseling and/or coordination of care with other physicians, other qualified health care professionals, or agencies are provided consistent with the nature of the problem(s) and the patient's and/or family's needs. Usually, the problem(s) requiring admission are of high severity. Typically, 70 minutes are spent at the bedside and on the patient's hospital floor or unit

1.63 Subsequent hospital care, per day, for the evaluation and management of a patient, which requires at least 2 of these 3 key components: A problem focused interval history; A problem focused examination; Medical decision making that is straightforward or of low complexity. Counseling and/or coordination of care with other physicians, other qualified health care professionals, or agencies are provided consistent with the nature of the problem(s) and the patient's and/or family's needs. Usually the patient is stable, recovering or improving. Typically, 15 minutes are spent at the bedside and on the patient's hospital floor or unit

1.37 Cardiovascular stress test using maximal or submaximal treadmill or bicycle exercise, continuous electrocardiographic monitoring, and/or pharmacological stress; with physician supervision, with interpretation and report 


\section{Construction of FTHHI from SK\&A Data}

We will label our physician concentration measure a "fixed-travel-time" HHI (FTHHI) because it is based on the assumption of a market boundary defined by a fixed driving time. ${ }^{44}$ There is a four-step process in creating the FTHHI. First, we define a geographic market boundary. Second, we calculate the probability that a person located within the market boundary will visit a physician firm. This step is crucial as we are calculating probabilities based solely on information about the distance between people and physicians. Third, using the probabilities of seeing each physician calculated in step two, we calculate expected market shares. Fourth, using these expected market shares and physician group information, we construct concentration measures specific to a county and time period.

\section{Defining the Market Boundary}

We define the market boundary as a geographic distance surrounding a given patient, as would be done in a standard Hotelling problem. Since the most granular U.S. population data are at the census-tract level, we define market boundaries as fixed distances surrounding the centroid of each census tract. That is, our assumption is that all people reside at the census-tract centroid and the market boundary is defined as the maximum amount

of driving time, $\bar{k}$, a person would be willing to travel to a physician firm. ${ }^{45}$ Specifically, for each census tract's centroid geographic location, we define a latitude and longitude location as a vector $x=\{l a t, l o n g\}$. Using Google's Maps software, we can measure a maximum radial distance surrounding the centroid based on specific length of driving time $\bar{k}^{46}$ We set $\bar{k}$ equal to 80 minutes. Note that in Dunn and Shapiro [2014] we created four

\footnotetext{
${ }^{44}$ It is important to note that this is calculated in similar fashion to Kessler and McClellan [2000] in that they are based solely on information about the physician's group size and distance to patients. The concentration measures we construct therefore do not include any information about the physician firms' actual shares which may be tainted with information about the quality of the physician firm. While it would be interesting to compare our measures to an HHI based on actual market shares, we cannot construct such a measure using the MarketScan ${ }^{\circledR}$ data. Although there does exist a "provider ID" in the MarketScan ${ }^{\circledR}$ data, this variable is coded by the data contributors, not Thomson Reuters. Therefore we use caution when applying the provider ID variable since distinct data contributors may assign different IDs to the same provider.

${ }^{45}$ Driving times were calculated in Stata using the 'traveltime' command developed by Ozimek and Miles. This command finds the driving time between two latitude and longitude points via Google maps. ${ }^{46} \mathrm{To}$ do so, for each county, $c$, we drew a random coordinate and then calculated the average speed, speed $_{c}$, one could travel 0.1 degrees north, south, east, and west latitude. We use the Stata package, "traveltime," written by Ozimek and Miles. This allows us to define a maximum radial distance for any latitude and longitude coordinate in county $c$ as $\bar{k} *$ speed $_{c}$.
} 
different FTHHI measures using $\bar{k}$ equal to 20, 40, 60, and 80 minutes.

\section{Calculating the probability of a patient visiting a physician}

To capture the idea that, all else equal, a consumer would rather receive medical care from a physician who resides closer to his or her residence, we assume that consumers earn negative utility for each extra minute of travel time to the physician. The probability of whether a patient located at census-tract centroid $x_{0}$ would be willing to travel to a physician located at $x_{i}$ will be based on the travel time between them. For a patient located at $x_{0}$, we define their driving time to a physician located at $x_{i}$ as $k_{x_{i}}{ }^{47}$

We create a variable which represents the probability that a patient located at $x_{0}$ would consider traveling to the physician located at $x_{i}$. We do this in the most tractable manner possible by assuming that patients' idiosyncratic taste shocks lie on the uniform distribution and that $k_{x_{i}}$ is directly proportional to travel costs. Specifically, a patient will choose a physician located at $x_{i}$ instead of a physician located at $x_{0}$ if $V-k_{x_{i}}+\varepsilon_{i 0}>V-k_{x_{0}}$ where $V$ is the patient valuation of treatment and $\varepsilon_{i 0}$ is a patient taste shock of traveling from $x_{i}$ to $x_{0}$, which lies on the uniform distribution between 0 and $\bar{k}$. As $k_{x_{0}}=0$ by construction, it follows that a patient located at $x_{0}$ would be willing to travel to $x_{i}$ (that is, travel $k_{x_{i}}$ minutes) with probability:

$$
\operatorname{Pr}\left(\varepsilon_{i 0}>k_{x_{i}}\right)= \begin{cases}1-(1 / \bar{k}) k_{x_{i}} & \text { if } \quad k_{x_{i}} \leq \bar{k} \\ 0 & \text { if } \quad k_{x_{i}}>\bar{k}\end{cases}
$$

\section{Constructing Expected Market Shares}

The probability that a patient located at centroid $x_{0}$ visits a physician located at $x_{i}$ is treated as the quantity of patients from $x_{0}$ expected to visit a single physician located at $x_{i}$. This means the expected market share of a single physician located at $x_{i}$ for patients located at census-tract centroid $x_{0}$ is $E\left[S_{x_{i}}\left(x_{0}\right)\right]=\frac{\operatorname{Pr}\left(\varepsilon_{i 0}>k_{x_{i}}\right)}{\sum_{j} \operatorname{Pr}\left(\varepsilon_{j 0}>k_{x_{j}}\right)}$ where $j$ indexes each physician in the database. It follows that the expected market share at centroid $x_{0}$ for a physician group located at $x_{i}$ that has $N_{i}$ physicians is $E\left[S_{x_{i}}^{*}\left(x_{0}\right)\right]=\frac{N_{i} \operatorname{Pr}\left(\varepsilon_{i 0}>k_{x_{i}}\right)}{\sum_{j} N_{j} \operatorname{Pr}\left(\varepsilon_{j 0}>k_{x_{j}}\right)}$. Intuitively, one can think of the probability measure that declines with distance as assigning a lower weight to those physicians who compete from a more distant location. In other words, the more distant physicians may be considered weaker competitors.

\section{Construct Concentration Measures}

\footnotetext{
${ }^{47}$ It follows that a patient who lives at location $x_{0}$ resides $k_{x_{i}}$ minutes away from the physician located at $x_{i}$.
} 
We first calculate a "fixed-travel-time HHI" at the census tract level, FTH $H I_{h t}$, and then aggregate to construct an FTHHI at the county level, FTHHI $I_{c t}$. Specifically, for each census-tract with centroid geocode, $x_{h}$, we calculate a distinct FTHHI $I_{h t}=\sum_{i} E\left[S_{x_{j}}^{*}\left(x_{h}\right)\right]^{2}$ based on the expected market shares at census-tract centroid $x_{h}$. We then create a fixedtravel time concentration measure for the county, FTHHI $I_{c t}$, as the weighted sum of the FTH H I It measures, where the weights are the proportion of the county's population from the given census tract. 


\section{Additional Tables}

Table A1: Log Service Price

\begin{tabular}{|c|c|c|c|c|}
\hline $\begin{array}{l}\text { Outcome } \\
\text { Estimation } \\
\text { Sample }\end{array}$ & $\begin{array}{c}\text { Log Price } \\
\text { OLS } \\
\text { Full }\end{array}$ & $\begin{array}{c}\text { Log Price } \\
\text { IV } \\
\text { Full }\end{array}$ & $\begin{array}{c}\text { Log Price } \\
\text { OLS } \\
\text { Unexp. }\end{array}$ & $\begin{array}{c}\text { Log Price } \\
\text { IV } \\
\text { Unexp. }\end{array}$ \\
\hline $\ln \left(F T H H I_{p h y s}\right)$ & $\begin{array}{c}0.038^{* * *} \\
(0.009)\end{array}$ & $\begin{array}{c}0.042^{* * *} \\
(0.009)\end{array}$ & $\begin{array}{c}0.040^{* * *} \\
(0.010)\end{array}$ & $\begin{array}{c}0.045^{* * *} \\
(0.010)\end{array}$ \\
\hline Age 41 to 45 & $\begin{array}{c}0.029 \\
(0.030)\end{array}$ & $\begin{array}{c}0.066^{* *} \\
(0.031)\end{array}$ & $\begin{array}{c}0.041 \\
(0.036)\end{array}$ & $\begin{array}{c}0.091 * * \\
(0.037)\end{array}$ \\
\hline Age 46 to 50 & $\begin{array}{c}0.018 \\
(0.023)\end{array}$ & $\begin{array}{c}0.033 \\
(0.022)\end{array}$ & $\begin{array}{c}0.008 \\
(0.031)\end{array}$ & $\begin{array}{c}0.029 \\
(0.029)\end{array}$ \\
\hline Age 51 to 55 & $\begin{array}{c}0.016 \\
(0.024)\end{array}$ & $\begin{array}{l}0.041^{*} \\
(0.024)\end{array}$ & $\begin{array}{c}0.005 \\
(0.030)\end{array}$ & $\begin{array}{c}0.038 \\
(0.028)\end{array}$ \\
\hline Age 56 & $\begin{array}{c}0.028 \\
(0.029)\end{array}$ & $\begin{array}{c}0.057^{* *} \\
(0.029)\end{array}$ & $\begin{array}{c}0.002 \\
(0.037)\end{array}$ & $\begin{array}{c}0.038 \\
(0.034)\end{array}$ \\
\hline Age 57 & $\begin{array}{c}0.007 \\
(0.028)\end{array}$ & $\begin{array}{c}0.037 \\
(0.029)\end{array}$ & $\begin{array}{l}-0.002 \\
(0.043)\end{array}$ & $\begin{array}{c}0.049 \\
(0.041)\end{array}$ \\
\hline Age 58 & $\begin{array}{c}0.033 \\
(0.028)\end{array}$ & $\begin{array}{c}0.065^{* *} \\
(0.030)\end{array}$ & $\begin{array}{c}0.009 \\
(0.035)\end{array}$ & $\begin{array}{c}0.071^{* *} \\
(0.034)\end{array}$ \\
\hline Age 59 & $\begin{array}{c}0.030 \\
(0.029)\end{array}$ & $\begin{array}{l}0.053^{*} \\
(0.029)\end{array}$ & $\begin{array}{c}0.027 \\
(0.041)\end{array}$ & $\begin{array}{c}0.055 \\
(0.039)\end{array}$ \\
\hline Age 60 & $\begin{array}{c}0.023 \\
(0.027)\end{array}$ & $\begin{array}{l}0.049^{*} \\
(0.028)\end{array}$ & $\begin{array}{c}0.008 \\
(0.037)\end{array}$ & $\begin{array}{c}0.048 \\
(0.035)\end{array}$ \\
\hline Age 61 & $\begin{array}{c}0.021 \\
(0.030)\end{array}$ & $\begin{array}{c}0.030 \\
(0.032)\end{array}$ & $\begin{array}{l}-0.021 \\
(0.045)\end{array}$ & $\begin{array}{c}0.019 \\
(0.045)\end{array}$ \\
\hline Age 62 & $\begin{array}{c}0.012 \\
(0.032)\end{array}$ & $\begin{array}{c}0.037 \\
(0.031)\end{array}$ & $\begin{array}{c}0.004 \\
(0.044)\end{array}$ & $\begin{array}{c}0.051 \\
(0.040)\end{array}$ \\
\hline Age 63 & $\begin{array}{c}0.050 * \\
(0.030)\end{array}$ & $\begin{array}{c}0.071^{* *} \\
(0.031)\end{array}$ & $\begin{array}{c}0.012 \\
(0.046)\end{array}$ & $\begin{array}{c}0.048 \\
(0.047)\end{array}$ \\
\hline Male*(Age 41 to 45 ) & $\begin{array}{l}-0.032 \\
(0.033)\end{array}$ & $\begin{array}{c}-0.059^{*} \\
(0.035)\end{array}$ & $\begin{array}{l}-0.040 \\
(0.039)\end{array}$ & $\begin{array}{c}-0.083^{* *} \\
(0.041)\end{array}$ \\
\hline Male*(Age 46 to 50$)$ & $\begin{array}{l}-0.009 \\
(0.026)\end{array}$ & $\begin{array}{l}-0.016 \\
(0.026)\end{array}$ & $\begin{array}{l}-0.001 \\
(0.034)\end{array}$ & $\begin{array}{l}-0.016 \\
(0.033)\end{array}$ \\
\hline Male*(Age 51 to 55 ) & $\begin{array}{l}-0.007 \\
(0.028)\end{array}$ & $\begin{array}{l}-0.023 \\
(0.029)\end{array}$ & $\begin{array}{c}0.004 \\
(0.034)\end{array}$ & $\begin{array}{l}-0.017 \\
(0.033)\end{array}$ \\
\hline Male*(Age 56) & $\begin{array}{l}-0.009 \\
(0.032)\end{array}$ & $\begin{array}{l}-0.036 \\
(0.032)\end{array}$ & $\begin{array}{c}0.026 \\
(0.041)\end{array}$ & $\begin{array}{l}-0.009 \\
(0.040)\end{array}$ \\
\hline Male*(Age 57) & $\begin{array}{c}0.003 \\
(0.033)\end{array}$ & $\begin{array}{l}-0.005 \\
(0.035)\end{array}$ & $\begin{array}{c}0.026 \\
(0.048)\end{array}$ & $\begin{array}{c}0.006 \\
(0.047)\end{array}$ \\
\hline Male*(Age 58) & $\begin{array}{l}-0.024 \\
(0.030)\end{array}$ & $\begin{array}{l}-0.044 \\
(0.032)\end{array}$ & $\begin{array}{c}0.022 \\
(0.037)\end{array}$ & $\begin{array}{l}-0.031 \\
(0.037)\end{array}$ \\
\hline Male*(Age 59) & $\begin{array}{l}-0.027 \\
(0.033)\end{array}$ & $\begin{array}{l}-0.046 \\
(0.033)\end{array}$ & $\begin{array}{l}-0.031 \\
(0.045)\end{array}$ & $\begin{array}{l}-0.056 \\
(0.043)\end{array}$ \\
\hline Male*(Age 60) & $\begin{array}{l}-0.019 \\
(0.032)\end{array}$ & $\begin{array}{l}-0.031 \\
(0.033)\end{array}$ & $\begin{array}{l}-0.007 \\
(0.042)\end{array}$ & $\begin{array}{l}-0.028 \\
(0.039)\end{array}$ \\
\hline Male*(Age 61) & $\begin{array}{c}0.016 \\
(0.034)\end{array}$ & $\begin{array}{c}0.016 \\
(0.036)\end{array}$ & $\begin{array}{c}0.065 \\
(0.050)\end{array}$ & $\begin{array}{c}0.030 \\
(0.050)\end{array}$ \\
\hline Male*(Age 62) & $\begin{array}{l}-0.022 \\
(0.037)\end{array}$ & $\begin{array}{l}-0.053 \\
(0.037)\end{array}$ & $\begin{array}{l}-0.005 \\
(0.052)\end{array}$ & $\begin{array}{l}-0.070 \\
(0.047)\end{array}$ \\
\hline Male*(Age 63) & $\begin{array}{l}-0.036 \\
(0.035)\end{array}$ & $\begin{array}{l}-0.042 \\
(0.038)\end{array}$ & $\begin{array}{c}0.010 \\
(0.049)\end{array}$ & $\begin{array}{l}-0.022 \\
(0.052)\end{array}$ \\
\hline Male & $\begin{array}{c}0.013 \\
(0.023)\end{array}$ & $\begin{array}{c}0.021 \\
(0.024)\end{array}$ & $\begin{array}{c}0.011 \\
(0.029)\end{array}$ & $\begin{array}{c}0.032 \\
(0.027)\end{array}$ \\
\hline ICD9-410.0 & $\begin{array}{c}0.011 \\
(0.015)\end{array}$ & $\begin{array}{c}0.011 \\
(0.015)\end{array}$ & $\begin{array}{c}0.019 \\
(0.019)\end{array}$ & $\begin{array}{c}0.022 \\
(0.020)\end{array}$ \\
\hline ICD9-410.1 & $\begin{array}{l}0.019^{*} \\
(0.011)\end{array}$ & $\begin{array}{c}0.022^{* *} \\
(0.011)\end{array}$ & $\begin{array}{c}0.028^{* *} \\
(0.014)\end{array}$ & $\begin{array}{c}0.037^{* * *} \\
(0.014)\end{array}$ \\
\hline ICD9-410.2 & $\begin{array}{c}0.003 \\
(0.013)\end{array}$ & $\begin{array}{c}0.005 \\
(0.014)\end{array}$ & $\begin{array}{c}0.014 \\
(0.017)\end{array}$ & $\begin{array}{c}0.024 \\
(0.017)\end{array}$ \\
\hline ICD9-410.3 & $\begin{array}{l}0.033^{*} \\
(0.018)\end{array}$ & $\begin{array}{l}0.033^{*} \\
(0.019)\end{array}$ & $\begin{array}{c}0.048^{* *} \\
(0.022)\end{array}$ & $\begin{array}{c}0.057^{* *} \\
(0.023)\end{array}$ \\
\hline ICD9-410.4 & $\begin{array}{c}0.010 \\
(0.010)\end{array}$ & $\begin{array}{c}0.009 \\
(0.010)\end{array}$ & $\begin{array}{c}0.021 \\
(0.013)\end{array}$ & $\begin{array}{l}0.023^{*} \\
(0.013)\end{array}$ \\
\hline ICD9-410.5 & $\begin{array}{c}0.018 \\
(0.016)\end{array}$ & $\begin{array}{c}0.007 \\
(0.017)\end{array}$ & $\begin{array}{c}0.023 \\
(0.023)\end{array}$ & $\begin{array}{c}0.012 \\
(0.024)\end{array}$ \\
\hline ICD9-410.6 & $\begin{array}{c}0.018 \\
(0.037)\end{array}$ & $\begin{array}{c}0.001 \\
(0.039)\end{array}$ & $\begin{array}{c}0.101^{* *} \\
(0.045)\end{array}$ & $\begin{array}{l}0.087^{*} \\
(0.046)\end{array}$ \\
\hline
\end{tabular}




\begin{tabular}{|c|c|c|c|c|}
\hline ICD9-410.7 & $\begin{array}{c}0.005 \\
(0.009)\end{array}$ & $\begin{array}{c}0.004 \\
(0.009)\end{array}$ & $\begin{array}{c}0.018 \\
(0.013)\end{array}$ & $\begin{array}{l}0.021^{*} \\
(0.013)\end{array}$ \\
\hline ICD9-410.8 & $\begin{array}{c}0.036 \\
(0.022)\end{array}$ & $\begin{array}{c}0.040 \\
(0.025)\end{array}$ & $\begin{array}{c}0.045 \\
(0.033)\end{array}$ & $\begin{array}{c}0.033 \\
(0.037)\end{array}$ \\
\hline Charlson & $\begin{array}{c}0.003 \\
(0.007)\end{array}$ & $\begin{array}{c}0.001 \\
(0.007)\end{array}$ & $\begin{array}{c}0.042^{* * *} \\
(0.012)\end{array}$ & $\begin{array}{c}0.030^{* *} \\
(0.013)\end{array}$ \\
\hline Charlson $^{2}$ & $\begin{array}{c}0.001 \\
(0.003)\end{array}$ & $\begin{array}{c}0.001 \\
(0.003)\end{array}$ & $\begin{array}{c}-0.017^{* * *} \\
(0.006)\end{array}$ & $\begin{array}{l}-0.012^{*} \\
(0.006)\end{array}$ \\
\hline Charlson $^{3}$ & $\begin{array}{l}-0.000 \\
(0.000)\end{array}$ & $\begin{array}{l}-0.000 \\
(0.000)\end{array}$ & $\begin{array}{l}0.001 * * \\
(0.001)\end{array}$ & $\begin{array}{c}0.001 \\
(0.001)\end{array}$ \\
\hline Employer & $\begin{array}{c}-0.144^{* * *} \\
(0.012)\end{array}$ & $\begin{array}{c}-0.130^{* * *} \\
(0.014)\end{array}$ & $\begin{array}{c}-0.137^{* * *} \\
(0.014)\end{array}$ & $\begin{array}{c}-0.122^{* * *} \\
(0.015)\end{array}$ \\
\hline Prev. Adm. Hosp. & $\begin{array}{c}0.043^{* * *} \\
(0.016)\end{array}$ & $\begin{array}{c}0.045^{* * *} * \\
(0.017)\end{array}$ & $\begin{array}{c}0.018 \\
(0.030)\end{array}$ & $\begin{array}{c}0.014 \\
(0.033)\end{array}$ \\
\hline Univ. Hosp. per Capita & $\begin{array}{c}1158.919 \\
(1225.100)\end{array}$ & $\begin{array}{c}1459.208 \\
(1294.546)\end{array}$ & $\begin{array}{c}1498.494 \\
(1380.010)\end{array}$ & $\begin{array}{c}2293.042 \\
(1419.465)\end{array}$ \\
\hline Ins. Concentration & $\begin{array}{l}-0.018 \\
(0.020)\end{array}$ & $\begin{array}{l}-0.027 \\
(0.023)\end{array}$ & $\begin{array}{c}-0.048^{* *} \\
(0.022)\end{array}$ & $\begin{array}{l}-0.047^{*} \\
(0.025)\end{array}$ \\
\hline HMO & $\begin{array}{c}-0.081^{* * *} \\
(0.018)\end{array}$ & $\begin{array}{c}-0.073^{* * *} \\
(0.020)\end{array}$ & $\begin{array}{c}-0.079 * * * \\
(0.022)\end{array}$ & $\begin{array}{c}-0.074^{* * *} \\
(0.023)\end{array}$ \\
\hline $\mathrm{PPO}$ & $\begin{array}{c}-0.052^{* * *} \\
(0.012)\end{array}$ & $\begin{array}{c}-0.048^{* * *} \\
(0.013)\end{array}$ & $\begin{array}{c}-0.056^{* * *} \\
(0.016)\end{array}$ & $\begin{array}{c}-0.049 * * * \\
(0.017)\end{array}$ \\
\hline POS & $\begin{array}{c}-0.058^{* * *} \\
(0.016)\end{array}$ & $\begin{array}{c}-0.055^{* * *} \\
(0.016)\end{array}$ & $\begin{array}{c}-0.058^{* * *} \\
(0.020)\end{array}$ & $\begin{array}{c}-0.050^{* *} \\
(0.021)\end{array}$ \\
\hline CDHP & $\begin{array}{c}0.008 \\
(0.025)\end{array}$ & $\begin{array}{c}0.006 \\
(0.027)\end{array}$ & $\begin{array}{l}-0.023 \\
(0.029)\end{array}$ & $\begin{array}{l}-0.031 \\
(0.031)\end{array}$ \\
\hline HDHP & $\begin{array}{l}-0.072 \\
(0.051)\end{array}$ & $\begin{array}{l}-0.068 \\
(0.051)\end{array}$ & $\begin{array}{l}-0.118^{*} \\
(0.069)\end{array}$ & $\begin{array}{l}-0.109 \\
(0.070)\end{array}$ \\
\hline Hosp. per Capita & $\begin{array}{c}2384.378^{* *} \\
(1179.117)\end{array}$ & $\begin{array}{c}2711.032^{* *} \\
(1232.662)\end{array}$ & $\begin{array}{l}2121.676^{*} \\
(1198.483)\end{array}$ & $\begin{array}{c}2895.255^{* *} \\
(1282.412)\end{array}$ \\
\hline Cardiologists per Firm & $\begin{array}{c}0.000 \\
(0.002)\end{array}$ & $\begin{array}{l}-0.001 \\
(0.002)\end{array}$ & $\begin{array}{c}0.001 \\
(0.002)\end{array}$ & $\begin{array}{l}-0.001 \\
(0.002)\end{array}$ \\
\hline Cardiologists per Capita & $\begin{array}{c}237.932 \\
(182.496)\end{array}$ & $\begin{array}{c}191.450 \\
(190.182)\end{array}$ & $\begin{array}{c}313.517 \\
(206.697)\end{array}$ & $\begin{array}{c}223.096 \\
(212.099)\end{array}$ \\
\hline Persons per Sq. Mile & $\begin{array}{c}0.000 * * \\
(0.000)\end{array}$ & $\begin{array}{l}0.000^{*} \\
(0.000)\end{array}$ & $\begin{array}{c}0.000^{* *} \\
(0.000)\end{array}$ & $\begin{array}{l}0.000^{* *} \\
(0.000)\end{array}$ \\
\hline Log Med. Inc. & $\begin{array}{l}0.154^{* *} \\
(0.067)\end{array}$ & $\begin{array}{c}0.185^{* * *} * \\
(0.070)\end{array}$ & $\begin{array}{c}0.143^{* *} \\
(0.070)\end{array}$ & $\begin{array}{c}0.195 * * * \\
(0.074)\end{array}$ \\
\hline Log Hosp. Costs per Emp & $\begin{array}{c}0.029 * \\
(0.016)\end{array}$ & $\begin{array}{l}0.030 * \\
(0.016)\end{array}$ & $\begin{array}{c}0.019 \\
(0.018)\end{array}$ & $\begin{array}{c}0.025 \\
(0.018)\end{array}$ \\
\hline Log Med. Rent & $\begin{array}{l}-0.155 \\
(0.098)\end{array}$ & $\begin{array}{l}-0.153 \\
(0.100)\end{array}$ & $\begin{array}{l}-0.143 \\
(0.105)\end{array}$ & $\begin{array}{l}-0.147 \\
(0.107)\end{array}$ \\
\hline Log Med. House Val. & $\begin{array}{l}-0.024 \\
(0.052)\end{array}$ & $\begin{array}{l}-0.035 \\
(0.054)\end{array}$ & $\begin{array}{l}-0.037 \\
(0.060)\end{array}$ & $\begin{array}{l}-0.046 \\
(0.062)\end{array}$ \\
\hline Frac. Heavy Smokers & $\begin{array}{c}0.244 \\
(0.199)\end{array}$ & $\begin{array}{c}0.140 \\
(0.198)\end{array}$ & $\begin{array}{c}0.272 \\
(0.212)\end{array}$ & $\begin{array}{c}0.185 \\
(0.207)\end{array}$ \\
\hline Frac. Obese & $\begin{array}{c}0.204 \\
(0.164)\end{array}$ & $\begin{array}{c}0.198 \\
(0.175)\end{array}$ & $\begin{array}{c}0.220 \\
(0.193)\end{array}$ & $\begin{array}{c}0.161 \\
(0.207)\end{array}$ \\
\hline Treated Prevalence (non card) & $\begin{array}{l}-0.038 \\
(0.103)\end{array}$ & $\begin{array}{c}0.004 \\
(0.107)\end{array}$ & $\begin{array}{l}-0.065 \\
(0.121)\end{array}$ & $\begin{array}{l}-0.037 \\
(0.123)\end{array}$ \\
\hline Serv. Util. Index (non card) & $\begin{array}{c}0.586 * * * \\
(0.129)\end{array}$ & $\begin{array}{c}0.621^{* * *} \\
(0.130)\end{array}$ & $\begin{array}{c}0.699 * * * \\
(0.137)\end{array}$ & $\begin{array}{c}0.738^{* * *} \\
(0.137)\end{array}$ \\
\hline Observations & 11846 & 9836 & 6862 & 5739 \\
\hline
\end{tabular}


Table A2: Log RVUs, Log Procedures, Log RVUs per Procedure

\begin{tabular}{|c|c|c|c|c|c|c|c|c|c|c|c|c|}
\hline $\begin{array}{l}\text { Estimation } \\
\text { Sample }\end{array}$ & Log RVUs & Log RVUs & $\begin{array}{l}\text { OLS } \\
\text { Unexp. }\end{array}$ & $\begin{array}{c}\text { IV } \\
\text { Unexp. }\end{array}$ & Log Proc. & $\begin{array}{l}\text { IV } \\
\text { Full }\end{array}$ & $\begin{array}{l}\text { OLS } \\
\text { Unexp. }\end{array}$ & $\begin{array}{c}\text { IV } \\
\text { Unexp. }\end{array}$ & $\begin{array}{c}\text { Log RVUs } \\
\text { per Proc. } \\
\text { OLS } \\
\text { Full }\end{array}$ & $\begin{array}{c}\text { Log RVUs } \\
\text { per Proc. } \\
\text { IV } \\
\text { Full }\end{array}$ & $\begin{array}{c}\text { Log RVUs } \\
\text { per Proc. } \\
\text { OLS } \\
\text { Unexp. }\end{array}$ & $\begin{array}{c}\text { Log RVUs } \\
\text { per Proc. } \\
\text { IV } \\
\text { Unexp. }\end{array}$ \\
\hline $\ln \left(F T H H I_{p h y s}\right)$ & $\begin{array}{c}0.056^{* * *} \\
(0.018)\end{array}$ & $\begin{array}{c}0.073^{* * *} \\
(0.020)\end{array}$ & $\begin{array}{c}0.054^{* * *} \\
(0.021)\end{array}$ & $\begin{array}{c}0.066^{* * *} \\
(0.023)\end{array}$ & $\begin{array}{c}0.015 \\
(0.011)\end{array}$ & $\begin{array}{l}0.020^{*} \\
(0.012)\end{array}$ & $\begin{array}{c}0.013 \\
(0.012)\end{array}$ & $\begin{array}{c}0.016 \\
(0.013)\end{array}$ & $\begin{array}{c}0.041^{* * *} \\
(0.015)\end{array}$ & $\begin{array}{c}0.053^{* * *} \\
(0.017)\end{array}$ & $\begin{array}{c}0.041^{* * *} \\
(0.016)\end{array}$ & $\begin{array}{c}0.050^{* * *} \\
(0.017)\end{array}$ \\
\hline Age 41 to 45 & $\begin{array}{c}0.111 \\
(0.088)\end{array}$ & $\begin{array}{c}0.118 \\
(0.102)\end{array}$ & $\begin{array}{c}0.093 \\
(0.118)\end{array}$ & $\begin{array}{c}0.046 \\
(0.137)\end{array}$ & $\begin{array}{c}0.027 \\
(0.058)\end{array}$ & $\begin{array}{c}0.047 \\
(0.067)\end{array}$ & $\begin{array}{c}0.022 \\
(0.074)\end{array}$ & $\begin{array}{c}0.026 \\
(0.084)\end{array}$ & $\begin{array}{l}0.084^{*} \\
(0.051)\end{array}$ & $\begin{array}{c}0.071 \\
(0.058)\end{array}$ & $\begin{array}{c}0.071 \\
(0.067)\end{array}$ & $\begin{array}{c}0.020 \\
(0.077)\end{array}$ \\
\hline Age 46 to 50 & $\begin{array}{c}0.187^{* *} \\
(0.079)\end{array}$ & $\begin{array}{c}0.205^{* *} \\
(0.093)\end{array}$ & $\begin{array}{l}0.210^{* *} \\
(0.098)\end{array}$ & $\begin{array}{l}0.237^{*} \\
(0.124)\end{array}$ & $\begin{array}{c}0.074 \\
(0.049)\end{array}$ & $\begin{array}{c}0.092 \\
(0.056)\end{array}$ & $\begin{array}{c}0.104 \\
(0.064)\end{array}$ & $\begin{array}{l}0.133^{*} \\
(0.075)\end{array}$ & $\begin{array}{l}0.113^{* *} \\
(0.048)\end{array}$ & $\begin{array}{c}0.114^{* *} \\
(0.056)\end{array}$ & $\begin{array}{l}0.106^{*} \\
(0.056)\end{array}$ & $\begin{array}{c}0.104 \\
(0.068)\end{array}$ \\
\hline Age 51 to 55 & $\begin{array}{c}0.210^{* * *} \\
(0.076)\end{array}$ & $\begin{array}{l}0.203^{* *} \\
(0.083)\end{array}$ & $\begin{array}{c}0.281 * * * \\
(0.093)\end{array}$ & $\begin{array}{l}0.245^{* *} \\
(0.103)\end{array}$ & $\begin{array}{l}0.108^{* *} \\
(0.047)\end{array}$ & $\begin{array}{l}0.113^{* *} \\
(0.051)\end{array}$ & $\begin{array}{c}0.155^{* * *} \\
(0.060)\end{array}$ & $\begin{array}{l}0.151^{* *} \\
(0.065)\end{array}$ & $\begin{array}{l}0.101 * * \\
(0.046)\end{array}$ & $\begin{array}{l}0.090^{*} \\
(0.051)\end{array}$ & $\begin{array}{c}0.126^{* *} \\
(0.055)\end{array}$ & $\begin{array}{c}0.094 \\
(0.059)\end{array}$ \\
\hline Age 56 & $\begin{array}{c}0.135 \\
(0.104)\end{array}$ & $\begin{array}{c}0.175 \\
(0.108)\end{array}$ & $\begin{array}{l}0.230^{*} \\
(0.138)\end{array}$ & $\begin{array}{c}0.206 \\
(0.149)\end{array}$ & $\begin{array}{c}0.054 \\
(0.062)\end{array}$ & $\begin{array}{c}0.083 \\
(0.065)\end{array}$ & $\begin{array}{c}0.094 \\
(0.080)\end{array}$ & $\begin{array}{c}0.095 \\
(0.089)\end{array}$ & $\begin{array}{c}0.081 \\
(0.061)\end{array}$ & $\begin{array}{c}0.092 \\
(0.063)\end{array}$ & $\begin{array}{l}0.136^{*} \\
(0.083)\end{array}$ & $\begin{array}{c}0.110 \\
(0.087)\end{array}$ \\
\hline Age 57 & $\begin{array}{c}0.204^{* *} \\
(0.103)\end{array}$ & $\begin{array}{l}0.192^{*} \\
(0.115)\end{array}$ & $\begin{array}{c}0.141 \\
(0.139)\end{array}$ & $\begin{array}{c}0.099 \\
(0.158)\end{array}$ & $\begin{array}{c}0.088 \\
(0.065)\end{array}$ & $\begin{array}{c}0.103 \\
(0.071)\end{array}$ & $\begin{array}{c}0.035 \\
(0.087)\end{array}$ & $\begin{array}{c}0.050 \\
(0.099)\end{array}$ & $\begin{array}{l}0.117^{*} \\
(0.060)\end{array}$ & $\begin{array}{c}0.089 \\
(0.067)\end{array}$ & $\begin{array}{c}0.107 \\
(0.082)\end{array}$ & $\begin{array}{c}0.049 \\
(0.090)\end{array}$ \\
\hline Age 58 & $\begin{array}{l}0.201 * * \\
(0.087)\end{array}$ & $\begin{array}{l}0.219 * * \\
(0.096)\end{array}$ & $\begin{array}{c}0.134 \\
(0.118)\end{array}$ & $\begin{array}{c}0.046 \\
(0.138)\end{array}$ & $\begin{array}{c}0.088 \\
(0.060)\end{array}$ & $\begin{array}{l}0.127^{* *} \\
(0.064)\end{array}$ & $\begin{array}{c}0.055 \\
(0.076)\end{array}$ & $\begin{array}{c}0.037 \\
(0.085)\end{array}$ & $\begin{array}{l}0.113^{* *} \\
(0.054)\end{array}$ & $\begin{array}{c}0.092 \\
(0.061)\end{array}$ & $\begin{array}{l}0.079 \\
(0.070)\end{array}$ & $\begin{array}{c}0.009 \\
(0.083)\end{array}$ \\
\hline Age 59 & $\begin{array}{c}0.149 \\
(0.106)\end{array}$ & $\begin{array}{c}0.132 \\
(0.113)\end{array}$ & $\begin{array}{c}0.174 \\
(0.144)\end{array}$ & $\begin{array}{c}0.128 \\
(0.159)\end{array}$ & $\begin{array}{c}0.083 \\
(0.067)\end{array}$ & $\begin{array}{c}0.093 \\
(0.071)\end{array}$ & $\begin{array}{c}0.095 \\
(0.090)\end{array}$ & $\begin{array}{c}0.109 \\
(0.100)\end{array}$ & $\begin{array}{c}0.067 \\
(0.060)\end{array}$ & $\begin{array}{c}0.038 \\
(0.064)\end{array}$ & $\begin{array}{c}0.078 \\
(0.082)\end{array}$ & $\begin{array}{c}0.018 \\
(0.088)\end{array}$ \\
\hline Age 60 & $\begin{array}{c}0.257^{* * *} \\
(0.088)\end{array}$ & $\begin{array}{l}0.236^{* *} \\
(0.099)\end{array}$ & $\begin{array}{l}0.205^{*} \\
(0.111)\end{array}$ & $\begin{array}{c}0.198 \\
(0.123)\end{array}$ & $\begin{array}{l}0.135 * * \\
(0.059)\end{array}$ & $\begin{array}{l}0.136 * * \\
(0.062)\end{array}$ & $\begin{array}{l}0.146^{*} \\
(0.076)\end{array}$ & $\begin{array}{l}0.157^{*} \\
(0.084)\end{array}$ & $\begin{array}{l}0.122^{* *} \\
(0.052)\end{array}$ & $\begin{array}{l}0.100^{*} \\
(0.058)\end{array}$ & $\begin{array}{c}0.059 \\
(0.064)\end{array}$ & $\begin{array}{c}0.041 \\
(0.070)\end{array}$ \\
\hline Age 61 & $\begin{array}{c}0.087 \\
(0.101)\end{array}$ & $\begin{array}{c}0.150 \\
(0.121)\end{array}$ & $\begin{array}{c}0.203 \\
(0.129)\end{array}$ & $\begin{array}{c}0.166 \\
(0.159)\end{array}$ & $\begin{array}{c}0.025 \\
(0.070)\end{array}$ & $\begin{array}{c}0.047 \\
(0.082)\end{array}$ & $\begin{array}{c}0.131 \\
(0.087)\end{array}$ & $\begin{array}{c}0.113 \\
(0.101)\end{array}$ & $\begin{array}{c}0.061 \\
(0.056)\end{array}$ & $\begin{array}{c}0.104 \\
(0.065)\end{array}$ & $\begin{array}{c}0.072 \\
(0.079)\end{array}$ & $\begin{array}{c}0.053 \\
(0.092)\end{array}$ \\
\hline Age 62 & $\begin{array}{c}0.258^{* * *} \\
(0.092)\end{array}$ & $\begin{array}{c}0.259^{* *} \\
(0.111)\end{array}$ & $\begin{array}{c}0.352^{* * *} \\
(0.116)\end{array}$ & $\begin{array}{l}0.267^{*} \\
(0.148)\end{array}$ & $\begin{array}{c}0.174^{* * *} \\
(0.054)\end{array}$ & $\begin{array}{c}0.190^{* * *} \\
(0.063)\end{array}$ & $\begin{array}{c}0.201 * * * \\
(0.077)\end{array}$ & $\begin{array}{l}0.212^{* *} \\
(0.094)\end{array}$ & $\begin{array}{c}0.084 \\
(0.064)\end{array}$ & $\begin{array}{c}0.068 \\
(0.074)\end{array}$ & $\begin{array}{l}0.151^{*} \\
(0.080)\end{array}$ & $\begin{array}{c}0.055 \\
(0.094)\end{array}$ \\
\hline Age 63 & $\begin{array}{c}0.342^{* * *} \\
(0.092)\end{array}$ & $\begin{array}{c}0.328^{* * *} \\
(0.101)\end{array}$ & $\begin{array}{c}0.372^{* * *} \\
(0.117)\end{array}$ & $\begin{array}{l}0.307^{* *} \\
(0.128)\end{array}$ & $\begin{array}{c}0.186^{* * *} \\
(0.056)\end{array}$ & $\begin{array}{c}0.197^{* * *} \\
(0.063)\end{array}$ & $\begin{array}{l}0.198^{* *} \\
(0.081)\end{array}$ & $\begin{array}{l}0.174^{*} \\
(0.090)\end{array}$ & $\begin{array}{c}0.156^{* * *} \\
(0.058)\end{array}$ & $\begin{array}{l}0.131^{* *} \\
(0.062)\end{array}$ & $\begin{array}{c}0.174^{* * *} \\
(0.075)\end{array}$ & $\begin{array}{l}0.133^{*} \\
(0.079)\end{array}$ \\
\hline Male*(Age 41 to 45 ) & $\begin{array}{c}0.050 \\
(0.093)\end{array}$ & $\begin{array}{c}0.025 \\
(0.108)\end{array}$ & $\begin{array}{c}0.094 \\
(0.126)\end{array}$ & $\begin{array}{c}0.132 \\
(0.145)\end{array}$ & $\begin{array}{c}0.009 \\
(0.062)\end{array}$ & $\begin{array}{l}-0.018 \\
(0.071)\end{array}$ & $\begin{array}{l}-0.007 \\
(0.080)\end{array}$ & $\begin{array}{l}-0.007 \\
(0.088)\end{array}$ & $\begin{array}{c}0.040 \\
(0.057)\end{array}$ & $\begin{array}{c}0.043 \\
(0.066)\end{array}$ & $\begin{array}{l}0.100 \\
(0.074)\end{array}$ & $\begin{array}{c}0.139 \\
(0.086)\end{array}$ \\
\hline Male*(Age 46 to 50 ) & $\begin{array}{l}-0.039 \\
(0.088)\end{array}$ & $\begin{array}{l}-0.072 \\
(0.099)\end{array}$ & $\begin{array}{l}-0.051 \\
(0.107)\end{array}$ & $\begin{array}{l}-0.094 \\
(0.128)\end{array}$ & $\begin{array}{l}-0.059 \\
(0.053)\end{array}$ & $\begin{array}{l}-0.078 \\
(0.060)\end{array}$ & $\begin{array}{l}-0.097 \\
(0.071)\end{array}$ & $\begin{array}{l}-0.129 \\
(0.080)\end{array}$ & $\begin{array}{c}0.021 \\
(0.057)\end{array}$ & $\begin{array}{c}0.006 \\
(0.062)\end{array}$ & $\begin{array}{c}0.046 \\
(0.064)\end{array}$ & $\begin{array}{c}0.034 \\
(0.074)\end{array}$ \\
\hline Male*(Age 51 to 55 ) & $\begin{array}{l}-0.027 \\
(0.084)\end{array}$ & $\begin{array}{l}-0.012 \\
(0.090)\end{array}$ & $\begin{array}{l}-0.085 \\
(0.105)\end{array}$ & $\begin{array}{l}-0.049 \\
(0.114)\end{array}$ & $\begin{array}{l}-0.059 \\
(0.053)\end{array}$ & $\begin{array}{l}-0.058 \\
(0.056)\end{array}$ & $\begin{array}{c}-0.116^{*} \\
(0.068)\end{array}$ & $\begin{array}{l}-0.101 \\
(0.073)\end{array}$ & $\begin{array}{c}0.032 \\
(0.053)\end{array}$ & $\begin{array}{c}0.046 \\
(0.056)\end{array}$ & $\begin{array}{c}0.031 \\
(0.064)\end{array}$ & $\begin{array}{c}0.052 \\
(0.068)\end{array}$ \\
\hline Male*(Age 56) & $\begin{array}{c}0.014 \\
(0.112)\end{array}$ & $\begin{array}{l}-0.034 \\
(0.117)\end{array}$ & $\begin{array}{l}-0.010 \\
(0.152)\end{array}$ & $\begin{array}{c}0.037 \\
(0.162)\end{array}$ & $\begin{array}{l}-0.020 \\
(0.067)\end{array}$ & $\begin{array}{l}-0.051 \\
(0.072)\end{array}$ & $\begin{array}{l}-0.057 \\
(0.090)\end{array}$ & $\begin{array}{c}-0.037 \\
(0.097)\end{array}$ & $\begin{array}{c}0.034 \\
(0.070)\end{array}$ & $\begin{array}{c}0.017 \\
(0.072)\end{array}$ & $\begin{array}{c}0.047 \\
(0.094)\end{array}$ & $\begin{array}{c}0.075 \\
(0.097)\end{array}$ \\
\hline Male*(Age 57) & $\begin{array}{l}0.057 \\
(0.114)\end{array}$ & $\begin{array}{c}0.037 \\
(0.124)\end{array}$ & $\begin{array}{l}0.096 \\
(0.148)\end{array}$ & $\begin{array}{c}0.120 \\
(0.166)\end{array}$ & $\begin{array}{c}0.007 \\
(0.074)\end{array}$ & $\begin{array}{l}-0.020 \\
(0.079)\end{array}$ & $\begin{array}{c}0.027 \\
(0.094)\end{array}$ & $\begin{array}{c}0.010 \\
(0.104)\end{array}$ & $\begin{array}{c}0.050 \\
(0.068)\end{array}$ & $\begin{array}{c}0.057 \\
(0.075)\end{array}$ & $\begin{array}{c}0.069 \\
(0.092)\end{array}$ & $\begin{array}{l}0.110 \\
(0.099)\end{array}$ \\
\hline Male*(Age 58) & $\begin{array}{c}0.007 \\
(0.100)\end{array}$ & $\begin{array}{l}-0.022 \\
(0.107)\end{array}$ & $\begin{array}{c}0.069 \\
(0.131)\end{array}$ & $\begin{array}{c}0.144 \\
(0.147)\end{array}$ & $\begin{array}{c}0.004 \\
(0.068)\end{array}$ & $\begin{array}{l}-0.039 \\
(0.071)\end{array}$ & $\begin{array}{c}0.027 \\
(0.084)\end{array}$ & $\begin{array}{c}0.045 \\
(0.092)\end{array}$ & $\begin{array}{c}0.003 \\
(0.061)\end{array}$ & $\begin{array}{c}0.017 \\
(0.067)\end{array}$ & $\begin{array}{c}0.042 \\
(0.079)\end{array}$ & $\begin{array}{c}0.099 \\
(0.090)\end{array}$ \\
\hline Male*(Age 59) & $\begin{array}{c}-0.004 \\
(0.117)\end{array}$ & $\begin{array}{l}-0.021 \\
(0.124)\end{array}$ & $\begin{array}{c}-0.061 \\
(0.160)\end{array}$ & $\begin{array}{l}-0.068 \\
(0.175)\end{array}$ & $\begin{array}{c}-0.053 \\
(0.075)\end{array}$ & $\begin{array}{c}-0.091 \\
(0.079)\end{array}$ & $\begin{array}{c}-0.114 \\
(0.106)\end{array}$ & $\begin{array}{l}-0.161 \\
(0.115)\end{array}$ & $\begin{array}{c}0.049 \\
(0.068)\end{array}$ & $\begin{array}{c}0.070 \\
(0.071)\end{array}$ & $\begin{array}{c}0.053 \\
(0.089)\end{array}$ & $\begin{array}{c}0.093 \\
(0.094)\end{array}$ \\
\hline Male*(Age 60) & $\begin{array}{l}-0.037 \\
(0.099)\end{array}$ & $\begin{array}{l}-0.014 \\
(0.105)\end{array}$ & $\begin{array}{c}0.041 \\
(0.123)\end{array}$ & $\begin{array}{c}0.057 \\
(0.131)\end{array}$ & $\begin{array}{l}-0.071 \\
(0.065)\end{array}$ & $\begin{array}{l}-0.068 \\
(0.066)\end{array}$ & $\begin{array}{l}-0.094 \\
(0.084)\end{array}$ & $\begin{array}{l}-0.086 \\
(0.092)\end{array}$ & $\begin{array}{c}0.033 \\
(0.058)\end{array}$ & $\begin{array}{c}0.054 \\
(0.065)\end{array}$ & $\begin{array}{l}0.135^{*} \\
(0.073)\end{array}$ & $\begin{array}{l}0.142^{*} \\
(0.078)\end{array}$ \\
\hline Male*(Age 61) & $\begin{array}{c}0.097 \\
(0.114)\end{array}$ & $\begin{array}{c}0.053 \\
(0.136)\end{array}$ & $\begin{array}{l}-0.025 \\
(0.153)\end{array}$ & $\begin{array}{c}0.013 \\
(0.190)\end{array}$ & $\begin{array}{c}0.024 \\
(0.078)\end{array}$ & $\begin{array}{c}0.016 \\
(0.090)\end{array}$ & $\begin{array}{l}-0.110 \\
(0.100)\end{array}$ & $\begin{array}{l}-0.090 \\
(0.118)\end{array}$ & $\begin{array}{c}0.073 \\
(0.066)\end{array}$ & $\begin{array}{c}0.037 \\
(0.077)\end{array}$ & $\begin{array}{c}0.085 \\
(0.093)\end{array}$ & $\begin{array}{c}0.103 \\
(0.109)\end{array}$ \\
\hline Male*(Age 62) & $\begin{array}{l}-0.072 \\
(0.106)\end{array}$ & $\begin{array}{l}-0.079 \\
(0.125)\end{array}$ & $\begin{array}{l}-0.225 \\
(0.139)\end{array}$ & $\begin{array}{l}-0.134 \\
(0.171)\end{array}$ & $\begin{array}{c}-0.114^{*} \\
(0.062)\end{array}$ & $\begin{array}{l}-0.134^{*} \\
(0.072)\end{array}$ & $\begin{array}{c}-0.200^{* *} \\
(0.095)\end{array}$ & $\begin{array}{l}-0.204^{*} \\
(0.113)\end{array}$ & $\begin{array}{c}0.042 \\
(0.074)\end{array}$ & $\begin{array}{c}0.054 \\
(0.084)\end{array}$ & $\begin{array}{l}-0.024 \\
(0.093)\end{array}$ & $\begin{array}{c}0.069 \\
(0.107)\end{array}$ \\
\hline
\end{tabular}




\begin{tabular}{|c|c|c|c|c|c|c|c|c|c|c|c|c|}
\hline Male*(Age 63) & $\begin{array}{l}-0.114 \\
(0.103)\end{array}$ & $\begin{array}{l}-0.133 \\
(0.117)\end{array}$ & $\begin{array}{l}-0.202 \\
(0.135)\end{array}$ & $\begin{array}{l}-0.156 \\
(0.150)\end{array}$ & $\begin{array}{l}-0.065 \\
(0.065)\end{array}$ & $\begin{array}{l}-0.100 \\
(0.074)\end{array}$ & $\begin{array}{l}-0.146 \\
(0.093)\end{array}$ & $\begin{array}{l}-0.134 \\
(0.105)\end{array}$ & $\begin{array}{l}-0.049 \\
(0.068)\end{array}$ & $\begin{array}{l}-0.033 \\
(0.073)\end{array}$ & $\begin{array}{l}-0.056 \\
(0.088)\end{array}$ & $\begin{array}{l}-0.022 \\
(0.091)\end{array}$ \\
\hline Male & $\begin{array}{l}0.193^{* *} \\
(0.079)\end{array}$ & $\begin{array}{l}0.207^{* *} \\
(0.086)\end{array}$ & $\begin{array}{c}0.193^{* *} \\
(0.092)\end{array}$ & $\begin{array}{l}0.181^{*} \\
(0.104)\end{array}$ & $\begin{array}{l}0.098^{* *} \\
(0.049)\end{array}$ & $\begin{array}{l}0.117^{* *} \\
(0.054)\end{array}$ & $\begin{array}{l}0.128^{* *} \\
(0.062)\end{array}$ & $\begin{array}{l}0.137^{* *} \\
(0.067)\end{array}$ & $\begin{array}{c}0.095^{* *} \\
(0.048)\end{array}$ & $\begin{array}{l}0.090^{*} \\
(0.053)\end{array}$ & $\begin{array}{c}0.065 \\
(0.053)\end{array}$ & $\begin{array}{c}0.044 \\
(0.058)\end{array}$ \\
\hline ICD9-410.0 & $\begin{array}{c}0.486 * * * \\
(0.049)\end{array}$ & $\begin{array}{c}0.454^{* * *} \\
(0.053)\end{array}$ & $\begin{array}{c}0.483 * * * \\
(0.067)\end{array}$ & $\begin{array}{c}0.441^{* * *} \\
(0.074)\end{array}$ & $\begin{array}{c}0.305^{* * *} \\
(0.033)\end{array}$ & $\begin{array}{c}0.296 * * * \\
(0.034)\end{array}$ & $\begin{array}{c}0.307 * * * \\
(0.041)\end{array}$ & $\begin{array}{c}0.279 * * * \\
(0.043)\end{array}$ & $\begin{array}{c}0.181 * * * \\
(0.027)\end{array}$ & $\begin{array}{c}0.158^{* * *} \\
(0.031)\end{array}$ & $\begin{array}{c}0.176^{* * *} \\
(0.040)\end{array}$ & $\begin{array}{c}0.162^{* * * *} \\
(0.045)\end{array}$ \\
\hline ICD9-410.1 & $\begin{array}{c}0.573^{* * *} \\
(0.036)\end{array}$ & $\begin{array}{c}0.547^{* * *} \\
(0.037)\end{array}$ & $\begin{array}{c}0.587^{* * *} \\
(0.041)\end{array}$ & $\begin{array}{c}0.558^{* * *} \\
(0.043)\end{array}$ & $\begin{array}{c}0.323 * * * \\
(0.022)\end{array}$ & $\begin{array}{c}0.315^{* * *} \\
(0.023)\end{array}$ & $\begin{array}{c}0.337^{* * *} \\
(0.025)\end{array}$ & $\begin{array}{c}0.321^{* * *} \\
(0.028)\end{array}$ & $\begin{array}{c}0.250^{* * *} \\
(0.022)\end{array}$ & $\begin{array}{c}0.232^{* * *} \\
(0.023)\end{array}$ & $\begin{array}{c}0.250^{* * * *} \\
(0.026)\end{array}$ & $\begin{array}{c}0.237^{* * *} \\
(0.026)\end{array}$ \\
\hline ICD9-410.2 & $\begin{array}{c}0.520^{* * *} \\
(0.048)\end{array}$ & $\begin{array}{c}0.509^{* * *} \\
(0.050)\end{array}$ & $\begin{array}{c}0.510^{* * *} \\
(0.057)\end{array}$ & $\begin{array}{c}0.501 * * * \\
(0.062)\end{array}$ & $\begin{array}{c}0.255 * * * \\
(0.029)\end{array}$ & $\begin{array}{c}0.246^{* * *} \\
(0.030)\end{array}$ & $\begin{array}{c}0.249^{* * *} \\
(0.036)\end{array}$ & $\begin{array}{c}0.243^{* * *} \\
(0.039)\end{array}$ & $\begin{array}{c}0.265^{* * *} \\
(0.030)\end{array}$ & $\begin{array}{c}0.263^{* * *} \\
(0.031)\end{array}$ & $\begin{array}{c}0.261^{* * *} \\
(0.037)\end{array}$ & $\begin{array}{c}0.259^{* * *} \\
(0.039)\end{array}$ \\
\hline ICD9-410.3 & $\begin{array}{c}0.556^{* * *} \\
(0.055)\end{array}$ & $\begin{array}{c}0.547^{* * *} \\
(0.060)\end{array}$ & $\begin{array}{c}0.505^{* * *} \\
(0.067)\end{array}$ & $\begin{array}{c}0.488^{* * *} \\
(0.072)\end{array}$ & $\begin{array}{c}0.315^{* * *} \\
(0.032)\end{array}$ & $\begin{array}{c}0.322 * * * \\
(0.034)\end{array}$ & $\begin{array}{c}0.301 * * * \\
(0.040)\end{array}$ & $\begin{array}{c}0.285^{* * *} \\
(0.042)\end{array}$ & $\begin{array}{c}0.241^{* * *} \\
(0.035)\end{array}$ & $\begin{array}{c}0.224^{* * *} \\
(0.038)\end{array}$ & $\begin{array}{c}0.204^{* * *} \\
(0.042)\end{array}$ & $\begin{array}{c}0.202^{* * * *} \\
(0.046)\end{array}$ \\
\hline ICD9-410.4 & $\begin{array}{c}0.582^{* * *} \\
(0.035)\end{array}$ & $\begin{array}{c}0.553^{* * *} \\
(0.035)\end{array}$ & $\begin{array}{c}0.604^{* * *} \\
(0.040)\end{array}$ & $\begin{array}{c}0.572^{* * *} \\
(0.041)\end{array}$ & $\begin{array}{c}0.250^{* * *} \\
(0.023)\end{array}$ & $\begin{array}{c}0.244^{* * *} \\
(0.022)\end{array}$ & $\begin{array}{c}0.262^{* * *} \\
(0.024)\end{array}$ & $\begin{array}{c}0.255^{* * *} \\
(0.026)\end{array}$ & $\begin{array}{c}0.332^{* * *} \\
(0.019)\end{array}$ & $\begin{array}{c}0.309^{* * *} \\
(0.021)\end{array}$ & $\begin{array}{c}0.342^{* * *} \\
(0.025)\end{array}$ & $\begin{array}{c}0.317^{* * *} \\
(0.026)\end{array}$ \\
\hline ICD9-410.5 & $\begin{array}{c}0.455 * * * \\
(0.062)\end{array}$ & $\begin{array}{c}0.443^{* * *} \\
(0.067)\end{array}$ & $\begin{array}{c}0.516^{* * * *} \\
(0.074)\end{array}$ & $\begin{array}{c}0.501 * * * \\
(0.078)\end{array}$ & $\begin{array}{c}0.231^{* * *} \\
(0.039)\end{array}$ & $\begin{array}{c}0.231^{* * *} \\
(0.042)\end{array}$ & $\begin{array}{c}0.245^{* * *} \\
(0.047)\end{array}$ & $\begin{array}{c}0.217^{* * *} \\
(0.051)\end{array}$ & $\begin{array}{c}0.224^{* * *} \\
(0.040)\end{array}$ & $\begin{array}{c}0.212^{* * *} \\
(0.042)\end{array}$ & $\begin{array}{c}0.270^{* * * *} \\
(0.046)\end{array}$ & $\begin{array}{c}0.284^{* * *} \\
(0.045)\end{array}$ \\
\hline ICD9-410.6 & $\begin{array}{c}0.430^{* * *} \\
(0.119)\end{array}$ & $\begin{array}{c}0.383^{* * *} \\
(0.125)\end{array}$ & $\begin{array}{c}0.434^{* * *} \\
(0.133)\end{array}$ & $\begin{array}{c}0.376^{* * *} \\
(0.145)\end{array}$ & $\begin{array}{c}0.234^{* * *} \\
(0.077)\end{array}$ & $\begin{array}{c}0.211^{* * *} \\
(0.080)\end{array}$ & $\begin{array}{l}0.218^{* *} \\
(0.090)\end{array}$ & $\begin{array}{l}0.179^{*} \\
(0.097)\end{array}$ & $\begin{array}{c}0.196^{* * *} \\
(0.069)\end{array}$ & $\begin{array}{c}0.172^{* *} \\
(0.072)\end{array}$ & $\begin{array}{c}0.216^{* * *} \\
(0.078)\end{array}$ & $\begin{array}{c}0.197^{* *} \\
(0.083)\end{array}$ \\
\hline ICD9-410.7 & $\begin{array}{c}0.349 * * * \\
(0.032)\end{array}$ & $\begin{array}{c}0.323 * * * \\
(0.033)\end{array}$ & $\begin{array}{c}0.349 * * * \\
(0.036)\end{array}$ & $\begin{array}{c}0.324^{* * *} \\
(0.038)\end{array}$ & $\begin{array}{c}0.168 * * * \\
(0.019)\end{array}$ & $\begin{array}{c}0.158^{* * *} \\
(0.020)\end{array}$ & $\begin{array}{c}0.170^{* * *} \\
(0.022)\end{array}$ & $\begin{array}{c}0.156^{* * *} \\
(0.024)\end{array}$ & $\begin{array}{c}0.181^{* * *} \\
(0.019)\end{array}$ & $\begin{array}{c}0.164^{* * *} \\
(0.020)\end{array}$ & $\begin{array}{c}0.178^{* * *} \\
(0.023)\end{array}$ & $\begin{array}{c}0.168^{* * * *} \\
(0.024)\end{array}$ \\
\hline ICD9-410.8 & $\begin{array}{c}0.078 \\
(0.081)\end{array}$ & $\begin{array}{c}0.072 \\
(0.093)\end{array}$ & $\begin{array}{c}0.134 \\
(0.104)\end{array}$ & $\begin{array}{c}0.051 \\
(0.122)\end{array}$ & $\begin{array}{c}0.047 \\
(0.048)\end{array}$ & $\begin{array}{c}0.051 \\
(0.053)\end{array}$ & $\begin{array}{c}0.024 \\
(0.061)\end{array}$ & $\begin{array}{c}0.014 \\
(0.066)\end{array}$ & $\begin{array}{c}0.031 \\
(0.047)\end{array}$ & $\begin{array}{c}0.021 \\
(0.056)\end{array}$ & $\begin{array}{l}0.109^{*} \\
(0.066)\end{array}$ & $\begin{array}{c}0.038 \\
(0.077)\end{array}$ \\
\hline Charlson & $\begin{array}{c}-0.048^{* *} \\
(0.021)\end{array}$ & $\begin{array}{c}-0.049^{* *} \\
(0.023)\end{array}$ & $\begin{array}{c}-0.079^{*} \\
(0.046)\end{array}$ & $\begin{array}{l}-0.090^{*} \\
(0.048)\end{array}$ & $\begin{array}{l}-0.004 \\
(0.016)\end{array}$ & $\begin{array}{c}0.000 \\
(0.017)\end{array}$ & $\begin{array}{l}-0.036 \\
(0.031)\end{array}$ & $\begin{array}{l}-0.038 \\
(0.031)\end{array}$ & $\begin{array}{c}-0.044^{* * *} \\
(0.013)\end{array}$ & $\begin{array}{c}-0.049^{* * *} \\
(0.013)\end{array}$ & $\begin{array}{c}-0.043^{*} \\
(0.025)\end{array}$ & $\begin{array}{c}-0.051^{*} \\
(0.028)\end{array}$ \\
\hline Charlson $^{2}$ & $\begin{array}{c}0.002 \\
(0.009)\end{array}$ & $\begin{array}{l}0.004 \\
(0.009)\end{array}$ & $\begin{array}{l}0.044^{*} \\
(0.026)\end{array}$ & $\begin{array}{l}0.051^{* *} \\
(0.025)\end{array}$ & $\begin{array}{l}-0.000 \\
(0.007)\end{array}$ & $\begin{array}{l}-0.002 \\
(0.008)\end{array}$ & $\begin{array}{c}0.035^{* *} \\
(0.017)\end{array}$ & $\begin{array}{l}0.037^{* *} \\
(0.016)\end{array}$ & $\begin{array}{c}0.002 \\
(0.005)\end{array}$ & $\begin{array}{c}0.006 \\
(0.006)\end{array}$ & $\begin{array}{c}0.009 \\
(0.014)\end{array}$ & $\begin{array}{c}0.013 \\
(0.016)\end{array}$ \\
\hline Charlson $^{3}$ & $\begin{array}{l}-0.000 \\
(0.001)\end{array}$ & $\begin{array}{l}-0.000 \\
(0.001)\end{array}$ & $\begin{array}{c}-0.005^{*} \\
(0.003)\end{array}$ & $\begin{array}{c}-0.005^{* *} \\
(0.003)\end{array}$ & $\begin{array}{l}-0.000 \\
(0.001)\end{array}$ & $\begin{array}{c}0.000 \\
(0.001)\end{array}$ & $\begin{array}{c}-0.004^{* *} \\
(0.002)\end{array}$ & $\begin{array}{c}-0.004^{* * *} \\
(0.002)\end{array}$ & $\begin{array}{l}-0.000 \\
(0.000)\end{array}$ & $\begin{array}{l}-0.000 \\
(0.000)\end{array}$ & $\begin{array}{l}-0.001 \\
(0.001)\end{array}$ & $\begin{array}{l}-0.001 \\
(0.002)\end{array}$ \\
\hline Employer & $\begin{array}{c}0.159^{* * *} \\
(0.028)\end{array}$ & $\begin{array}{c}0.171^{* * *} \\
(0.030)\end{array}$ & $\begin{array}{c}0.184^{* * *} \\
(0.037)\end{array}$ & $\begin{array}{c}0.203^{* * *} \\
(0.038)\end{array}$ & $\begin{array}{c}0.016 \\
(0.014)\end{array}$ & $\begin{array}{c}0.030^{* *} \\
(0.015)\end{array}$ & $\begin{array}{c}0.037^{* *} \\
(0.017)\end{array}$ & $\begin{array}{c}0.055^{* * *} \\
(0.019)\end{array}$ & $\begin{array}{c}0.142^{* * *} \\
(0.021)\end{array}$ & $\begin{array}{c}0.142^{* * *} \\
(0.023)\end{array}$ & $\begin{array}{c}0.147^{* * *} \\
(0.027)\end{array}$ & $\begin{array}{c}0.149^{* * *} \\
(0.029)\end{array}$ \\
\hline Prev. Adm. Hosp. & $\begin{array}{c}-0.193^{* * *} \\
(0.054)\end{array}$ & $\begin{array}{c}-0.181^{* * *} \\
(0.057)\end{array}$ & $\begin{array}{l}-0.072 \\
(0.110)\end{array}$ & $\begin{array}{l}-0.012 \\
(0.123)\end{array}$ & $\begin{array}{c}-0.077^{* *} \\
(0.034)\end{array}$ & $\begin{array}{l}-0.043 \\
(0.035)\end{array}$ & $\begin{array}{c}0.046 \\
(0.077)\end{array}$ & $\begin{array}{c}0.076 \\
(0.080)\end{array}$ & $\begin{array}{c}-0.117^{* * *} \\
(0.036)\end{array}$ & $\begin{array}{c}-0.138^{* * *} \\
(0.035)\end{array}$ & $\begin{array}{l}-0.118 \\
(0.076)\end{array}$ & $\begin{array}{l}-0.088 \\
(0.081)\end{array}$ \\
\hline Univ. Hosp. per Capita & $\begin{array}{c}326.671 \\
(2292.686)\end{array}$ & $\begin{array}{c}1375.667 \\
(2624.696)\end{array}$ & $\begin{array}{c}-933.988 \\
(2518.902)\end{array}$ & $\begin{array}{l}-1774.439 \\
(2838.598)\end{array}$ & $\begin{array}{c}191.199 \\
(1626.612)\end{array}$ & $\begin{array}{c}945.314 \\
(1796.919)\end{array}$ & $\begin{array}{c}-775.477 \\
(1839.476)\end{array}$ & $\begin{array}{l}-1182.097 \\
(2041.991)\end{array}$ & $\begin{array}{c}135.472 \\
(1861.004)\end{array}$ & $\begin{array}{c}430.354 \\
(2069.381)\end{array}$ & $\begin{array}{c}-158.510 \\
(2067.180)\end{array}$ & $\begin{array}{c}-592.342 \\
(2161.667)\end{array}$ \\
\hline Ins. Concentration & $\begin{array}{l}-0.078 \\
(0.048)\end{array}$ & $\begin{array}{l}-0.065 \\
(0.058)\end{array}$ & $\begin{array}{c}-0.097^{*} \\
(0.056)\end{array}$ & $\begin{array}{l}-0.038 \\
(0.070)\end{array}$ & $\begin{array}{l}-0.024 \\
(0.028)\end{array}$ & $\begin{array}{l}-0.010 \\
(0.033)\end{array}$ & $\begin{array}{l}-0.011 \\
(0.029)\end{array}$ & $\begin{array}{c}0.012 \\
(0.036)\end{array}$ & $\begin{array}{l}-0.054 \\
(0.041)\end{array}$ & $\begin{array}{l}-0.055 \\
(0.047)\end{array}$ & $\begin{array}{c}-0.086^{*} \\
(0.044)\end{array}$ & $\begin{array}{l}-0.051 \\
(0.052)\end{array}$ \\
\hline HMO & $\begin{array}{c}0.105^{* * *} \\
(0.040)\end{array}$ & $\begin{array}{c}0.098^{* *} \\
(0.046)\end{array}$ & $\begin{array}{c}0.122^{* *} \\
(0.049)\end{array}$ & $\begin{array}{c}0.083 \\
(0.056)\end{array}$ & $\begin{array}{c}0.015 \\
(0.027)\end{array}$ & $\begin{array}{c}0.020 \\
(0.031)\end{array}$ & $\begin{array}{c}0.027 \\
(0.034)\end{array}$ & $\begin{array}{c}0.021 \\
(0.038)\end{array}$ & $\begin{array}{c}0.091^{* * * *} \\
(0.028)\end{array}$ & $\begin{array}{c}0.077^{* * *} \\
(0.029)\end{array}$ & $\begin{array}{c}0.095^{* * *} \\
(0.035)\end{array}$ & $\begin{array}{l}0.062^{*} \\
(0.036)\end{array}$ \\
\hline PPO & $\begin{array}{c}0.111^{* * *} \\
(0.030)\end{array}$ & $\begin{array}{l}0.086^{* *} \\
(0.033)\end{array}$ & $\begin{array}{c}0.143 * * * \\
(0.037)\end{array}$ & $\begin{array}{c}0.100^{* *} \\
(0.041)\end{array}$ & $\begin{array}{c}0.009 \\
(0.022)\end{array}$ & $\begin{array}{c}0.013 \\
(0.024)\end{array}$ & $\begin{array}{c}0.028 \\
(0.027)\end{array}$ & $\begin{array}{c}0.018 \\
(0.029)\end{array}$ & $\begin{array}{c}0.102^{* * *} \\
(0.019)\end{array}$ & $\begin{array}{c}0.074^{* * *} \\
(0.021)\end{array}$ & $\begin{array}{c}0.116^{* * *} \\
(0.024)\end{array}$ & $\begin{array}{c}0.081^{* * * *} \\
(0.025)\end{array}$ \\
\hline POS & $\begin{array}{c}0.104^{* * *} \\
(0.039)\end{array}$ & $\begin{array}{c}0.092^{* *} \\
(0.045)\end{array}$ & $\begin{array}{c}0.099^{* *} \\
(0.050)\end{array}$ & $\begin{array}{c}0.065 \\
(0.054)\end{array}$ & $\begin{array}{l}-0.017 \\
(0.029)\end{array}$ & $\begin{array}{l}-0.014 \\
(0.031)\end{array}$ & $\begin{array}{l}-0.014 \\
(0.035)\end{array}$ & $\begin{array}{l}-0.025 \\
(0.037)\end{array}$ & $\begin{array}{c}0.121^{* * *} \\
(0.025)\end{array}$ & $\begin{array}{c}0.106^{* * *} \\
(0.027)\end{array}$ & $\begin{array}{c}0.113^{* * *} \\
(0.031)\end{array}$ & $\begin{array}{c}0.089^{* * *} \\
(0.033)\end{array}$ \\
\hline CDHP & $\begin{array}{l}-0.114 \\
(0.079)\end{array}$ & $\begin{array}{l}-0.110 \\
(0.082)\end{array}$ & $\begin{array}{l}-0.073 \\
(0.095)\end{array}$ & $\begin{array}{l}-0.130 \\
(0.104)\end{array}$ & $\begin{array}{c}-0.153^{* * *} \\
(0.055)\end{array}$ & $\begin{array}{c}-0.124^{* *} \\
(0.057)\end{array}$ & $\begin{array}{c}-0.145^{* *} \\
(0.063)\end{array}$ & $\begin{array}{c}-0.153^{* *} \\
(0.067)\end{array}$ & $\begin{array}{c}0.039 \\
(0.044)\end{array}$ & $\begin{array}{c}0.014 \\
(0.046)\end{array}$ & $\begin{array}{c}0.072 \\
(0.059)\end{array}$ & $\begin{array}{c}0.023 \\
(0.064)\end{array}$ \\
\hline HDHP & $\begin{array}{c}0.213 \\
(0.356)\end{array}$ & $\begin{array}{c}0.181 \\
(0.349)\end{array}$ & $\begin{array}{c}0.567 * * * \\
(0.197)\end{array}$ & $\begin{array}{c}0.488^{* * *} \\
(0.187)\end{array}$ & $\begin{array}{c}0.050 \\
(0.206)\end{array}$ & $\begin{array}{c}0.051 \\
(0.202)\end{array}$ & $\begin{array}{c}0.161 \\
(0.192)\end{array}$ & $\begin{array}{c}0.136 \\
(0.189)\end{array}$ & $\begin{array}{c}0.163 \\
(0.212)\end{array}$ & $\begin{array}{c}0.129 \\
(0.208)\end{array}$ & $\begin{array}{c}0.406^{* *} \\
(0.173)\end{array}$ & $\begin{array}{c}0.352 * * \\
(0.169)\end{array}$ \\
\hline Hosp. per Capita & $\begin{array}{c}439.453 \\
(2193.162)\end{array}$ & $\begin{array}{c}-761.596 \\
(2332.473)\end{array}$ & $\begin{array}{c}-10.284 \\
(2610.664)\end{array}$ & $\begin{array}{l}-2265.493 \\
(2802.647)\end{array}$ & $\begin{array}{c}805.586 \\
(1641.455)\end{array}$ & $\begin{array}{c}525.340 \\
(1807.691)\end{array}$ & $\begin{array}{c}381.067 \\
(1901.961)\end{array}$ & $\begin{array}{c}-813.931 \\
(2060.045)\end{array}$ & $\begin{array}{c}-366.133 \\
(1829.466)\end{array}$ & $\begin{array}{l}-1286.936 \\
(1924.430)\end{array}$ & $\begin{array}{c}-391.352 \\
(2057.697)\end{array}$ & $\begin{array}{l}-1451.562 \\
(2201.555)\end{array}$ \\
\hline Cardiologists per Firm & $\begin{array}{l}-0.002 \\
(0.003)\end{array}$ & $\begin{array}{l}-0.005 \\
(0.003)\end{array}$ & $\begin{array}{l}-0.001 \\
(0.003)\end{array}$ & $\begin{array}{l}-0.004 \\
(0.004)\end{array}$ & $\begin{array}{c}0.000 \\
(0.002)\end{array}$ & $\begin{array}{l}-0.001 \\
(0.002)\end{array}$ & $\begin{array}{c}0.001 \\
(0.002)\end{array}$ & $\begin{array}{l}-0.001 \\
(0.003)\end{array}$ & $\begin{array}{l}-0.002 \\
(0.002)\end{array}$ & $\begin{array}{l}-0.004 \\
(0.003)\end{array}$ & $\begin{array}{l}-0.002 \\
(0.002)\end{array}$ & $\begin{array}{l}-0.004 \\
(0.003)\end{array}$ \\
\hline Cardiologists per Capita & 486.134 & 566.353 & $788.410^{* *}$ & $1196.204^{* * *}$ & 209.425 & 164.292 & $486.586^{*}$ & $725.607^{* *}$ & 276.709 & 402.061 & 301.824 & 470.597 \\
\hline
\end{tabular}




\begin{tabular}{|c|c|c|c|c|c|c|c|c|c|c|c|c|}
\hline & $(316.517)$ & $(349.744)$ & $(398.578)$ & $(430.273)$ & $(226.962)$ & $(251.677)$ & $(272.234)$ & $(303.023)$ & $(263.126)$ & $(265.782)$ & $(297.047)$ & $(305.668)$ \\
\hline Persons per Sq. Mile & $\begin{array}{l}-0.000 \\
(0.000)\end{array}$ & $\begin{array}{l}-0.000 \\
(0.000)\end{array}$ & $\begin{array}{c}0.000 \\
(0.000)\end{array}$ & $\begin{array}{l}-0.000 \\
(0.000)\end{array}$ & $\begin{array}{l}-0.000 \\
(0.000)\end{array}$ & $\begin{array}{l}-0.000 \\
(0.000)\end{array}$ & $\begin{array}{c}0.000 \\
(0.000)\end{array}$ & $\begin{array}{l}-0.000 \\
(0.000)\end{array}$ & $\begin{array}{l}-0.000 \\
(0.000)\end{array}$ & $\begin{array}{l}-0.000 \\
(0.000)\end{array}$ & $\begin{array}{l}-0.000 \\
(0.000)\end{array}$ & $\begin{array}{l}-0.000 \\
(0.000)\end{array}$ \\
\hline Log Med. Inc. & $\begin{array}{c}0.365 * * \\
(0.168)\end{array}$ & $\begin{array}{c}0.431^{* *} \\
(0.191)\end{array}$ & $\begin{array}{l}0.376^{* *} \\
(0.190)\end{array}$ & $\begin{array}{l}0.437^{* *} \\
(0.206)\end{array}$ & $\begin{array}{l}0.166^{*} \\
(0.089)\end{array}$ & $\begin{array}{c}0.199^{* *} \\
(0.097)\end{array}$ & $\begin{array}{l}0.205^{* *} \\
(0.101)\end{array}$ & $\begin{array}{l}0.214^{* *} \\
(0.108)\end{array}$ & $\begin{array}{c}0.199 \\
(0.123)\end{array}$ & $\begin{array}{l}0.233^{*} \\
(0.134)\end{array}$ & $\begin{array}{c}0.171 \\
(0.134)\end{array}$ & $\begin{array}{c}0.222 \\
(0.140)\end{array}$ \\
\hline Log Hosp. Costs per Emp & $\begin{array}{c}0.009 \\
(0.031)\end{array}$ & $\begin{array}{l}-0.010 \\
(0.036)\end{array}$ & $\begin{array}{l}-0.019 \\
(0.040)\end{array}$ & $\begin{array}{l}-0.050 \\
(0.045)\end{array}$ & $\begin{array}{c}0.025 \\
(0.023)\end{array}$ & $\begin{array}{c}0.022 \\
(0.026)\end{array}$ & $\begin{array}{l}-0.004 \\
(0.028)\end{array}$ & $\begin{array}{l}-0.015 \\
(0.031)\end{array}$ & $\begin{array}{l}-0.016 \\
(0.021)\end{array}$ & $\begin{array}{l}-0.032 \\
(0.024)\end{array}$ & $\begin{array}{l}-0.015 \\
(0.026)\end{array}$ & $\begin{array}{l}-0.035 \\
(0.029)\end{array}$ \\
\hline Log Med. Rent & $\begin{array}{c}0.084 \\
(0.210)\end{array}$ & $\begin{array}{c}0.126 \\
(0.244)\end{array}$ & $\begin{array}{c}0.032 \\
(0.242)\end{array}$ & $\begin{array}{l}0.096 \\
(0.264)\end{array}$ & $\begin{array}{c}0.054 \\
(0.129)\end{array}$ & $\begin{array}{c}0.025 \\
(0.138)\end{array}$ & $\begin{array}{c}0.014 \\
(0.147)\end{array}$ & $\begin{array}{c}0.000 \\
(0.153)\end{array}$ & $\begin{array}{c}0.029 \\
(0.149)\end{array}$ & $\begin{array}{c}0.101 \\
(0.171)\end{array}$ & $\begin{array}{c}0.019 \\
(0.167)\end{array}$ & $\begin{array}{c}0.096 \\
(0.179)\end{array}$ \\
\hline Log Med. House Val. & $\begin{array}{l}-0.184 \\
(0.118)\end{array}$ & $\begin{array}{l}-0.232^{*} \\
(0.135)\end{array}$ & $\begin{array}{l}-0.207 \\
(0.139)\end{array}$ & $\begin{array}{l}-0.225 \\
(0.152)\end{array}$ & $\begin{array}{l}-0.013 \\
(0.077)\end{array}$ & $\begin{array}{l}-0.027 \\
(0.083)\end{array}$ & $\begin{array}{l}-0.004 \\
(0.084)\end{array}$ & $\begin{array}{c}0.014 \\
(0.090)\end{array}$ & $\begin{array}{c}-0.171^{*} \\
(0.088)\end{array}$ & $\begin{array}{c}-0.205^{* *} \\
(0.095)\end{array}$ & $\begin{array}{c}-0.202^{* *} \\
(0.098)\end{array}$ & $\begin{array}{c}-0.239^{* *} \\
(0.103)\end{array}$ \\
\hline Frac. Heavy Smokers & $\begin{array}{l}-0.469 \\
(0.463)\end{array}$ & $\begin{array}{l}-0.653 \\
(0.495)\end{array}$ & $\begin{array}{l}-0.368 \\
(0.560)\end{array}$ & $\begin{array}{l}-0.615 \\
(0.565)\end{array}$ & $\begin{array}{l}-0.224 \\
(0.334)\end{array}$ & $\begin{array}{l}-0.299 \\
(0.344)\end{array}$ & $\begin{array}{l}-0.216 \\
(0.361)\end{array}$ & $\begin{array}{l}-0.385 \\
(0.349)\end{array}$ & $\begin{array}{l}-0.244 \\
(0.343)\end{array}$ & $\begin{array}{l}-0.354 \\
(0.368)\end{array}$ & $\begin{array}{l}-0.151 \\
(0.387)\end{array}$ & $\begin{array}{l}-0.230 \\
(0.408)\end{array}$ \\
\hline Frac. Obese & $\begin{array}{l}-0.418 \\
(0.408)\end{array}$ & $\begin{array}{l}-0.342 \\
(0.443)\end{array}$ & $\begin{array}{l}-0.440 \\
(0.520)\end{array}$ & $\begin{array}{l}-0.116 \\
(0.537)\end{array}$ & $\begin{array}{c}0.240 \\
(0.270)\end{array}$ & $\begin{array}{c}0.198 \\
(0.296)\end{array}$ & $\begin{array}{c}0.498 \\
(0.333)\end{array}$ & $\begin{array}{l}0.644^{*} \\
(0.344)\end{array}$ & $\begin{array}{c}-0.658^{* *} \\
(0.302)\end{array}$ & $\begin{array}{c}-0.539^{*} \\
(0.314)\end{array}$ & $\begin{array}{c}-0.938^{* * *} \\
(0.348)\end{array}$ & $\begin{array}{c}-0.760^{* *} \\
(0.363)\end{array}$ \\
\hline Treated Prevalence (non card) & $\begin{array}{c}0.510^{* * *} \\
(0.196)\end{array}$ & $\begin{array}{l}0.440^{* *} \\
(0.222)\end{array}$ & $\begin{array}{l}0.598^{* *} \\
(0.235)\end{array}$ & $\begin{array}{l}0.545^{* *} \\
(0.250)\end{array}$ & $\begin{array}{c}0.151 \\
(0.131)\end{array}$ & $\begin{array}{c}0.151 \\
(0.142)\end{array}$ & $\begin{array}{c}0.188 \\
(0.144)\end{array}$ & $\begin{array}{c}0.154 \\
(0.153)\end{array}$ & $\begin{array}{l}0.358^{* *} \\
(0.143)\end{array}$ & $\begin{array}{l}0.290^{*} \\
(0.157)\end{array}$ & $\begin{array}{c}0.410^{* *} \\
(0.173)\end{array}$ & $\begin{array}{l}0.391^{* *} \\
(0.184)\end{array}$ \\
\hline Serv. Util. Index (non card) & $\begin{array}{c}0.281 \\
(0.260)\end{array}$ & $\begin{array}{c}0.219 \\
(0.305)\end{array}$ & $\begin{array}{c}0.677^{* *} \\
(0.302)\end{array}$ & $\begin{array}{l}0.582^{*} \\
(0.353)\end{array}$ & $\begin{array}{l}-0.104 \\
(0.178)\end{array}$ & $\begin{array}{l}-0.082 \\
(0.191)\end{array}$ & $\begin{array}{c}0.257 \\
(0.202)\end{array}$ & $\begin{array}{c}0.220 \\
(0.212)\end{array}$ & $\begin{array}{c}0.385^{* *} \\
(0.180)\end{array}$ & $\begin{array}{c}0.302 \\
(0.212)\end{array}$ & $\begin{array}{c}0.420^{* *} \\
(0.211)\end{array}$ & $\begin{array}{c}0.362 \\
(0.245)\end{array}$ \\
\hline Observations & 11846 & 9836 & 6862 & 5739 & 11846 & 9836 & 6862 & 5739 & 11846 & 9836 & 6862 & 5739 \\
\hline
\end{tabular}


Table A3: Any Echocardiogram, Cardiovascular Stress Test, Cardiac Catheterization, Angioplasty, CABG

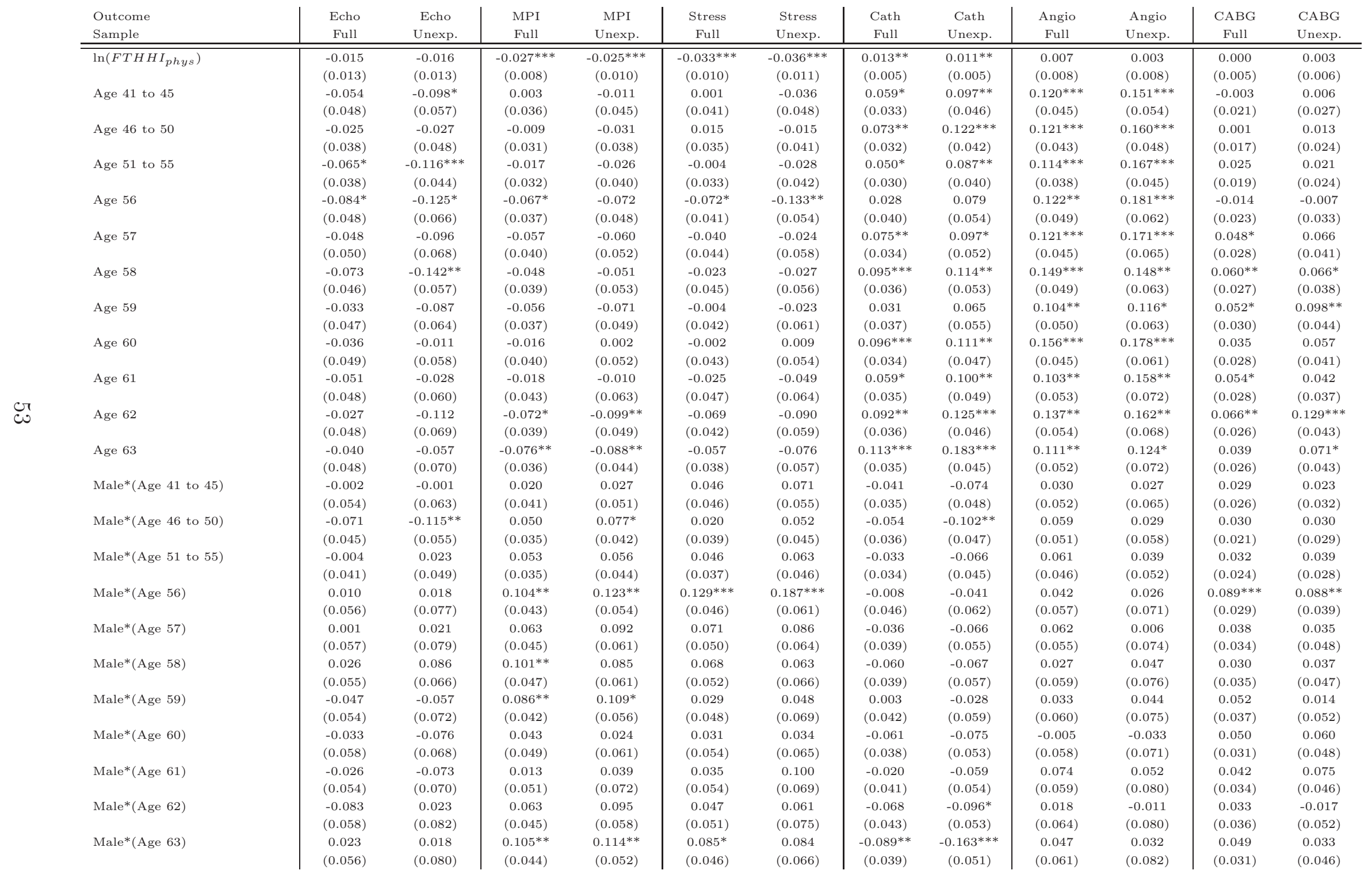




\begin{tabular}{|c|c|c|c|c|c|c|c|c|c|c|c|c|}
\hline Male & $\begin{array}{l}-0.014 \\
(0.036)\end{array}$ & $\begin{array}{l}-0.013 \\
(0.043)\end{array}$ & $\begin{array}{l}-0.049 \\
(0.031)\end{array}$ & $\begin{array}{l}-0.056 \\
(0.037)\end{array}$ & $\begin{array}{l}-0.023 \\
(0.033)\end{array}$ & $\begin{array}{l}-0.037 \\
(0.038)\end{array}$ & $\begin{array}{c}0.078^{* *} \\
(0.033)\end{array}$ & $\begin{array}{c}0.110^{* *} \\
(0.043)\end{array}$ & $\begin{array}{l}0.101 * * \\
(0.042)\end{array}$ & $\begin{array}{c}0.131 * * * \\
(0.048)\end{array}$ & $\begin{array}{l}-0.001 \\
(0.019)\end{array}$ & $\begin{array}{l}-0.008 \\
(0.024)\end{array}$ \\
\hline ICD9-410.0 & $\begin{array}{c}0.125^{* * *} \\
(0.026)\end{array}$ & $\begin{array}{c}0.131^{* * *} \\
(0.034)\end{array}$ & $\begin{array}{c}-0.047^{* *} \\
(0.021)\end{array}$ & $\begin{array}{l}-0.031 \\
(0.029)\end{array}$ & $\begin{array}{c}0.019 \\
(0.025)\end{array}$ & $\begin{array}{c}0.041 \\
(0.034)\end{array}$ & $\begin{array}{c}0.164^{* * *} \\
(0.018)\end{array}$ & $\begin{array}{c}0.148^{* * *} \\
(0.025)\end{array}$ & $\begin{array}{c}0.300^{* * *} \\
(0.026)\end{array}$ & $\begin{array}{c}0.287^{* * *} \\
(0.034)\end{array}$ & $\begin{array}{l}-0.008 \\
(0.014)\end{array}$ & $\begin{array}{c}0.010 \\
(0.020)\end{array}$ \\
\hline ICD9-410.1 & $\begin{array}{c}0.129^{* * *} \\
(0.017)\end{array}$ & $\begin{array}{c}0.122^{* * *} \\
(0.022)\end{array}$ & $\begin{array}{c}-0.057^{* * *} \\
(0.016)\end{array}$ & $\begin{array}{c}-0.056^{* * *} \\
(0.021)\end{array}$ & $\begin{array}{l}-0.001 \\
(0.020)\end{array}$ & $\begin{array}{l}-0.001 \\
(0.025)\end{array}$ & $\begin{array}{c}0.186^{* * *} \\
(0.016)\end{array}$ & $\begin{array}{c}0.157^{* * *} * \\
(0.019)\end{array}$ & $\begin{array}{c}0.363^{* * *} \\
(0.019)\end{array}$ & $\begin{array}{c}0.354^{* * *} \\
(0.025)\end{array}$ & $\begin{array}{c}0.003 \\
(0.012)\end{array}$ & $\begin{array}{l}-0.005 \\
(0.013)\end{array}$ \\
\hline ICD9-410.2 & $\begin{array}{c}0.024 \\
(0.028)\end{array}$ & $\begin{array}{c}0.003 \\
(0.035)\end{array}$ & $\begin{array}{l}-0.013 \\
(0.022)\end{array}$ & $\begin{array}{c}0.011 \\
(0.033)\end{array}$ & $\begin{array}{c}0.008 \\
(0.026)\end{array}$ & $\begin{array}{c}0.009 \\
(0.037)\end{array}$ & $\begin{array}{c}0.184^{* * *} \\
(0.020)\end{array}$ & $\begin{array}{c}0.165^{* * *} \\
(0.021)\end{array}$ & $\begin{array}{c}0.352^{* * *} \\
(0.027)\end{array}$ & $\begin{array}{c}0.331^{* * *} \\
(0.034)\end{array}$ & $\begin{array}{l}-0.015 \\
(0.014)\end{array}$ & $\begin{array}{l}-0.008 \\
(0.019)\end{array}$ \\
\hline ICD9-410.3 & $\begin{array}{l}0.055^{*} \\
(0.031)\end{array}$ & $\begin{array}{c}0.059 \\
(0.037)\end{array}$ & $\begin{array}{c}-0.058^{* *} \\
(0.025)\end{array}$ & $\begin{array}{l}-0.034 \\
(0.034)\end{array}$ & $\begin{array}{l}-0.005 \\
(0.030)\end{array}$ & $\begin{array}{c}0.014 \\
(0.037)\end{array}$ & $\begin{array}{c}0.223 * * * \\
(0.018)\end{array}$ & $\begin{array}{c}0.177^{* * *} \\
(0.022)\end{array}$ & $\begin{array}{c}0.455^{* * *} \\
(0.024)\end{array}$ & $\begin{array}{c}0.401 * * * \\
(0.032)\end{array}$ & $\begin{array}{l}-0.020 \\
(0.016)\end{array}$ & $\begin{array}{l}-0.019 \\
(0.020)\end{array}$ \\
\hline ICD9-410.4 & $\begin{array}{l}-0.005 \\
(0.017)\end{array}$ & $\begin{array}{l}-0.020 \\
(0.024)\end{array}$ & $\begin{array}{c}-0.046^{* * *} \\
(0.016)\end{array}$ & $\begin{array}{l}-0.031 \\
(0.020)\end{array}$ & $\begin{array}{c}0.000 \\
(0.018)\end{array}$ & $\begin{array}{c}0.026 \\
(0.023)\end{array}$ & $\begin{array}{c}0.196 * * * \\
(0.017)\end{array}$ & $\begin{array}{c}0.173^{* * *} \\
(0.019)\end{array}$ & $\begin{array}{c}0.414^{* * *} \\
(0.016)\end{array}$ & $\begin{array}{c}0.404^{* * *} \\
(0.023)\end{array}$ & $\begin{array}{l}-0.005 \\
(0.009)\end{array}$ & $\begin{array}{l}-0.008 \\
(0.012)\end{array}$ \\
\hline ICD9-410.5 & $\begin{array}{c}0.017 \\
(0.036)\end{array}$ & $\begin{array}{c}0.032 \\
(0.044)\end{array}$ & $\begin{array}{c}-0.056^{*} \\
(0.031)\end{array}$ & $\begin{array}{l}-0.045 \\
(0.039)\end{array}$ & $\begin{array}{l}-0.035 \\
(0.035)\end{array}$ & $\begin{array}{l}-0.042 \\
(0.041)\end{array}$ & $\begin{array}{c}0.195^{* * *} \\
(0.020)\end{array}$ & $\begin{array}{c}0.193^{* * *} \\
(0.023)\end{array}$ & $\begin{array}{c}0.322^{* * *} \\
(0.031)\end{array}$ & $\begin{array}{c}0.347^{* * *} \\
(0.040)\end{array}$ & $\begin{array}{l}-0.032^{*} \\
(0.017)\end{array}$ & $\begin{array}{c}-0.041^{* *} \\
(0.021)\end{array}$ \\
\hline ICD9-410.6 & $\begin{array}{c}0.036 \\
(0.063)\end{array}$ & $\begin{array}{l}-0.070 \\
(0.076)\end{array}$ & $\begin{array}{c}-0.109 * * * \\
(0.042)\end{array}$ & $\begin{array}{l}-0.067 \\
(0.061)\end{array}$ & $\begin{array}{l}-0.020 \\
(0.050)\end{array}$ & $\begin{array}{c}0.038 \\
(0.072)\end{array}$ & $\begin{array}{c}0.182^{* * *} \\
(0.042)\end{array}$ & $\begin{array}{l}0.111^{*} \\
(0.057)\end{array}$ & $\begin{array}{c}0.336^{* * * *} \\
(0.054)\end{array}$ & $\begin{array}{c}0.289^{* * *} \\
(0.066)\end{array}$ & $\begin{array}{c}0.001 \\
(0.034)\end{array}$ & $\begin{array}{l}-0.042 \\
(0.036)\end{array}$ \\
\hline ICD9-410.7 & $\begin{array}{l}-0.011 \\
(0.016)\end{array}$ & $\begin{array}{l}-0.020 \\
(0.020)\end{array}$ & $\begin{array}{c}-0.072^{* * *} \\
(0.015)\end{array}$ & $\begin{array}{c}-0.056^{* * *} \\
(0.019)\end{array}$ & $\begin{array}{c}-0.058^{* * *} \\
(0.016)\end{array}$ & $\begin{array}{c}-0.040^{*} \\
(0.021)\end{array}$ & $\begin{array}{c}0.192^{* * *} \\
(0.016)\end{array}$ & $\begin{array}{c}0.162^{* * *} \\
(0.018)\end{array}$ & $\begin{array}{c}0.164^{* * *} \\
(0.016)\end{array}$ & $\begin{array}{c}0.159^{* * *} \\
(0.022)\end{array}$ & $\begin{array}{c}0.051^{* * *} \\
(0.009)\end{array}$ & $\begin{array}{c}0.048^{* * *} \\
(0.011)\end{array}$ \\
\hline ICD9-410.8 & $\begin{array}{c}0.012 \\
(0.042)\end{array}$ & $\begin{array}{l}-0.023 \\
(0.058)\end{array}$ & $\begin{array}{c}-0.072^{* *} \\
(0.030)\end{array}$ & $\begin{array}{c}-0.119 * * * \\
(0.039)\end{array}$ & $\begin{array}{l}-0.067^{*} \\
(0.035)\end{array}$ & $\begin{array}{l}-0.075 \\
(0.049)\end{array}$ & $\begin{array}{l}0.066^{* *} \\
(0.031)\end{array}$ & $\begin{array}{c}0.097^{* * *} * \\
(0.035)\end{array}$ & $\begin{array}{l}0.085^{* *} \\
(0.039)\end{array}$ & $\begin{array}{l}0.101^{*} \\
(0.054)\end{array}$ & $\begin{array}{c}0.016 \\
(0.024)\end{array}$ & $\begin{array}{c}0.027 \\
(0.038)\end{array}$ \\
\hline Charlson & $\begin{array}{c}0.010 \\
(0.013)\end{array}$ & $\begin{array}{l}-0.034 \\
(0.027)\end{array}$ & $\begin{array}{c}0.009 \\
(0.010)\end{array}$ & $\begin{array}{c}0.003 \\
(0.018)\end{array}$ & $\begin{array}{c}-0.024^{* *} \\
(0.011)\end{array}$ & $\begin{array}{l}-0.031 \\
(0.023)\end{array}$ & $\begin{array}{c}-0.019^{* *} \\
(0.008)\end{array}$ & $\begin{array}{l}-0.015 \\
(0.016)\end{array}$ & $\begin{array}{c}-0.049^{* * *} \\
(0.011)\end{array}$ & $\begin{array}{l}-0.037 \\
(0.023)\end{array}$ & $\begin{array}{c}0.008 \\
(0.007)\end{array}$ & $\begin{array}{c}0.007 \\
(0.015)\end{array}$ \\
\hline Charlson $^{2}$ & $\begin{array}{c}0.004 \\
(0.005)\end{array}$ & $\begin{array}{c}0.031^{* *} \\
(0.014)\end{array}$ & $\begin{array}{l}-0.002 \\
(0.003)\end{array}$ & $\begin{array}{c}0.002 \\
(0.010)\end{array}$ & $\begin{array}{c}0.005 \\
(0.004)\end{array}$ & $\begin{array}{c}0.014 \\
(0.012)\end{array}$ & $\begin{array}{l}-0.005 \\
(0.004)\end{array}$ & $\begin{array}{c}0.004 \\
(0.010)\end{array}$ & $\begin{array}{c}0.005 \\
(0.004)\end{array}$ & $\begin{array}{c}0.015 \\
(0.012)\end{array}$ & $\begin{array}{c}-0.004^{*} \\
(0.002)\end{array}$ & $\begin{array}{l}-0.005 \\
(0.007)\end{array}$ \\
\hline Charlson $^{3}$ & $\begin{array}{l}-0.000 \\
(0.000)\end{array}$ & $\begin{array}{c}-0.003^{* *} \\
(0.001)\end{array}$ & $\begin{array}{l}-0.000 \\
(0.000)\end{array}$ & $\begin{array}{l}-0.001 \\
(0.001)\end{array}$ & $\begin{array}{l}-0.000 \\
(0.000)\end{array}$ & $\begin{array}{l}-0.002 \\
(0.001)\end{array}$ & $\begin{array}{c}0.000 \\
(0.000)\end{array}$ & $\begin{array}{l}-0.001 \\
(0.001)\end{array}$ & $\begin{array}{l}-0.000 \\
(0.000)\end{array}$ & $\begin{array}{l}-0.001 \\
(0.001)\end{array}$ & $\begin{array}{c}0.000 \\
(0.000)\end{array}$ & $\begin{array}{c}0.000 \\
(0.001)\end{array}$ \\
\hline Employer & $\begin{array}{l}-0.017 \\
(0.012)\end{array}$ & $\begin{array}{l}-0.025^{*} \\
(0.014)\end{array}$ & $\begin{array}{l}-0.016 \\
(0.011)\end{array}$ & $\begin{array}{l}-0.015 \\
(0.015)\end{array}$ & $\begin{array}{l}-0.006 \\
(0.013)\end{array}$ & $\begin{array}{l}-0.000 \\
(0.016)\end{array}$ & $\begin{array}{c}0.007 \\
(0.007)\end{array}$ & $\begin{array}{l}0.014^{*} \\
(0.008)\end{array}$ & $\begin{array}{l}0.022^{*} \\
(0.012)\end{array}$ & $\begin{array}{l}0.029^{*} \\
(0.016)\end{array}$ & $\begin{array}{l}-0.007 \\
(0.008)\end{array}$ & $\begin{array}{l}-0.010 \\
(0.010)\end{array}$ \\
\hline Prev. Adm. Hosp. & $\begin{array}{c}0.028 \\
(0.029)\end{array}$ & $\begin{array}{c}0.054 \\
(0.061)\end{array}$ & $\begin{array}{c}0.003 \\
(0.023)\end{array}$ & $\begin{array}{c}-0.093^{* *} \\
(0.038)\end{array}$ & $\begin{array}{l}-0.001 \\
(0.026)\end{array}$ & $\begin{array}{l}-0.078 \\
(0.053)\end{array}$ & $\begin{array}{c}-0.143^{* * *} \\
(0.023)\end{array}$ & $\begin{array}{l}-0.016 \\
(0.038)\end{array}$ & $\begin{array}{c}-0.110^{* * *} \\
(0.027)\end{array}$ & $\begin{array}{c}0.065 \\
(0.050)\end{array}$ & $\begin{array}{c}-0.053^{* * *} \\
(0.015)\end{array}$ & $\begin{array}{c}-0.048^{*} \\
(0.026)\end{array}$ \\
\hline Univ. Hosp. per Capita & $\begin{array}{c}2593.794 \\
(1588.968)\end{array}$ & $\begin{array}{c}1957.624 \\
(1872.279)\end{array}$ & $\begin{array}{c}1520.697 \\
(1108.482)\end{array}$ & $\begin{array}{c}1991.280 \\
(1354.148)\end{array}$ & $\begin{array}{c}-887.934 \\
(1296.002)\end{array}$ & $\begin{array}{c}190.983 \\
(1560.327)\end{array}$ & $\begin{array}{l}-524.373 \\
(653.603)\end{array}$ & $\begin{array}{l}-265.645 \\
(701.641)\end{array}$ & $\begin{array}{c}721.870 \\
(1164.159)\end{array}$ & $\begin{array}{c}45.113 \\
(1327.782)\end{array}$ & $\begin{array}{l}-353.548 \\
(758.427)\end{array}$ & $\begin{array}{l}-386.812 \\
(878.822)\end{array}$ \\
\hline Ins. Concentration & $\begin{array}{l}-0.030 \\
(0.027)\end{array}$ & $\begin{array}{l}-0.039 \\
(0.030)\end{array}$ & $\begin{array}{c}0.000 \\
(0.019)\end{array}$ & $\begin{array}{l}-0.016 \\
(0.022)\end{array}$ & $\begin{array}{c}0.043 \\
(0.026)\end{array}$ & $\begin{array}{c}0.024 \\
(0.030)\end{array}$ & $\begin{array}{c}0.008 \\
(0.011)\end{array}$ & $\begin{array}{c}0.011 \\
(0.013)\end{array}$ & $\begin{array}{c}0.021 \\
(0.022)\end{array}$ & $\begin{array}{l}-0.018 \\
(0.027)\end{array}$ & $\begin{array}{c}0.033^{* * *} \\
(0.012)\end{array}$ & $\begin{array}{l}0.033^{* *} \\
(0.016)\end{array}$ \\
\hline HMO & $\begin{array}{l}-0.010 \\
(0.024)\end{array}$ & $\begin{array}{l}-0.011 \\
(0.031)\end{array}$ & $\begin{array}{l}-0.010 \\
(0.019)\end{array}$ & $\begin{array}{l}-0.003 \\
(0.023)\end{array}$ & $\begin{array}{c}0.011 \\
(0.026)\end{array}$ & $\begin{array}{l}-0.005 \\
(0.032)\end{array}$ & $\begin{array}{l}-0.003 \\
(0.013)\end{array}$ & $\begin{array}{c}0.004 \\
(0.018)\end{array}$ & $\begin{array}{l}0.035^{*} \\
(0.021)\end{array}$ & $\begin{array}{c}0.024 \\
(0.028)\end{array}$ & $\begin{array}{l}-0.005 \\
(0.014)\end{array}$ & $\begin{array}{l}-0.021 \\
(0.018)\end{array}$ \\
\hline $\mathrm{PPO}$ & $\begin{array}{l}-0.006 \\
(0.018)\end{array}$ & $\begin{array}{l}-0.014 \\
(0.022)\end{array}$ & $\begin{array}{c}0.008 \\
(0.015)\end{array}$ & $\begin{array}{c}0.006 \\
(0.019)\end{array}$ & $\begin{array}{c}0.025 \\
(0.016)\end{array}$ & $\begin{array}{c}0.009 \\
(0.021)\end{array}$ & $\begin{array}{c}0.012 \\
(0.009)\end{array}$ & $\begin{array}{l}0.028^{* *} \\
(0.013)\end{array}$ & $\begin{array}{c}0.020 \\
(0.015)\end{array}$ & $\begin{array}{c}0.032 \\
(0.021)\end{array}$ & $\begin{array}{l}-0.009 \\
(0.012)\end{array}$ & $\begin{array}{l}-0.022 \\
(0.016)\end{array}$ \\
\hline POS & $\begin{array}{l}-0.022 \\
(0.023)\end{array}$ & $\begin{array}{l}-0.043 \\
(0.028)\end{array}$ & $\begin{array}{c}0.030 \\
(0.021)\end{array}$ & $\begin{array}{c}0.018 \\
(0.025)\end{array}$ & $\begin{array}{c}0.056^{* *} \\
(0.023)\end{array}$ & $\begin{array}{c}0.021 \\
(0.028)\end{array}$ & $\begin{array}{l}-0.007 \\
(0.012)\end{array}$ & $\begin{array}{l}-0.000 \\
(0.017)\end{array}$ & $\begin{array}{l}0.033^{*} \\
(0.020)\end{array}$ & $\begin{array}{c}0.031 \\
(0.026)\end{array}$ & $\begin{array}{l}-0.024^{*} \\
(0.014)\end{array}$ & $\begin{array}{c}-0.046 * * * \\
(0.016)\end{array}$ \\
\hline CDHP & $\begin{array}{l}-0.041 \\
(0.035)\end{array}$ & $\begin{array}{l}-0.044 \\
(0.039)\end{array}$ & $\begin{array}{l}-0.016 \\
(0.031)\end{array}$ & $\begin{array}{l}-0.008 \\
(0.036)\end{array}$ & $\begin{array}{c}0.010 \\
(0.037)\end{array}$ & $\begin{array}{l}-0.011 \\
(0.045)\end{array}$ & $\begin{array}{c}0.003 \\
(0.022)\end{array}$ & $\begin{array}{c}0.007 \\
(0.029)\end{array}$ & $\begin{array}{l}-0.021 \\
(0.035)\end{array}$ & $\begin{array}{l}-0.027 \\
(0.042)\end{array}$ & $\begin{array}{l}-0.023 \\
(0.024)\end{array}$ & $\begin{array}{l}-0.026 \\
(0.028)\end{array}$ \\
\hline HDHP & $\begin{array}{l}-0.283 \\
(0.184)\end{array}$ & $\begin{array}{l}-0.310 \\
(0.223)\end{array}$ & $\begin{array}{c}0.063 \\
(0.163)\end{array}$ & $\begin{array}{c}0.042 \\
(0.189)\end{array}$ & $\begin{array}{c}0.205 \\
(0.176)\end{array}$ & $\begin{array}{c}0.099 \\
(0.207)\end{array}$ & $\begin{array}{c}0.008 \\
(0.131)\end{array}$ & $\begin{array}{c}0.121 * * * \\
(0.039)\end{array}$ & $\begin{array}{c}0.035 \\
(0.139)\end{array}$ & $\begin{array}{l}0.230 * * \\
(0.097)\end{array}$ & $\begin{array}{c}0.035 \\
(0.132)\end{array}$ & $\begin{array}{c}0.068 \\
(0.196)\end{array}$ \\
\hline Hosp. per Capita & $\begin{array}{c}1075.209 \\
(1497.728)\end{array}$ & $\begin{array}{c}1995.141 \\
(1737.756)\end{array}$ & $\begin{array}{c}-350.608 \\
(1099.005)\end{array}$ & $\begin{array}{c}456.869 \\
(1350.178)\end{array}$ & $\begin{array}{c}754.530 \\
(1398.502)\end{array}$ & $\begin{array}{c}1346.454 \\
(1597.612)\end{array}$ & $\begin{array}{c}835.368 \\
(675.799)\end{array}$ & $\begin{array}{c}26.429 \\
(770.303)\end{array}$ & $\begin{array}{c}-151.445 \\
(1156.014)\end{array}$ & $\begin{array}{c}-151.394 \\
(1346.675)\end{array}$ & $\begin{array}{c}219.343 \\
(751.567)\end{array}$ & $\begin{array}{l}-126.114 \\
(823.167)\end{array}$ \\
\hline Cardiologists per Firm & $\begin{array}{l}-0.001 \\
(0.003)\end{array}$ & $\begin{array}{l}-0.003 \\
(0.003)\end{array}$ & $\begin{array}{c}-0.004^{* *} \\
(0.002)\end{array}$ & $\begin{array}{l}-0.003 \\
(0.002)\end{array}$ & $\begin{array}{l}-0.002 \\
(0.002)\end{array}$ & $\begin{array}{l}-0.002 \\
(0.002)\end{array}$ & $\begin{array}{c}0.001 \\
(0.001)\end{array}$ & $\begin{array}{l}-0.000 \\
(0.001)\end{array}$ & $\begin{array}{c}0.001 \\
(0.001)\end{array}$ & $\begin{array}{c}0.000 \\
(0.002)\end{array}$ & $\begin{array}{l}-0.001 \\
(0.001)\end{array}$ & $\begin{array}{c}-0.002^{*} \\
(0.001)\end{array}$ \\
\hline Cardiologists per Capita & $\begin{array}{l}-111.693 \\
(213.534)\end{array}$ & $\begin{array}{c}122.713 \\
(264.011)\end{array}$ & $\begin{array}{c}189.848 \\
(162.057)\end{array}$ & $\begin{array}{c}122.211 \\
(199.256)\end{array}$ & $\begin{array}{c}159.782 \\
(175.625)\end{array}$ & $\begin{array}{c}115.169 \\
(208.555)\end{array}$ & $\begin{array}{c}-0.352 \\
(79.888)\end{array}$ & $\begin{array}{l}105.126 \\
(95.618)\end{array}$ & $\begin{array}{c}88.862 \\
(134.665)\end{array}$ & $\begin{array}{c}150.434 \\
(192.993)\end{array}$ & $\begin{array}{c}83.249 \\
(83.378)\end{array}$ & $\begin{array}{c}80.739 \\
(100.544)\end{array}$ \\
\hline Persons per Sq. Mile & 0.000 & 0.000 & -0.000 & 0.000 & $-0.000 *$ & 0.000 & $-0.000 * *$ & -0.000 & -0.000 & 0.000 & -0.000 & $-0.000 *$ \\
\hline
\end{tabular}




\begin{tabular}{|c|c|c|c|c|c|c|c|c|c|c|c|c|}
\hline & $(0.000)$ & $(0.000)$ & $(0.000)$ & $(0.000)$ & $(0.000)$ & $(0.000)$ & $(0.000)$ & $(0.000)$ & $(0.000)$ & $(0.000)$ & $(0.000)$ & $(0.000)$ \\
\hline Log Med. Inc. & $\begin{array}{l}-0.092 \\
(0.070)\end{array}$ & $\begin{array}{c}-0.083 \\
(0.081)\end{array}$ & $\begin{array}{l}-0.035 \\
(0.060)\end{array}$ & $\begin{array}{c}0.031 \\
(0.072)\end{array}$ & $\begin{array}{l}-0.062 \\
(0.068)\end{array}$ & $\begin{array}{c}0.017 \\
(0.078)\end{array}$ & $\begin{array}{c}0.097^{* *} \\
(0.039)\end{array}$ & $\begin{array}{l}0.069^{*} \\
(0.041)\end{array}$ & $\begin{array}{c}0.085 \\
(0.062)\end{array}$ & $\begin{array}{c}0.061 \\
(0.073)\end{array}$ & $\begin{array}{l}-0.006 \\
(0.034)\end{array}$ & $\begin{array}{c}0.036 \\
(0.043)\end{array}$ \\
\hline Log Hosp. Costs per Emp & $\begin{array}{c}-0.042^{* * *} \\
(0.021)\end{array}$ & $\begin{array}{c}-0.048^{* *} \\
(0.023)\end{array}$ & $\begin{array}{l}-0.013 \\
(0.017)\end{array}$ & $\begin{array}{l}-0.018 \\
(0.019)\end{array}$ & $\begin{array}{l}-0.011 \\
(0.018)\end{array}$ & $\begin{array}{l}-0.016 \\
(0.021)\end{array}$ & $\begin{array}{c}0.034^{* * * *} \\
(0.010)\end{array}$ & $\begin{array}{l}0.019^{*} \\
(0.011)\end{array}$ & $\begin{array}{c}0.034^{* *} \\
(0.015)\end{array}$ & $\begin{array}{l}0.031^{*} \\
(0.019)\end{array}$ & $\begin{array}{l}-0.002 \\
(0.010)\end{array}$ & $\begin{array}{c}0.010 \\
(0.011)\end{array}$ \\
\hline Log Med. Rent & $\begin{array}{c}0.127 \\
(0.112)\end{array}$ & $\begin{array}{c}0.115 \\
(0.123)\end{array}$ & $\begin{array}{c}-0.018 \\
(0.094)\end{array}$ & $\begin{array}{c}0.001 \\
(0.115)\end{array}$ & $\begin{array}{c}0.007 \\
(0.095)\end{array}$ & $\begin{array}{l}-0.035 \\
(0.117)\end{array}$ & $\begin{array}{c}-0.094^{*} \\
(0.052)\end{array}$ & $\begin{array}{l}-0.036 \\
(0.061)\end{array}$ & $\begin{array}{c}0.003 \\
(0.081)\end{array}$ & $\begin{array}{c}-0.062 \\
(0.097)\end{array}$ & $\begin{array}{l}-0.002 \\
(0.055)\end{array}$ & $\begin{array}{c}-0.019 \\
(0.063)\end{array}$ \\
\hline Log Med. House Val. & $\begin{array}{c}0.096 \\
(0.063)\end{array}$ & $\begin{array}{c}0.099 \\
(0.073)\end{array}$ & $\begin{array}{c}0.070 \\
(0.062)\end{array}$ & $\begin{array}{l}-0.016 \\
(0.072)\end{array}$ & $\begin{array}{c}0.162^{* * *} \\
(0.058)\end{array}$ & $\begin{array}{c}0.096 \\
(0.070)\end{array}$ & $\begin{array}{c}0.002 \\
(0.032)\end{array}$ & $\begin{array}{l}-0.014 \\
(0.036)\end{array}$ & $\begin{array}{l}-0.046 \\
(0.050)\end{array}$ & $\begin{array}{l}-0.031 \\
(0.065)\end{array}$ & $\begin{array}{c}0.026 \\
(0.033)\end{array}$ & $\begin{array}{c}0.022 \\
(0.041)\end{array}$ \\
\hline Frac. Heavy Smokers & $\begin{array}{c}0.298 \\
(0.308)\end{array}$ & $\begin{array}{c}0.117 \\
(0.328)\end{array}$ & $\begin{array}{l}-0.009 \\
(0.213)\end{array}$ & $\begin{array}{l}-0.065 \\
(0.248)\end{array}$ & $\begin{array}{c}0.146 \\
(0.260)\end{array}$ & $\begin{array}{c}0.050 \\
(0.271)\end{array}$ & $\begin{array}{l}0.323^{* *} \\
(0.126)\end{array}$ & $\begin{array}{c}0.305^{* * *} \\
(0.116)\end{array}$ & $\begin{array}{c}0.124 \\
(0.212)\end{array}$ & $\begin{array}{c}0.045 \\
(0.267)\end{array}$ & $\begin{array}{c}0.085 \\
(0.120)\end{array}$ & $\begin{array}{c}0.180 \\
(0.137)\end{array}$ \\
\hline Frac. Obese & $\begin{array}{l}0.432^{*} \\
(0.242)\end{array}$ & $\begin{array}{c}0.617^{* *} \\
(0.305)\end{array}$ & $\begin{array}{c}0.183 \\
(0.194)\end{array}$ & $\begin{array}{c}0.186 \\
(0.242)\end{array}$ & $\begin{array}{c}0.181 \\
(0.242)\end{array}$ & $\begin{array}{c}0.091 \\
(0.298)\end{array}$ & $\begin{array}{l}-0.110 \\
(0.110)\end{array}$ & $\begin{array}{l}-0.019 \\
(0.110)\end{array}$ & $\begin{array}{c}-0.332^{*} \\
(0.178)\end{array}$ & $\begin{array}{c}-0.299 \\
(0.229)\end{array}$ & $\begin{array}{l}0.206^{*} \\
(0.113)\end{array}$ & $\begin{array}{c}0.316^{* *} \\
(0.143)\end{array}$ \\
\hline Treated Prevalence (non card) & $\begin{array}{c}-0.357^{* * *} \\
(0.131)\end{array}$ & $\begin{array}{l}-0.260^{*} \\
(0.155)\end{array}$ & $\begin{array}{l}0.170^{*} \\
(0.099)\end{array}$ & $\begin{array}{l}0.232^{*} \\
(0.122)\end{array}$ & $\begin{array}{c}0.142 \\
(0.116)\end{array}$ & $\begin{array}{c}0.210 \\
(0.139)\end{array}$ & $\begin{array}{l}0.141^{* *} \\
(0.063)\end{array}$ & $\begin{array}{c}0.156^{* *} \\
(0.071)\end{array}$ & $\begin{array}{c}0.345^{* * * *} \\
(0.100)\end{array}$ & $\begin{array}{c}0.371^{* * * *} \\
(0.123)\end{array}$ & $\begin{array}{l}-0.111^{*} \\
(0.061)\end{array}$ & $\begin{array}{c}-0.141^{*} \\
(0.081)\end{array}$ \\
\hline Serv. Util. Index (non card) & $\begin{array}{l}-0.226 \\
(0.168)\end{array}$ & $\begin{array}{l}-0.135 \\
(0.191)\end{array}$ & $\begin{array}{l}-0.182 \\
(0.156)\end{array}$ & $\begin{array}{l}-0.028 \\
(0.185)\end{array}$ & $\begin{array}{l}-0.181 \\
(0.154)\end{array}$ & $\begin{array}{l}-0.049 \\
(0.191)\end{array}$ & $\begin{array}{c}0.106 \\
(0.088)\end{array}$ & $\begin{array}{c}0.150 \\
(0.101)\end{array}$ & $\begin{array}{c}0.192 \\
(0.141)\end{array}$ & $\begin{array}{c}0.253 \\
(0.174)\end{array}$ & $\begin{array}{c}0.074 \\
(0.081)\end{array}$ & $\begin{array}{c}0.037 \\
(0.095)\end{array}$ \\
\hline Observations & 11846 & 6862 & 11846 & 6862 & 11846 & 6862 & 11846 & 6862 & 11846 & 6862 & 11846 & 6862 \\
\hline
\end{tabular}


Table A4: Price Elasticity: Log RVUs, Log Services

\begin{tabular}{|c|c|c|c|c|c|c|c|c|}
\hline $\begin{array}{l}\text { Outcome } \\
\text { Instrument } \\
\text { Sample }\end{array}$ & $\begin{array}{c}\text { Log RVU } \\
\text { FTHHI } \\
\text { Full }\end{array}$ & $\begin{array}{c}\text { Log RVU } \\
\text { FTHHI } 05 \\
\text { Full }\end{array}$ & $\begin{array}{c}\text { Log RVU } \\
\text { FTHHI } \\
\text { Unexp. }\end{array}$ & $\begin{array}{c}\text { Log RVU } \\
\text { FTHHI } 05 \\
\text { Unexp. }\end{array}$ & $\begin{array}{c}\text { Log Serv. } \\
\text { FTHHI } \\
\text { Full }\end{array}$ & $\begin{array}{c}\text { Log Serv. } \\
\text { FTHHI } 05 \\
\text { Full }\end{array}$ & $\begin{array}{c}\text { Log Serv. } \\
\text { FTHHI } \\
\text { Unexp. }\end{array}$ & $\begin{array}{c}\text { Log Serv. } \\
\text { FTHHI } 05 \\
\text { Unexp. }\end{array}$ \\
\hline 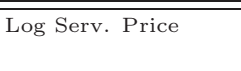 & $\begin{array}{c}1.403^{* * *} \\
(0.472)\end{array}$ & $\begin{array}{c}1.702^{* * *} \\
(0.492)\end{array}$ & $\begin{array}{l}1.314^{* *} \\
(0.549)\end{array}$ & $\begin{array}{c}1.482^{* * *} \\
(0.550)\end{array}$ & $\begin{array}{c}0.377 \\
(0.277)\end{array}$ & $\begin{array}{l}0.476^{*} \\
(0.270)\end{array}$ & $\begin{array}{c}0.321 \\
(0.314)\end{array}$ & $\begin{array}{c}0.384 \\
(0.298)\end{array}$ \\
\hline Age 41 to 45 & $\begin{array}{c}0.069 \\
(0.105)\end{array}$ & $\begin{array}{c}0.006 \\
(0.127)\end{array}$ & $\begin{array}{c}0.040 \\
(0.132)\end{array}$ & $\begin{array}{l}-0.089 \\
(0.162)\end{array}$ & $\begin{array}{c}0.015 \\
(0.060)\end{array}$ & $\begin{array}{c}0.016 \\
(0.069)\end{array}$ & $\begin{array}{c}0.009 \\
(0.075)\end{array}$ & $\begin{array}{l}-0.009 \\
(0.087)\end{array}$ \\
\hline Age 46 to 50 & $\begin{array}{l}0.160^{*} \\
(0.089)\end{array}$ & $\begin{array}{c}0.149 \\
(0.106)\end{array}$ & $\begin{array}{l}0.200^{*} \\
(0.107)\end{array}$ & $\begin{array}{c}0.195 \\
(0.130)\end{array}$ & $\begin{array}{c}0.067 \\
(0.050)\end{array}$ & $\begin{array}{c}0.076 \\
(0.058)\end{array}$ & $\begin{array}{c}0.101 \\
(0.064)\end{array}$ & $\begin{array}{c}0.122 \\
(0.075)\end{array}$ \\
\hline Age 51 to 55 & $\begin{array}{c}0.186^{* *} \\
(0.087)\end{array}$ & $\begin{array}{c}0.132 \\
(0.098)\end{array}$ & $\begin{array}{c}0.273^{* * *} \\
(0.102)\end{array}$ & $\begin{array}{l}0.189^{*} \\
(0.115)\end{array}$ & $\begin{array}{c}0.102^{* *} \\
(0.047)\end{array}$ & $\begin{array}{l}0.093^{*} \\
(0.052)\end{array}$ & $\begin{array}{c}0.153^{* * *} \\
(0.059)\end{array}$ & $\begin{array}{c}0.137^{* *} \\
(0.066)\end{array}$ \\
\hline Age 56 & $\begin{array}{c}0.097 \\
(0.120)\end{array}$ & $\begin{array}{c}0.078 \\
(0.128)\end{array}$ & $\begin{array}{c}0.228 \\
(0.155)\end{array}$ & $\begin{array}{c}0.150 \\
(0.167)\end{array}$ & $\begin{array}{c}0.044 \\
(0.063)\end{array}$ & $\begin{array}{c}0.056 \\
(0.067)\end{array}$ & $\begin{array}{c}0.093 \\
(0.082)\end{array}$ & $\begin{array}{c}0.081 \\
(0.090)\end{array}$ \\
\hline Age 57 & $\begin{array}{l}0.194^{*} \\
(0.112)\end{array}$ & $\begin{array}{c}0.129 \\
(0.129)\end{array}$ & $\begin{array}{c}0.142 \\
(0.152)\end{array}$ & $\begin{array}{c}0.028 \\
(0.184)\end{array}$ & $\begin{array}{c}0.085 \\
(0.065)\end{array}$ & $\begin{array}{c}0.085 \\
(0.072)\end{array}$ & $\begin{array}{c}0.035 \\
(0.087)\end{array}$ & $\begin{array}{c}0.032 \\
(0.104)\end{array}$ \\
\hline Age 58 & $\begin{array}{c}0.154 \\
(0.102)\end{array}$ & $\begin{array}{c}0.108 \\
(0.114)\end{array}$ & $\begin{array}{c}0.121 \\
(0.128)\end{array}$ & $\begin{array}{l}-0.058 \\
(0.157)\end{array}$ & $\begin{array}{c}0.076 \\
(0.062)\end{array}$ & $\begin{array}{l}0.097 \\
(0.067)\end{array}$ & $\begin{array}{c}0.053 \\
(0.075)\end{array}$ & $\begin{array}{c}0.011 \\
(0.089)\end{array}$ \\
\hline Age 59 & $\begin{array}{l}0.105 \\
(0.119)\end{array}$ & $\begin{array}{c}0.041 \\
(0.128)\end{array}$ & $\begin{array}{c}0.137 \\
(0.162)\end{array}$ & $\begin{array}{c}0.047 \\
(0.183)\end{array}$ & $\begin{array}{c}0.071 \\
(0.068)\end{array}$ & $\begin{array}{c}0.068 \\
(0.071)\end{array}$ & $\begin{array}{c}0.087 \\
(0.091)\end{array}$ & $\begin{array}{c}0.090 \\
(0.103)\end{array}$ \\
\hline Age 60 & $\begin{array}{c}0.224^{* *} \\
(0.100)\end{array}$ & $\begin{array}{c}0.153 \\
(0.114)\end{array}$ & $\begin{array}{c}0.194 \\
(0.125)\end{array}$ & $\begin{array}{c}0.128 \\
(0.140)\end{array}$ & $\begin{array}{l}0.126 * * \\
(0.059)\end{array}$ & $\begin{array}{l}0.113^{*} \\
(0.063)\end{array}$ & $\begin{array}{l}0.144^{*} \\
(0.076)\end{array}$ & $\begin{array}{c}0.139 \\
(0.086)\end{array}$ \\
\hline Age 61 & $\begin{array}{c}0.056 \\
(0.117)\end{array}$ & $\begin{array}{c}0.099 \\
(0.144)\end{array}$ & $\begin{array}{c}0.231 \\
(0.142)\end{array}$ & $\begin{array}{c}0.139 \\
(0.177)\end{array}$ & $\begin{array}{c}0.017 \\
(0.072)\end{array}$ & $\begin{array}{c}0.032 \\
(0.085)\end{array}$ & $\begin{array}{c}0.138 \\
(0.084)\end{array}$ & $\begin{array}{c}0.106 \\
(0.100)\end{array}$ \\
\hline Age 62 & $\begin{array}{l}0.240^{* *} \\
(0.110)\end{array}$ & $\begin{array}{c}0.195 \\
(0.128)\end{array}$ & $\begin{array}{c}0.346^{* * *} \\
(0.134)\end{array}$ & $\begin{array}{c}0.191 \\
(0.168)\end{array}$ & $\begin{array}{c}0.169^{* * *} \\
(0.055)\end{array}$ & $\begin{array}{c}0.173^{* * *} \\
(0.065)\end{array}$ & $\begin{array}{l}0.200^{* *} \\
(0.078)\end{array}$ & $\begin{array}{l}0.192^{*} \\
(0.099)\end{array}$ \\
\hline Age 63 & $\begin{array}{l}0.270^{* *} \\
(0.109)\end{array}$ & $\begin{array}{l}0.207^{*} \\
(0.124)\end{array}$ & $\begin{array}{c}0.355^{* * * *} \\
(0.136)\end{array}$ & $\begin{array}{c}0.237 \\
(0.154)\end{array}$ & $\begin{array}{c}0.167 * * * \\
(0.058)\end{array}$ & $\begin{array}{c}0.163^{* *} \\
(0.066)\end{array}$ & $\begin{array}{l}0.194^{* *} \\
(0.081)\end{array}$ & $\begin{array}{l}0.157^{*} \\
(0.094)\end{array}$ \\
\hline Male*(Age 41 to 45$)$ & $\begin{array}{c}0.096 \\
(0.113)\end{array}$ & $\begin{array}{c}0.126 \\
(0.135)\end{array}$ & $\begin{array}{c}0.146 \\
(0.144)\end{array}$ & $\begin{array}{c}0.256 \\
(0.174)\end{array}$ & $\begin{array}{c}0.022 \\
(0.064)\end{array}$ & $\begin{array}{c}0.010 \\
(0.073)\end{array}$ & $\begin{array}{c}0.006 \\
(0.081)\end{array}$ & $\begin{array}{c}0.025 \\
(0.093)\end{array}$ \\
\hline Male*(Age 46 to 50 ) & $\begin{array}{l}-0.024 \\
(0.101)\end{array}$ & $\begin{array}{l}-0.045 \\
(0.115)\end{array}$ & $\begin{array}{l}-0.049 \\
(0.119)\end{array}$ & $\begin{array}{l}-0.070 \\
(0.140)\end{array}$ & $\begin{array}{l}-0.055 \\
(0.055)\end{array}$ & $\begin{array}{l}-0.071 \\
(0.062)\end{array}$ & $\begin{array}{l}-0.097 \\
(0.071)\end{array}$ & $\begin{array}{l}-0.122 \\
(0.081)\end{array}$ \\
\hline Male*(Age 51 to 55 ) & $\begin{array}{l}-0.016 \\
(0.099)\end{array}$ & $\begin{array}{c}0.028 \\
(0.110)\end{array}$ & $\begin{array}{l}-0.091 \\
(0.117)\end{array}$ & $\begin{array}{l}-0.024 \\
(0.130)\end{array}$ & $\begin{array}{l}-0.056 \\
(0.054)\end{array}$ & $\begin{array}{l}-0.047 \\
(0.058)\end{array}$ & $\begin{array}{c}-0.117^{*} \\
(0.067)\end{array}$ & $\begin{array}{l}-0.094 \\
(0.074)\end{array}$ \\
\hline Male*(Age 56$)$ & $\begin{array}{c}0.026 \\
(0.131)\end{array}$ & $\begin{array}{c}0.026 \\
(0.140)\end{array}$ & $\begin{array}{l}-0.045 \\
(0.174)\end{array}$ & $\begin{array}{c}0.051 \\
(0.187)\end{array}$ & $\begin{array}{l}-0.017 \\
(0.069)\end{array}$ & $\begin{array}{l}-0.034 \\
(0.074)\end{array}$ & $\begin{array}{l}-0.065 \\
(0.093)\end{array}$ & $\begin{array}{l}-0.034 \\
(0.100)\end{array}$ \\
\hline Male*(Age 57) & $\begin{array}{c}0.053 \\
(0.126)\end{array}$ & $\begin{array}{l}0.045 \\
(0.139)\end{array}$ & $\begin{array}{c}0.063 \\
(0.168)\end{array}$ & $\begin{array}{c}0.112 \\
(0.195)\end{array}$ & $\begin{array}{c}0.006 \\
(0.074)\end{array}$ & $\begin{array}{l}-0.017 \\
(0.080)\end{array}$ & $\begin{array}{l}0.018 \\
(0.095)\end{array}$ & $\begin{array}{l}0.008 \\
(0.108)\end{array}$ \\
\hline Male*(Age 58) & $\begin{array}{c}0.041 \\
(0.115)\end{array}$ & $\begin{array}{c}0.053 \\
(0.124)\end{array}$ & $\begin{array}{c}0.041 \\
(0.145)\end{array}$ & $\begin{array}{c}0.189 \\
(0.164)\end{array}$ & $\begin{array}{c}0.013 \\
(0.069)\end{array}$ & $\begin{array}{l}-0.018 \\
(0.073)\end{array}$ & $\begin{array}{c}0.020 \\
(0.084)\end{array}$ & $\begin{array}{c}0.056 \\
(0.094)\end{array}$ \\
\hline Male*(Age 59) & $\begin{array}{c}0.036 \\
(0.132)\end{array}$ & $\begin{array}{c}0.057 \\
(0.143)\end{array}$ & $\begin{array}{l}-0.019 \\
(0.180)\end{array}$ & $\begin{array}{c}0.014 \\
(0.203)\end{array}$ & $\begin{array}{l}-0.042 \\
(0.077)\end{array}$ & $\begin{array}{l}-0.069 \\
(0.081)\end{array}$ & $\begin{array}{l}-0.104 \\
(0.107)\end{array}$ & $\begin{array}{l}-0.141 \\
(0.120)\end{array}$ \\
\hline Male*(Age 60) & $\begin{array}{l}-0.009 \\
(0.114)\end{array}$ & $\begin{array}{c}0.038 \\
(0.125)\end{array}$ & $\begin{array}{c}0.050 \\
(0.139)\end{array}$ & $\begin{array}{c}0.099 \\
(0.148)\end{array}$ & $\begin{array}{l}-0.063 \\
(0.066)\end{array}$ & $\begin{array}{l}-0.053 \\
(0.069)\end{array}$ & $\begin{array}{l}-0.092 \\
(0.085)\end{array}$ & $\begin{array}{l}-0.074 \\
(0.093)\end{array}$ \\
\hline Male*(Age 61) & $\begin{array}{c}0.075 \\
(0.132)\end{array}$ & $\begin{array}{c}0.026 \\
(0.160)\end{array}$ & $\begin{array}{l}-0.111 \\
(0.172)\end{array}$ & $\begin{array}{l}-0.030 \\
(0.211)\end{array}$ & $\begin{array}{c}0.018 \\
(0.079)\end{array}$ & $\begin{array}{c}0.009 \\
(0.094)\end{array}$ & $\begin{array}{l}-0.131 \\
(0.100)\end{array}$ & $\begin{array}{l}-0.100 \\
(0.118)\end{array}$ \\
\hline Male*(Age 62) & $\begin{array}{l}-0.039 \\
(0.127)\end{array}$ & $\begin{array}{c}0.011 \\
(0.148)\end{array}$ & $\begin{array}{l}-0.218 \\
(0.163)\end{array}$ & $\begin{array}{l}-0.030 \\
(0.201)\end{array}$ & $\begin{array}{l}-0.105^{*} \\
(0.064)\end{array}$ & $\begin{array}{l}-0.108 \\
(0.075)\end{array}$ & $\begin{array}{c}-0.199 * * \\
(0.096)\end{array}$ & $\begin{array}{l}-0.176 \\
(0.119)\end{array}$ \\
\hline Male*(Age 63) & -0.062 & -0.062 & -0.215 & -0.125 & -0.051 & -0.080 & -0.150 & -0.127 \\
\hline
\end{tabular}




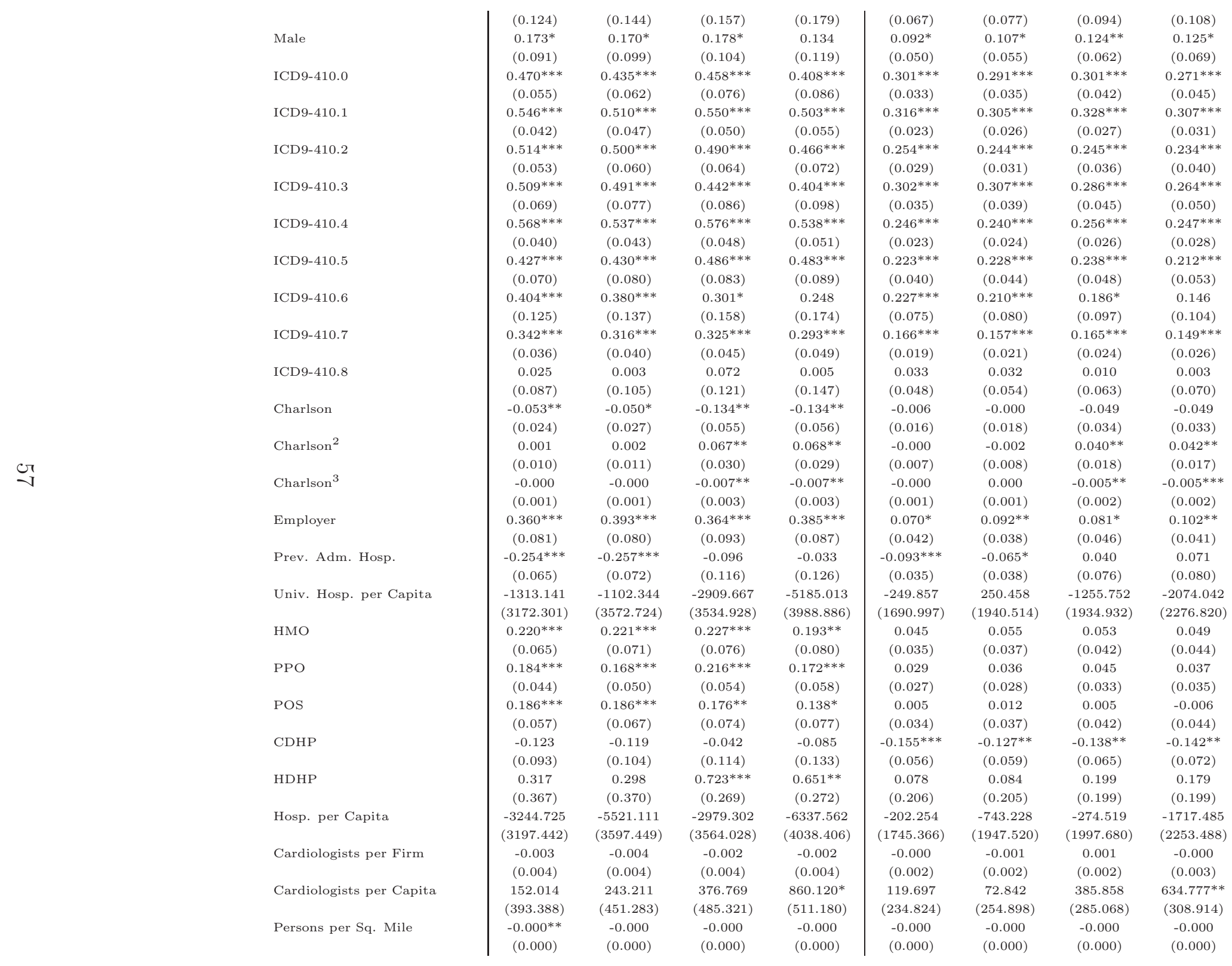




\begin{tabular}{l|cccc|cccc} 
Log Med. Inc. & 0.162 & 0.122 & 0.195 & 0.139 & 0.112 & 0.110 & 0.158 & 0.131 \\
& $(0.182)$ & $(0.212)$ & $(0.202)$ & $(0.229)$ & $(0.102)$ & $(0.113)$ & $(0.112)$ & $(0.127)$ \\
Log Hosp. Costs per Emp & -0.030 & -0.061 & -0.043 & -0.087 & 0.015 & 0.008 & -0.010 & -0.025 \\
& $(0.041)$ & $(0.049)$ & $(0.050)$ & $(0.056)$ & $(0.023)$ & $(0.027)$ & $(0.028)$ & $(0.032)$ \\
Log Med. Rent & 0.319 & 0.391 & 0.229 & 0.305 & 0.119 & 0.096 & 0.058 & 0.048 \\
& $(0.267)$ & $(0.308)$ & $(0.302)$ & $(0.325)$ & $(0.153)$ & $(0.163)$ & $(0.168)$ & $(0.175)$ \\
Log Med. House Val. & -0.165 & -0.179 & -0.165 & -0.148 & -0.008 & -0.009 & 0.009 & 0.041 \\
& $(0.134)$ & $(0.156)$ & $(0.148)$ & $(0.165)$ & $(0.078)$ & $(0.086)$ & $(0.084)$ & $(0.090)$ \\
Frac. Heavy Smokers & -0.816 & -0.893 & -0.722 & -0.893 & -0.318 & -0.365 & -0.304 & -0.460 \\
& $(0.580)$ & $(0.650)$ & $(0.711)$ & $(0.730)$ & $(0.356)$ & $(0.371)$ & $(0.386)$ & $(0.380)$ \\
Frac. Obese & -0.713 & -0.686 & -0.739 & -0.341 & 0.160 & 0.104 & 0.429 & $0.595^{*}$ \\
& $(0.481)$ & $(0.556)$ & $(0.604)$ & $(0.645)$ & $(0.263)$ & $(0.294)$ & $(0.320)$ & $(0.337)$ \\
Treated Prevalence (non-card) & $0.584^{* *}$ & 0.443 & $0.697^{* *}$ & $0.584^{*}$ & 0.172 & 0.148 & 0.207 & 0.153 \\
& $(0.263)$ & $(0.305)$ & $(0.294)$ & $(0.312)$ & $(0.137)$ & $(0.152)$ & $(0.142)$ & $(0.153)$ \\
Serv. Util. Index (non card) & -0.561 & -0.844 & -0.251 & -0.506 & -0.331 & -0.377 & 0.034 & -0.057 \\
& $(0.473)$ & $(0.544)$ & $(0.565)$ & $(0.634)$ & $(0.273)$ & $(0.293)$ & $(0.334)$ & $(0.349)$ \\
Observations & 11846 & 9836 & 6862 & 5739 & 11846 & 9836 & 6862 & 5739
\end{tabular}

